SNF-10618

Revision 0

\title{
Spent Nuclear Fuel Project Canister Storage Building Multi-Canister Overpack Sampling System Validation (OCRWM)
}

Prepared for the U.S. Department of Energy

Assistant Secretary for Environmental Management

\section{Fluor Hanford}

P.O. Box 1000

Richland, Washington

Contractor for the U.S. Department of Energy

Richland Operations Office under Contract BE-AC06-96RL13200 
SNF-10618

Revision 0

\section{Spent Nuclear Fuel Project Canister Storage Building Multi-Canister Overpack Sampling System Validation (OCRWM)}

DM Black

MJ Klem

Prepared for the U.S. Department of Energy

Assistant Secretary for Environmental Management

\section{Fluor Hanford}

P.O. Box 1000

Richland, Washington

Contractor for the U.S. Department of Energ

Richland Operations Office under Contract DE-AC06-96RL13200

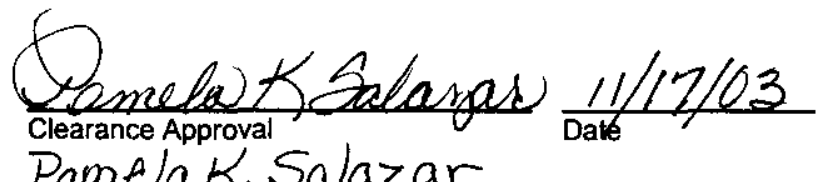

Pamela K. Salazar
Fluor Federal Services

COGEMA Engineering Corporation 


\begin{tabular}{|l|l|}
\hline \multicolumn{2}{|c|}{ EDC For use with Technical Documents (when appropriate) } \\
\hline EDC- HNF-EMP-03-14862 /73/2 ZMB & FMP- \\
\hline EDT- & ECN- \\
\hline Project No.: $\quad$ W-379 & Division: SNF Proj. \\
\hline Document Type: RPT & Page Count: 152 \\
\hline
\end{tabular}

\begin{tabular}{|l|l|l|l|l|l|}
\hline \multicolumn{7}{|c|}{ For use with Speeches, Articles, or Presentations (when appropriate) } \\
\hline \multicolumn{1}{|c|}{ Abstract } & & Summary & & Full Paper & \\
\hline Conference Name: & & & \\
\hline Conference Date: & & & \\
\hline Conference Location: & & \\
\hline Conference Sponsor: & & \\
\hline Published in: & & \\
\hline Publication Date: & & \\
\hline
\end{tabular}

\section{LEGAL DISCLAIMER}

This report was prepared as an account of work sponsored by an agency of the United States Government. Neither the United States Government nor any agency thereof, nor any of their employees, nor any of their contractors, subcontractors or their employees, makes any warranty, express or implied, or assumes any legal liability or responsibility for the accuracy, completeness, or any third party's use or the results of such use of any information, apparatus, product, or process disclosed, or represents that its use would not infringe privately owned rights. Reference herein to any specific commercial product, process, or service by trade name, trademark, manufacturer, or otherwise, does not necessarily constitute or imply its endorsement, recommendation, or favoring by the United States Government or any agency thereof or its contractors or subcontractors. The views and opinions of authors expressed herein do not necessarily state or reflect those of the United States Government or any agency thereof.

Scientiflc or technical information is available to U.S. Government and U.S. Government contractor personnel through the Office of Scientific and Technical information (OSTI). it is available to others through the National Technical information Service (NTIS).

This report has been reproduced from the best available copy. 


\section{TABLE OF CONTENTS}

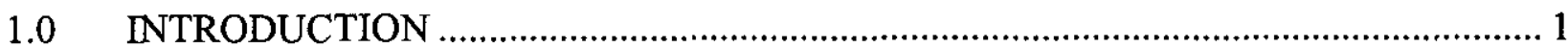

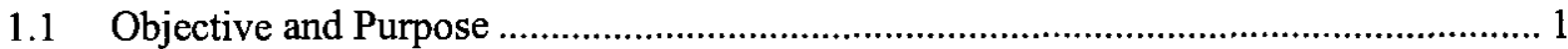

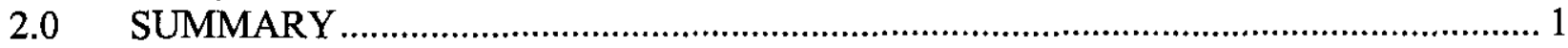

3.0 SAMPLING PROCESS TEST RESULTS .............................................................. 2

4.0 DESCRIPTION OF GAS SAMPLING SYSTEM ……............................................. 5

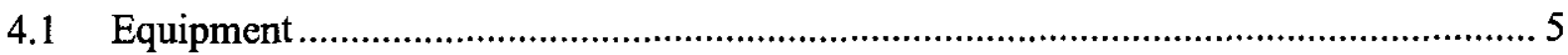

4.1.1 MCO Sampling/Weld Station ....................................................................... 5

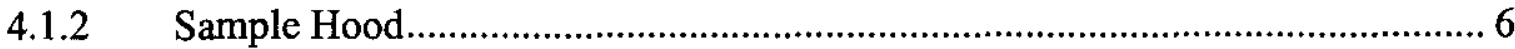

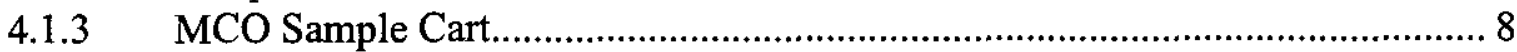

4.1.4 Interface Manifold ……………..................................................................

4.1.5 Helium Supply System ................................................................................. 9

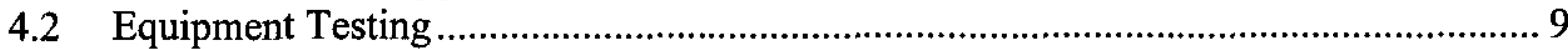

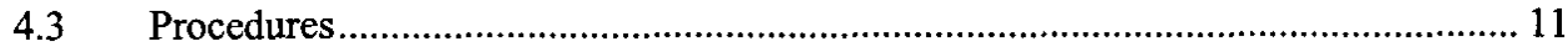

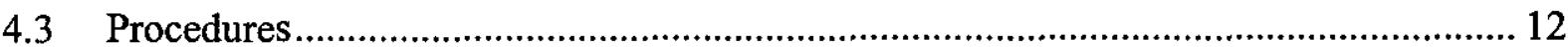

4.3.1 Work Package .......................................................................................... 12

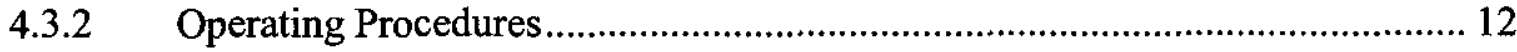

4.3.3 Maintenance Procedures ........................................................................... 12

4.3.4 Sample Control and Laboratory Analysis Procedures ....................................... 13

4.3.5 MCO Sampling Process .............................................................................. 14

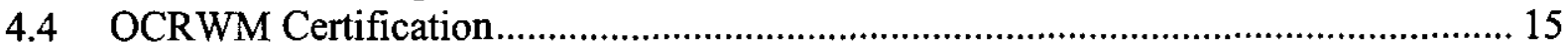

4.4.1 MCO Sample Cart Pressure Indicating Transmitter ............................................ 16

4.4.2 MCO Sample Cart Temperature Element and Transmitter ............................... 16

4.4.3 Helium Gas Supply ................................................................................... 17

4.4.4 Gas Sample Canisters ................................................................................. 18

4.5 Analysis of Gas Samples ………………............................................................ 18

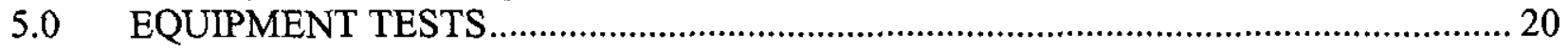

$5.1 \quad$ MCO Sample Cart.............................................................................................. 20

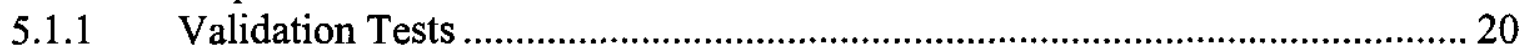

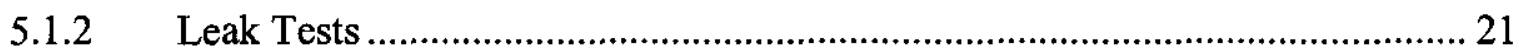

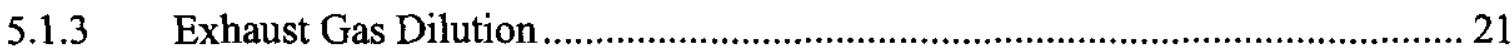

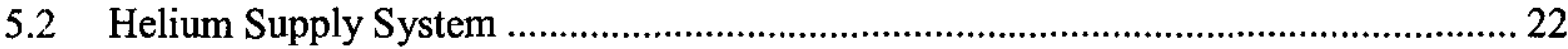

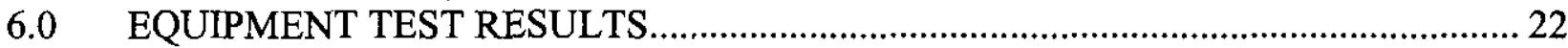

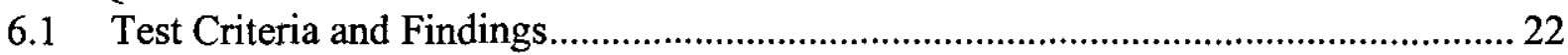

6.1.1 Helium Purity ......................................................................................... 22

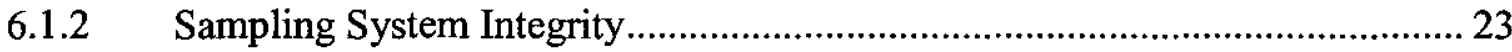

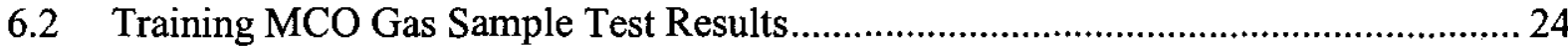

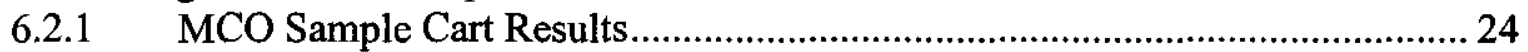

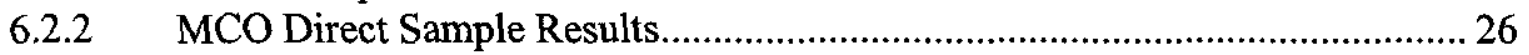

6.2.3 Estimated MCO Gas Correlation Factors ……….......................................... 26

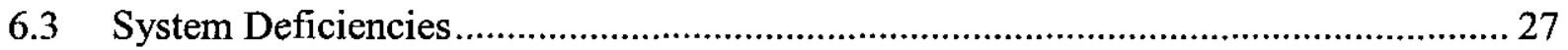

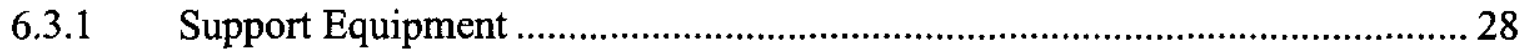

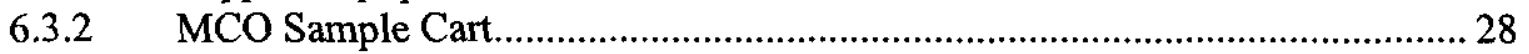

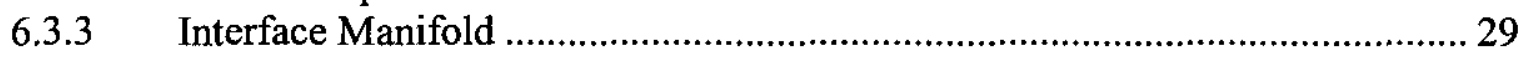

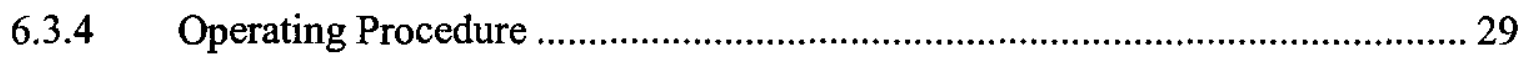

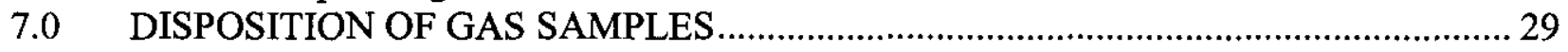

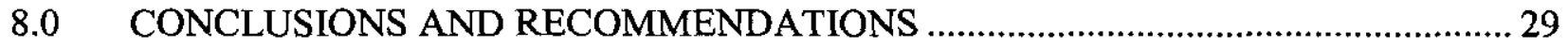

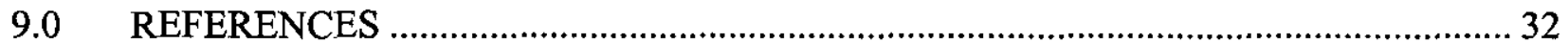




\section{LIST OF FIGURES}

Figure 2-1

Figure 3-1

Figure 3-2

Figure 3-3

Figure 3-4

Figure A-1
Simplified Schematic Diagram of MCO Gas Sampling System

Sample Hood BARR-002 Illustration

MCO Sampling CART-001 Illustration

Sample Interface for CART-001

MCO Helium Supply System (GBM-5) Illustration

MCO Sample Cart
2

6

7

10

11

A-3

\section{LIST OF TABLES}

Table 3-1 Maintenance Procedures for MCO Gas Sample Training and

Table 3-2

Validation Testing

Table 3-3

Critical Characteristics and Verification Methods PIT-721

Critical Characteristics and Verification Methods for TE/TIT-723 16

Table 3-4

Critical Characteristics and Verification of Monitored MCO Helium

17

Table 3-5

Gas Sample Analysis and Precision Requirements

Table 5-1

Acceptance Criteria and Laboratory Results of Helium Blank Samples

Table 5-2

Training MCO Gas Sample Results Based on Conventional Usage of Sample Cart

Table 5-3 Training MCO Gas Sample Results Based on Direct Samples

Table 5-4 Correlation Factors for MCO Gas Sampling

Table A-1 Sample Results Helium Blank Major Constituents and Residual $\quad$ A-4

Table A-2 Residual Helium Blank Only Valve Positions

A-4
Table A-3 Initial Valve Positions for Residual Blank Helium and Training MCO Gas

A-4

Table A-4 Residual Blank Helium and Training MCO Gas In Head End of

A-4 Sample Cart with Valve MCO-V-151 Closed

Table A-5 Final Valve Positions for Residual Blank Helium and Training MCO Gas

Table A-6 Residual Blank Helium and Training MCO Gas In Sample Cart

Table A-7 Sample Results Residual Helium Blank and Training MCO Gas Major Constituents

Table A-8 Training MCO Gas Composition Based on Direct Sampling Method

Table A-9 Major Constituent Correlation Factors

Table A-10 Void Volume of Training MCO Based on Ideal Gas Law

\section{APPENDIXES}

Appendix A Summary of Sampling Process Calculations 


\section{LIST OF TERMS}

$\begin{array}{ll}\text { ALARA } & \text { As Low As Reasonably Achievable } \\ \text { CSB } & \text { Canister Storage Building } \\ \text { DCS } & \text { Distributive Control System } \\ \text { HEPA } & \text { High Efficiency Particular Air } \\ \text { MCO } & \text { Multi-canister Overpack } \\ \text { MHM } & \text { Multi-canister Overpack Handling Machine } \\ \text { MP } & \text { Maintenance Procedure } \\ \text { N/A } & \text { Not Available } \\ \text { OCRWM } & \text { Office of Civilian Radioactive Waste Management } \\ \text { PAT } & \text { Preoperational Acceptance Test } \\ \text { PCV } & \text { Pressure Control Valve } \\ \text { PIC } & \text { Pressure Indicating Control } \\ \text { PIT } & \text { Pressure Indicating Transmitter } \\ \text { PNNL } & \text { Pacific Northwest National Laboratory } \\ \text { PS } & \text { Process Standard } \\ \text { QA } & \text { Quality Assurance } \\ \text { QARD } & \text { Quality Assurance Requirements Descriptions } \\ \text { RTU } & \text { Remote Terminal Unit } \\ \text { SCF } & \text { Sample Correlation Factor } \\ \text { TCF } & \text { Theoretical Correlation Factor } \\ \text { SNF } & \text { Spent Nuclear Fuel } \\ \text { SP } & \text { Surveillance Procedure } \\ \text { THC } & \text { Total Hydrocarbon } \\ \text { TIT } & \text { Temperature Indicating Transmitter } \\ \text { TPCR } & \text { Technical Procedure Change Request } \\ \text { TSR } & \text { Technical Safety Requirement } \\ \text { WP } & \text { Work Package } \\ & \end{array}$




\subsection{INTRODUCTION}

Approximately 400 Multi-canister overpacks (MCO) containing spent nuclear fuel are to be interim stored at the Canister Storage Building (CSB). Several MCOs (monitored MCOs) are designated to be gas sampled periodically at the CSB sampling/weld station (Bader 2002a). The monitoring program includes pressure, temperature and gas composition measurements of monitored MCOs during their first two years of interim storage at the CSB.

The MCO sample cart (CART-001) is used at the sampling/weld station to measure the monitored $\mathrm{MCO}$ gas temperature and pressure, obtain gas samples for laboratory analysis and refill the monitored $\mathrm{MCO}$ with high purity helium as needed. The sample cart and support equipment were functionally and operationally tested and validated before sampling of the first monitored $\mathrm{MCO}(\mathrm{H}-036)$. This report documents the results of validation testing using training MCO (TR-003) at the CSB. Another report (Bader 2002b) documents the sample results from gas sampling of the first monitored MCO (H-036).

\subsection{Objective and Purpose}

This document is required by Spent Nuclear Project Testing Process Administrative Procedure (FH 2000). It verifies that the MCO sample cart and support equipment perform as designed and demonstrates satisfactory performance for continued service.

The objectives of MCO gas sampling are:

- Obtain representative samples from monitored MCOs during their first two years of interim storage at the CSB

- Minimize sampling error as practical

- Meet MCO safety and quality requirements including:

- Maintain adequate MCO gas pressure

- Prevent introduction of contaminants into an MCO

\subsection{SUMMARY}

Validation testing of the MCO gas sampling system showed the equipment and procedure as originally constituted will satisfactorily sample the first monitored MCO. Subsequent system and procedural improvements will provide increased flexibility and reliability for future MCO gas sampling.

The physical operation of the sampling equipment during testing provided evidence that theoretical correlation factors for extrapolating MCO gas composition from sample results are unnecessarily conservative. Empirically derived correlation factors showed adequate conservatism and support use of the sample system for ongoing monitored MCO sampling. 


\subsection{SAMPLING PROCESS TEST RESULTS}

The main features of the sampling system are represented in Figure 3-1. These features are the MCO in the sample/weld pit, sample system, Office of Civil Radioactive Waste Management (OCRWM) helium supply, and the sample hood exhaust system.

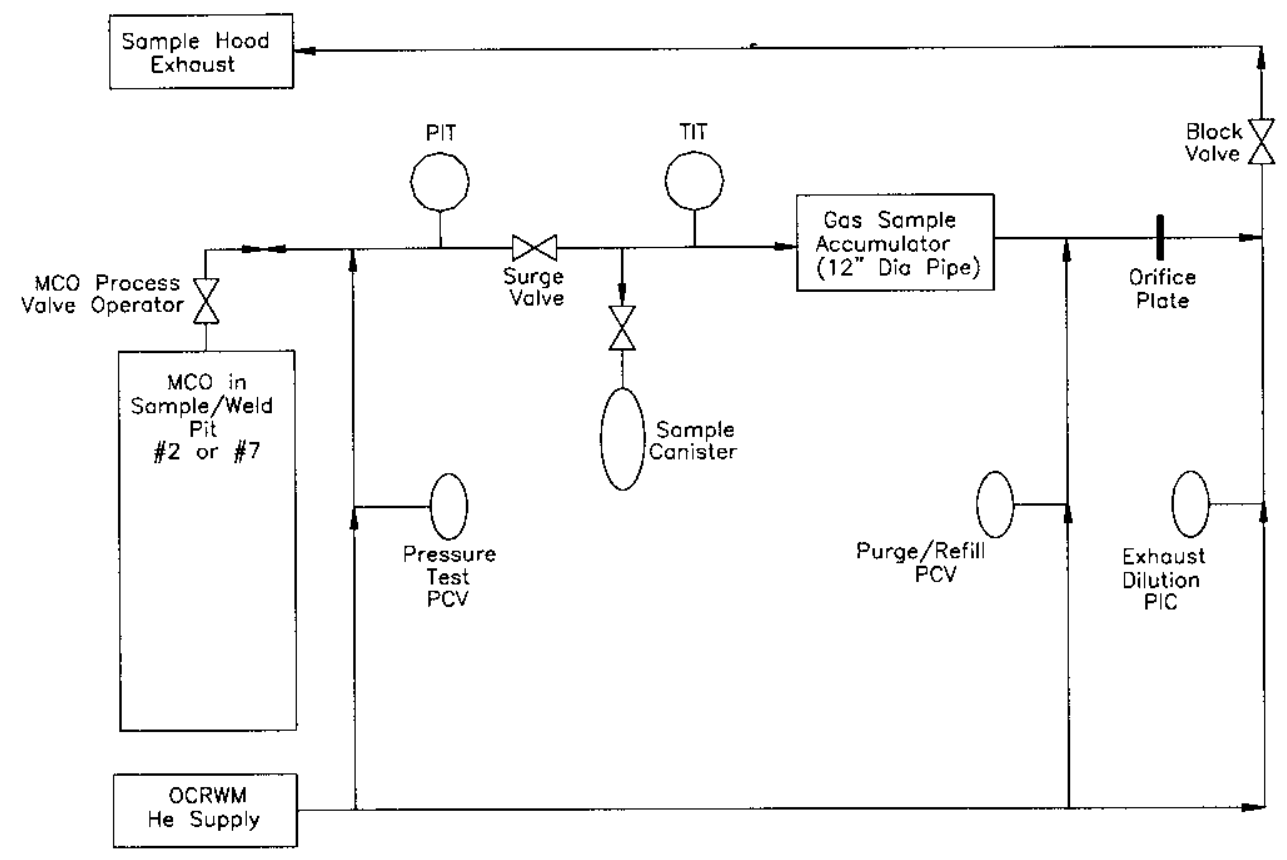

Figure 3-1: Simplified Schematic Diagram of MCO Gas Sampling System

Operating procedure OP-23-002S Operate MCO Sample Station (OCRWM) is used to obtain a sample of MCO gas. This sample includes residual helium from pressure testing and purging of the sampling system. The residual helium is accounted for in order to understand the actual MCO gas composition.

The sampling equipment contains residual helium at close to atmospheric pressure (about 15 psia) prior to accessing gas via the MCO process valve. MCO gas flows into the sample accumulator and increases the pressure in the cart by about 10 psi to a final pressure of about 25 psia. The resulting inventory is a combination of residual helium ( $>99.5 \%$ pure) and gas from the MCO. The MCO gas is about $10 / 25$ or $2 / 5$ of the cart's gas inventory; residual helium makes up the other $3 / 5$-gas inventory. The 10 psi pressure increase and MCO gas dilution by the residual gas in the sampling system results in a theoretical correlation factor (TCF) of about 2.5. The actual TCF varies in accordance with actual MCO and cart system pressures. 
An equation relating gas pressures and concentrations can be developed based on Dalton's Law. Equation 1 relates the final pressure of the sampling system to the sum of the residual pressure of the system before addition of gas from the $\mathrm{MCO}$, and the pressure change resulting from addition of the MCO gas.

$P_{f}=P_{r}+\Delta P_{m c o}$

$\Delta P_{\text {mco }}=P_{f}-P_{r}$

where :

$\mathrm{P}_{\mathrm{f}}=$ final pressure of sample system at equilibrium, psia

$\mathrm{P}_{\mathrm{r}}=$ residual pressure of sample system before addition of $\mathrm{MCO}$ gas, psia

$\Delta \mathrm{P}_{\mathrm{mco}}=$ pressure increase of sampling system by $\mathrm{MCO}$ gas, $\mathrm{psi}$

The partial pressure of a constituent is related to the mole fraction and the gas pressure as shown in Equation 3.

$\mathrm{y}_{\mathrm{f}} \mathrm{P}_{\mathrm{f}}=\mathrm{y}_{\mathrm{r}} \mathrm{P}_{\mathrm{r}}+\mathrm{y}_{\mathrm{mco}} \Delta \mathrm{P}_{\mathrm{mco}}=\mathrm{y}_{\mathrm{r}} \mathrm{P}_{\mathrm{r}}+\mathrm{y}_{\mathrm{mco}}\left(\mathrm{P}_{\mathrm{f}}-\mathrm{P}_{\mathrm{r}}\right)$

where:

$\mathrm{y}_{\mathrm{f}}=$ mole fraction of any constituent in sample system at equilibrium $=$ [Sample Result]

$\mathrm{y}_{\mathrm{r}}=$ mole fraction of any constituent in residual gas before addition of MCO gas

$\mathrm{y}_{\mathrm{mco}}=$ mole fraction of any constituent in $\mathrm{MCO}$ gas $=[\mathrm{MCO}]$

Equation 3 is rearranged and solved for the mole fraction or concentration of any constituent in the $\mathrm{MCO}$ at equilibrium.

$y_{\text {mco }}\left(P_{f}-P_{r}\right)=y_{f} P_{f}-y_{r} P_{r}$

$y_{\text {mco }}=\left(y_{f} P_{f}-y_{r} P_{r}\right) /\left(P_{f}-P_{r}\right)$

The pressure testing and purging of the sampling system with $>99.5 \%$ helium reduces the impurity content $\left(\mathrm{y}_{\mathrm{r}}\right)$ in the sampling system to negligible values before addition of MCO gas. The negligible impurity values simplify Equation 4 to the below equation.

$y_{m c o}=\left(y_{f}\right) P_{f} /\left(P_{f}-P_{r}\right)$

The TCF is related to the pressure changes of the sampling system as discussed above and shown by Equation 6.

$\mathrm{TCF}=\mathrm{P}_{\mathrm{f}} /\left(\mathrm{P}_{\mathrm{f}}-\mathrm{P}_{\mathrm{r}}\right)$

Combining Equation 5 and Equation 6 gives the following equation for calculation of the MCO gas concentration after perfect mixing of the residual helium gas and added MCO gas in the sampling system.

$\mathrm{y}_{\mathrm{mco}}=\left(\mathrm{y}_{\mathrm{f}}\right)(\mathrm{TCF})=[\mathrm{MCO}]=[$ Sample Result $](\mathrm{TCF})$ 
Table 3-1 lists example conditions and calculated values for TCF and MCO gas concentrations at perfect mixing equilibrium based on the hydrogen concentration.

Table 3-1 Calculated Values of TCF and MCO Hydrogen Concentration at Equilibrium

\begin{tabular}{|c|c|c|c|c|}
\hline $\begin{array}{c}\text { Residual } \\
\text { Pressure Sample } \\
\text { System } \\
\mathrm{P}_{\mathrm{r}}\end{array}$ & $\begin{array}{c}\text { Equilibrium Pressure } \\
\text { After MCO Gas Addition } \\
\mathrm{P}_{\mathrm{f}}\end{array}$ & $\mathrm{TCF}$ & $\begin{array}{c}\text { Hydrogen } \\
\text { Concentration at } \\
\text { Equilibrium Pressure } \\
\text { [Sample Result] }\end{array}$ & $\begin{array}{c}\text { Calculated } \\
\text { Hydrogen } \\
\text { Concentration } \\
\text { [MCO] }\end{array}$ \\
\hline $\mathrm{psia}$ & $\mathrm{psia}$ & - & $\mathrm{ppm}$ & $\mathrm{ppm}$ \\
\hline 15 & 26 & 2.36 & 10 & 23.6 \\
\hline 15 & 25 & 2.50 & 10 & 25 \\
\hline 15 & 24 & 2.67 & 10 & 26.7 \\
\hline
\end{tabular}

Even though a TCF of about 2.5 can be seen to represent the expected pressure changes during MCO sampling and assuming perfect mixing, validation test results show that the sample drawn matched quite closely the actual MCO gas concentration. This result implies that the residual $\mathrm{He}$ was pushed from the sample system piping into the downstream accumulator by the inrush of MCO gas and that the sample was drawn before the gasses in the system were fully mixed. Application of a TCF is, therefore, very conservative. Complete gas mixing in a short period of time is seriously retarded by the presence of the $1 / 8$ " pipe $T$ that houses the thermocouple (TE723) just upstream of the gas accumulator and downstream of the sample take-off connection. This restriction provides a reasonable explanation for the close agreement between the actual MCO gas concentration and the sample from the cart.

Because the TCF is too conservative, a more useful sample-based correlation factor (SCF) relating the results from sample cart samples and direct samples of training $\mathrm{MCO}$ gas was developed for several major gas constituents. The average SCF was about 1.15 for argon, carbon dioxide, nitrogen and oxygen and 1.00 for helium. The SCF for oxygen was 1.14. These empirically derived SFCs reflect the close match between directly sampled MCO gas and sample cart samples.

The procedure used for sampling of the training MCO does not ensure complete mixing of the gas in the sample cart. The surge valve is left open allowing communication between the MCO and sampling system until equilibrium pressure is achieved after about thirty seconds. It is postulated that the movement of $\mathrm{MCO}$ gas through the sample system piping carries the purge He out of the smaller diameter piping and into the downstream gas accumulator. The sample was drawn a few minutes after closure of the surge valve allowing limited time for diffusion to equilibrate the concentration between the surge valve and block valve (see Figure 3-1). The sampling procedure must be performed so as to minimize the time between MCO process valve opening and sample bottle filling to eliminate uncertainty in results of future samples. Changes in the design of the sampling system hardware could also reduce sampling uncertainty. Additional tests using the training MCO to improve understanding of the plug flow and slow mixing behavior in the cart could also be performed. Samples could be taken after set time periods to determine the rate at which mixing occurs and procedure changes suggested by test results could improve sampling accuracy. 
Several possible improvements were suggested during testing; they include both hardware and procedural changes. Suggested equipment upgrades included modifications of the helium gas supply, MCO sample cart valving, and interface manifold connections. Improvements to the sampling procedure, OP-23-002S, include changes to reflect hardware upgrades and replacement, provision for performing certain steps in parallel (reduces time to complete sampling), and increased time for helium purging of air from the MCO sample cart piping. Extensive redesign/new design of the sampling equipment to greatly reduce the volume of gas taken from an MCO has also been suggested.

\subsection{DESCRIPTION OF GAS SAMPLING SYSTEM}

The MCO gas sampling system and support equipment are described in the following sections. The discussion includes equipment, equipment testing, procedures, OCRWM considerations and sample analysis. Each is discussed in some detail.

\subsection{Equipment}

The gas sampling equipment consists of two sampling/weld stations, an MCO sample hood, the sample hood exhaust system, MCO sample cart, sample interface manifold, and helium supply system.

\subsubsection{MCO Sampling/Weld Station}

The MCO Sampling/Weld Station System is used to sample gas from monitored MCOs and to weld a Canister Cover Assembly to each MCO. The MCO Handling Machine (MHM) is used to transport the designated MCO from the cask-receiving pit or storage tube to a sampling/weld station pit located at the south end of the CSB operating deck and back from the sampling/weld pit to the designated storage tube. The major components of the sampling/weld station are:

- Two radiation shielded Sampling/Weld Station Pits (Pits \#2 and \#7) with impact absorbers and two support utilities pits (Pits \#3 and \#6) are provided for sampling and welding operations. Impact absorbers prevent damage to the MCOs upon placement in the Sampling/Weld Stations in the unlikely drop of the MCO from the MHM. Pits \#2 and \#7 have removable guardrails to protect personnel against accidental falls. Pits \#3 and \#6 are covered with removable steel grating.

- Two 7.5-ton capacity gantry cranes, one for each of the two stations are used to position the Sample Hood (one Sample Hood to be shared between the two stations). Each gantry crane is equipped with one 5.0 ton and two 1.0 ton hoists.

- Temporary shielding is used to protect operating personnel against radiation streaming during MCO movement into or out of the sampling/weld pits. The shielding reduces the radiation dose rate to within as low as reasonably achievable (ALARA) limits. 
- Fixed shielding with internal coolant circulation and MCO cooling caps (at each station) is used to cool any high temperature MCO top section for operator safety during sampling or welding.

- A shared, permanently installed Sampling/Weld station high efficiency particular air (HEPA) filter/exhauster is provided to ventilate the sample and/or weld hoods (AH-006).

- A sample cart, connected to the sample hood process gas HEPA filter provides equipment for gas sampling and MCO refill operations (CART-001).

- An interface manifold is used to obtain gas samples for laboratory analysis. The interface manifold is connected to the sample cart.

Additional support equipment includes a fixed optical pyrometer at each station to measure the MCO skin temperature for a general temperature profile; a hand-held pyrometer to measure the temperature of the $\mathrm{MCO}$ shield plug; one process valve operator for MCO gas access, tools for opening/closing the $\mathrm{MCO}$ process port valve and cover plate removal/installation, and non destructive examination equipment to test integrity of the MCO Port \#2 cover plate seal after gas sampling.

\subsubsection{Sample Hood}

Sample Hood (BARR-002) fulfills several functions: it provides confinement of any release of the MCO's internal atmosphere thereby preventing a release into the CSB operating area atmosphere during sampling operations; confines the exhaust from the Sample Cart; and provides a seismically secure mounting location for the high efficiency particulate air (HEPA) filter FH-9. The sample hood is stainless steel and has an open bottom, two glove ports, equipment pass through port, view windows, exterior lighting, ventilation control damper, and sample hose with valve operator and accessories. Figure 4-1 shows a schematic illustration of the sample hood and support equipment. See drawing H-2-120400 for additional details.

A valve operator with 1-inch diameter flexible hose connects the $\mathrm{MCO}$ port \#2 (after port cover removal) to the HEPA filter FH-9. FH-9 removes particulate contamination that may pass through the internal MCO HEPA (not testable) from the MCO sample gas before the gas exits the sample hood and enters another 1-inch diameter flexible hose that connects to the sample cart. A 1-1/2 inch diameter flexible hose is used to route exhaust gas from the sample cart to the sample hood exhaust line. Confinement is accomplished by maintaining a negative pressure within the sample hood so that any airflow is from the operating area into the sample hood. Air is exhausted from the sample hood to the building ventilation system through a HEPA filtered unit CSB-AH-006. 


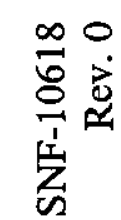

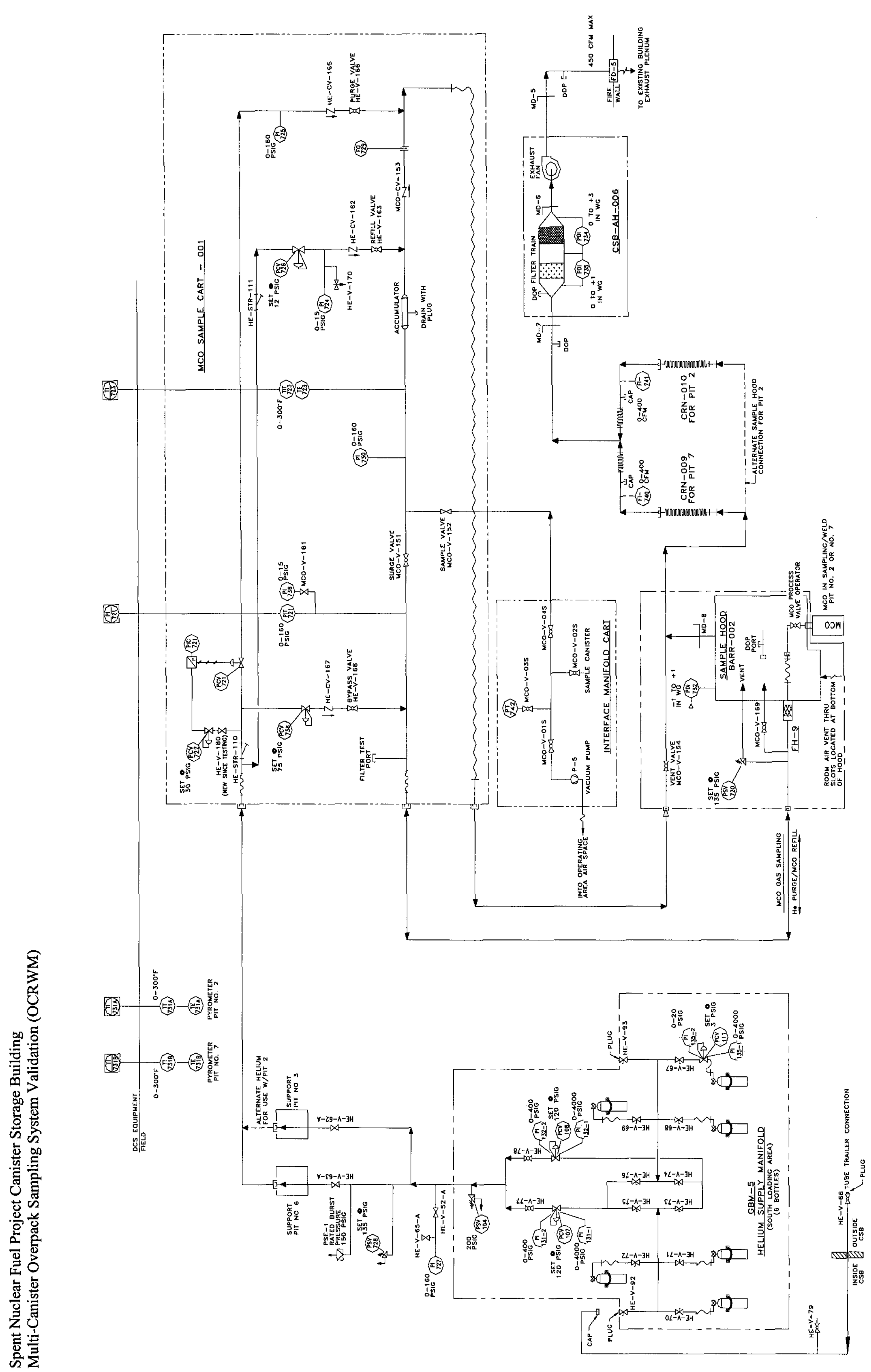


HEPA filter FH-9 is constructed of stainless steel and contains a sinter bonded and reinforced composite filter. HEPA Filter FH-9 is challenge testable in-place. The sample hood gloves and pass through port were upgraded to address operational enhancements before validation testing (Black and McClellan 2001).

\subsubsection{MCO Sample Cart}

The MCO Sample Cart (CART-001) is a pushcart with piping, valves, fittings, flexible hose with quick connects, instrumentation, and gas accumulator. The cart connects to the 120-psig-helium supply, distributive control system (DCS) via a remote terminal unit (RTU-2), 120-v ac supply, interface manifold, and sample hood (MCO gas sample line and exhaust system). All piping is stainless steel. Flexible hoses (five total) are stainless steel braided over Teflon ${ }^{1}$ or stainless steel braided over stainless steel or corrugated stainless steel. Figure 4-1 shows a schematic illustration of the MCO sample cart. See drawings H-2-120403 and H-2-128000 for additional details.

The 120-psig-helium supply system is connected to the sample cart through a 1-inch diameter flexible hose and quick connects near the sample/weld pits. Sample cart equipment divides the 120-psig-helium supply into four separate delivery lines. Nominal 12-psig helium is used to purge air from the sample cart and hoses and to refill the monitored MCO to designated gas pressure (as needed), 75-psig helium is used to leak rate test the MCO sample line and valve operator connections before sampling the $\mathrm{MCO}$, and 20-psig helium is used to operate the purge gas control valve actuator for dilution of sample cart exhaust gas. The 120-psig-helium supply is used to purge and dilute MCO sample gas as it is released to the exhaust system at the sample hood.

The RTU provides electrical power for operation and readout of the OCRWM pressure (PIT-721) and temperature (TIT-723) instruments on the sample cart. These readings are also transmitted to the DCS through RTU-2.

The $120-v$ ac supply voltage at utility Pits \#3 or \#6 provides electrical power to the process controller for helium purge of the MCO sample gas from the sample cart.

\footnotetext{
${ }^{1}$ Teflon is a trademark of E. I. DuPont de Nemours and Company
} 


\subsubsection{Interface Manifold}

The interface manifold is used to obtain the helium blank sample and MCO gas sample from the sample cart. The interface manifold contains valves, vacuum seal fittings, a flexible line, mechanical vacuum pump, pressure indicator instrument, and single port gas sample canister. Helium blank gas or MCO gas is accumulated in the sample cart at positive pressure and sampled by drawing a vacuum $(<0.1$ torr per OP-23-002S) on the interface manifold (including the flex hose, tubing, and sample canister) and then opening the sample valve (MCO-V-152) on the sample cart for pressurized gas flow into the evacuated interface manifold and sample canister. The gas sample is collected and the valve on the sample canister is closed. The excess gas in the sample cart and interface manifold is vented to the sample hood before disconnecting the closed sample canister.

A 120-v ac supply voltage on the south wall of the CSB operating deck provides electrical power to the vacuum pump and vacuum indicator instrument. Figure 4-1 shows a schematic illustration of the sample interface manifold and support equipment. Figure 4-2 is an expanded illustration of the sample interface manifold. See Drawing H-2-120403, Sheet 3 for additional details.

Pacific Northwest National Laboratory (PNNL) provided the pre-evacuated sample canisters $\left(75 \mathrm{~cm}^{3}\right)$ and analyzed the helium blank and training MCO gas samples. The sample canisters are evacuated to $<0.1$ torr (as indicated in PI-743) on the interface manifold before taking of the sample to ensure no air has leaked into the canister during storage.

\subsubsection{Helium Supply System}

The helium supply system (GBM-5) for the sample/weld stations is an eight bottle double manifold (six bottles shown) with manual valves, pressure indicators and pressure safety relief valves. GBM-5 is located in the south vestibule of the CSB. One gas bottle is used to provide a low-pressure purge of the helium supply piping between MCO gas sampling events. Figure 4-1 is a schematic illustration showing the 4,000-psig helium supply system. See Drawing H-2-125162, Sheet 9 for additional details.

\subsection{Equipment Testing}

In 1999, Startup Test Engineering directed and supervised a preoperational acceptance test (PAT) of the sampling system (Test Results Package SNF-W379-TRP-023). This initial testing demonstrated that the sampling process (including the sample cart, cranes, sample hood, rotational drives, exhaust system and chiller) functioned as designed.

In 2001, CSB Operations performed subsequent validation tests of the equipment at normal operating conditions and in its final in-service configuration under the direction of CSB Engineering. Operations support and Quality Assurance organizations participated in the tests. Approved procedures were used to test and validate the sampling system before monitored MCO gas sampling. 
The validation testing included chain-of-custody delivery of gas samples to PNNL for analysis by a mass spectrograph. Preliminary sample results from helium blank and training MCO samples were available within a few hours after sampling. Final results are included in Appendix B. 
Figure 4-2: Sample Interface for CART-001

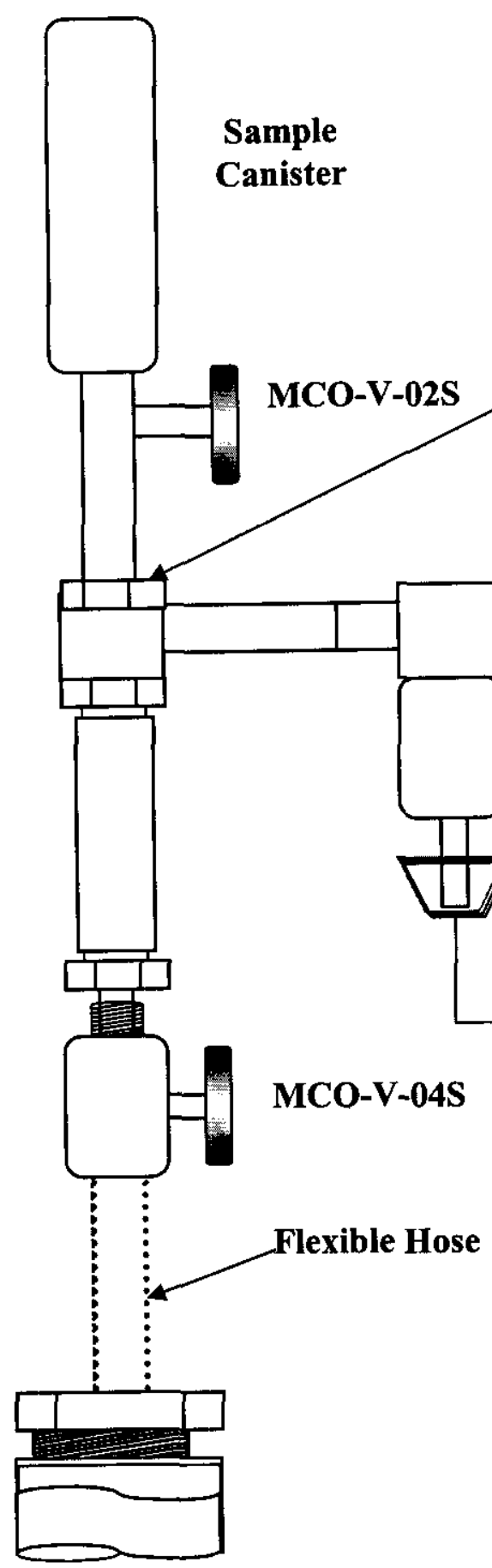

Sample Valve MCO-V-152

On Sample Cart

See Figure 4-1 


\subsection{Procedures}

Procedures that were used to implement validation testing included the work package, operating procedures, maintenance procedures, and analytical procedures.

\subsubsection{Work Package}

Work package 1S-01-00586 Sample/Weld Station Hands On Work was used to perform sample station hands on work, personnel training, procedure verification, and functional test of the equipment used for training MCO gas sampling.

\subsubsection{Operating Procedures}

Operating procedure OP-23-002S Operate MCO Sample Station (OCRWM) was used to operate the MCO sampling equipment. If a limit and/or control were not in compliance or if the procedure could not be performed in compliance with the limit or control, then management was notified immediately and Technical Procedure Change Requests (TPCR) were generated and implemented when appropriate.

The operating procedure was controlled in accordance with requirements identified in OCRWM/Quality Assurance Requirements and Descriptions (QARD) DeKlever (2000). OCRWM and QARD designators are included in the body of the procedure. The procedure contains Traveler Pointer markers to indicate associated steps in the traveler that require information to be documented (CP-70-007) and reference to TSR/process standard limits and controls (PS 610).

\subsubsection{Maintenance Procedures}

Maintenance procedures include surveillance procedures (SP), maintenance procedures (MP), and work packages (WP). Surveillance procedures and MPs were used to calibrate instruments and inspect equipment. Work packages were used to correct discrepancies found during training and validation testing. Table 4-1 is a list of the procedures used for MCO gas sample training and validation testing. 
Table 4-1: Maintenance Procedures and Work Packages for MCO Gas Sample Training and Validation Testing

\begin{tabular}{|c|c|}
\hline $\begin{array}{l}\text { Procedure Work } \\
\text { Package Number }\end{array}$ & 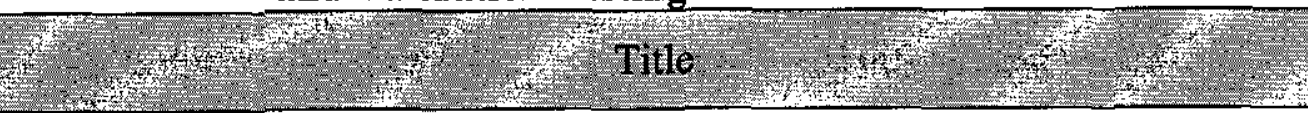 \\
\hline SP-23-001S & $\begin{array}{l}\text { Calibration of Sample/Weld Hood Differential Pressure Indicators PDI-732, } \\
\text { PDI-737, PDI-739 }\end{array}$ \\
\hline SP-23-002S & $\begin{array}{l}\text { Calibration of Sample/Weld Station Flow Indicators FI-740, FI-741, } \\
\text { And Differential Pressure Indicators PDI-734, PDI-735 }\end{array}$ \\
\hline SP-23-003S & Calibration of Sample Cart Pressure Instrument PIT-721 (OCRWM) \\
\hline SP-23-004S & Calibration of Sample Cart Temperature Instrument TIT-723 (OCRWM) \\
\hline SP-23-005S & $\begin{array}{l}\text { Periodic Inspection of Sample/Weld Stations Cranes CRN-009 } \\
\text { And CRN-010 }\end{array}$ \\
\hline SP-23-006S & $\begin{array}{l}\text { Calibration of Sample Station Exhaust Differential Pressure Indicators } \\
\text { PDI-734 and PDI-735 }\end{array}$ \\
\hline MP-23-001S & Inspect-Service MCO Sample Cart \\
\hline MP-23-006S & $\begin{array}{l}\text { Frequent Inspection of Sample/Weld Station Cranes CRN-009 } \\
\text { And CRN-010 }\end{array}$ \\
\hline MP-23-014S & Inspect Sample/Weld Station Exhauster Motor AH-006 \\
\hline $1 \mathrm{~S}-00-00341 / \mathrm{M}$ & Modify/Repair Helium Supply System \\
\hline $1 \mathrm{~S}-01-00586$ & Sample/Weld Station Hands On Work \\
\hline $1 \mathrm{~S}-01-00591$ & Instrument Calibration \\
\hline $1 \mathrm{~S}-01-00601$ & Change PIT-721 Local Display to Read in Psi \\
\hline $1 \mathrm{~S}-01-00655$ & Trouble Shoot and Repair MCO Sample Cart Leaks \\
\hline $1 \mathrm{~S}-01-00656$ & Add Strain Relief to Amphenol at Sample Station \\
\hline $1 \mathrm{~S}-01-00669$ & Function Test Foxboro Controller Sample Cart \\
\hline 1S-01-00682 & Take Flow Measurements From Sample Cart \\
\hline $1 \mathrm{~S}-01-00710$ & Functional Check of TE-731B and TT-731B \\
\hline $1 \mathrm{~S}-01-00711$ & Obtain Sample From Dummy MCO \\
\hline $1 \mathrm{~S}-02-00013$ & Obtain Sample From Dummy MCO in Sample Pit \\
\hline $1 \mathrm{~S}-02-00021$ & CSB Annual Sample Cart Temperature Instrument Calibration \\
\hline $1 \mathrm{~S}-02-00022$ & TE-723 Functional Check Prior to Sample Analysis \\
\hline $1 \mathrm{~S}-02-00447$ & Install TE-723 in Sample Cart \\
\hline
\end{tabular}

\subsubsection{Sample Control and Laboratory Analysis Procedures}

Procedure OP-23-002S and Administrative Procedure EN-6-016-02, Spent Nuclear Fuel Project OCRWM Sample Control (FH 2002d) were used to obtain and control the helium blank samples and the training MCO gas samples. A chain of custody was used for each sample. Analysis of the helium and training MCO gas samples was performed by PNNL using QARD compliant procedures approved by the CSB Project. 
Spent Nuclear Fuel Project Canister Storage Building

SNF-10618

Multi-Canister Overpack Sampling System Validation (OCRWM)

Rev. 0

\subsubsection{MCO Sampling Process}

Two sampling processes were used to obtain gas samples from the training $\mathrm{MCO}$. The conventional MCO sampling process is designed to use the MCO sample cart and interface manifold system for obtaining helium blank and MCO gas samples as described in Procedure OP-23-002S. The conventional process includes refilling of the MCO with helium that meets OCRWM requirements.

The conventional process includes the following steps:

- Install sample hood over training MCO. Start sample hood exhaust system.

- Connect sample cart to sample hood, helium supply, and DCS system.

- Remove training MCO Port \#2 cover plate.

- Purge air from the sample cart piping, flexible hoses, and valve operator. Secure process valve operator to $\mathrm{MCO}$ Port $\# 2$ while purging.

- Perform initial 75-psig-pressure check of sampling piping connection to MCO process port valve.

- Vent gas from pressure test to sample hood to a final pressure $>0$ psig and $<1.0 \mathrm{psig}$.

- Attach sample canister to interface manifold. Evacuate interface manifold and sample canister to less than 0.1 torr as read on PI-743 using mechanical vacuum pump P-5.

- Adjust helium pressure of sample cart to about $12 \mathrm{psig}$, open valves and obtain a blank helium sample in evacuated sample canister.

- Close valves, disconnect sample canister and deliver sample canister to PNNL for analysis. Maintain chain-of-custody for helium blank sample.

- Evaluate laboratory results and ensure blank helium sample meets OCRWM requirements.

- Perform final 75-psig-pressure check of the sampling piping connection to MCO process port valve to verify system leakage is $<40 \mathrm{std} \mathrm{cm}^{3} / \mathrm{sec}$ at $75 \mathrm{psig}$ (LCO 3.2.2).

- Vent gas from pressure test to sample hood to a final pressure $>0 \mathrm{psig}$ and $<1.0 \mathrm{psig}$.

- Attach sample canister to interface manifold. Evacuate interface manifold and sample canister to less than 0.1 torr as read on PI-743 using mechanical vacuum pump P-5.

- Open MCO valve operator and take first pressure reading of MCO on PIT-721.

- Open surge valve to fill MCO cart with MCO gas. Take temperature reading on TIT-723 and second pressure reading of MCO on PIT-721.

- Open sampling valves and obtain an MCO gas sample in evacuated canister. Close sampling valves.

- Compare first pressure reading on PIT-721 and temperature reading on TIT-723 and refill MCO if needed to meet requirements of PS 610 .

- Close MCO process valve operator.

- Vent residual sample cart gas to sample hood exhaust while diluting with controlled 120psig-purge helium supply (PIC-721 and PCV-721).

- Disconnect gas sample canister and deliver to PNNL for analysis. Maintain chain-of-custody for MCO sample.

- Perform leak check of MCO valve operator using PIT-721.

- Shut down and disconnect equipment. Remove sample hood.

- Install MCO Port \#2 cover plate on MCO and leak test to $1 \mathrm{E}-05 \mathrm{std} \mathrm{cm}^{3} / \mathrm{sec}$. 
The direct sampling process does not require helium purging of the sample cart or taking of the helium blank sample. The interface manifold is relocated to the filter test port tee on the inlet line to the sample cart from the training MCO (See Figure 4-1). PIT-721 is disconnected and the fitting plugged. The interface manifold, sample canister and line between the MCO process valve operator and tee are evacuated before opening the MCO process valve operator and taking the training MCO gas sample.

The direct sampling process includes the following steps:

- Relocate interface manifold to the filter test port tee on the sample cart inlet line from the training MCO.

- Disconnect PIT-721 from sample cart and plug fitting.

- Install sample hood over training MCO. Start sample hood exhaust system.

- Connect sample cart to sample hood and helium supply.

- Remove MCO Port \# 2 cover plate and attach valve operator to training MCO.

- Attach sample canister to interface manifold. Evacuate interface manifold, sample canister and hose to MCO process valve operator to less than 0.1 torr as read on PI-743 using mechanical vacuum pump P-5.

- Open MCO process valve, pressurize system, and obtain an MCO gas sample in the canister.

- Close process valve operator and sampling valves.

- Vent sample cart gas to sample hood exhaust while diluting with controlled 120-psig-purge helium supply. Operate PIC-721 on manual mode.

- Disconnect sample canister and deliver sample canister to PNNL for analysis. Maintain chain-of-custody for MCO gas sample.

- Shut down and disconnect equipment. Remove sample hood.

- Install MCO Port \#2 cover plate on training MCO and leak test to $1 \mathrm{E}-05 \mathrm{std}$. cc/sec.

- Return sample cart equipment to standard configuration.

\subsection{OCRWM Certification}

MCOs containing spent nuclear fuel (SNF) stored at the CSB will eventually be transferred to a federal repository for permanent storage. To assure acceptance by the repository, the SNF Project must meet OCRWM/QARD requirements. DeKlever (2000) identified items and activities that require application of OCRWM/QARD requirements ("Q-List").

Items that require certification to meet QARD requirements for $\mathrm{MCO}$ gas sampling are:

- The pressure (PIT-721) and temperature (TE-723/TIT-723) instruments on the sample cart, which measure OCRWM data from the monitored MCOs.

- Helium gas purity $(>99.5 \%)$.

Activities that require documentation to meet OCWRM requirements for MCO gas sampling are:

- Records of helium received, OCWRM certification package(s) of refill helium for OCRWM/QARD application and the sampling and analysis of helium to ensure non- 
approved materials are not admitted to a monitored MCO and are OCRWM lifetime Quality Assurance (QA) records. Calibration records of the pressure and temperature instruments used to provide these data are also considered OCRWM lifetime records.

- Data developed by CSB that are needed by OCRWM as identified in contractual direction from U.S. Department of Energy, Richland Operations Office (none identified at this time).

\subsubsection{MCO Sample Cart Pressure Indicating Transmitter}

Pressure indicating transmitter PIT-721 is a "Q-List" item because it provides gas pressure data required for OCRWM hydrogen gas calculations for the monitored MCOs. It will also measure the pressure of helium added to the sampled MCO to re-establish a baseline pressure before the $\mathrm{MCO}$ is returned to a storage tube.

PIT-721 was purchased as a general service, Quality Level 3-item. It meets the standard for National Fire Protection Association Class 1, Division 2 instruments. Critical characteristics for OCRWM dedication and verification are listed in Table 4-2. Initial calibration was performed under work package 1S-01-00591. Future calibrations will be performed under new work packages on a set frequency determined by CSB Engineering.

Table 4-2: Critical Characteristics and Verification Methods PIT-721

\begin{tabular}{|c|c|c|c|c|c|}
\hline 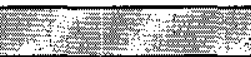 & Critical Characteristi & 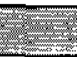 & Wht & $\mathrm{F}=\mathrm{V}$ & ication \\
\hline Characteristic & Acceptance & ID & Function & Method & Procedure \\
\hline Manufacturer & Rosemount & $\mathrm{X}$ & & Inspect & N/A \\
\hline Model No. & 3051CGA22A1AB4E5M5 & $\mathrm{X}$ & & Inspect & N/A \\
\hline $\begin{array}{l}\text { Functional } \\
\text { Pressure } \\
\text { Readout } \\
\end{array}$ & Local display calibrated & & $\mathrm{X}$ & Test & SP-23-003S \\
\hline $\begin{array}{l}\text { Connections } \\
\text { Integrity }\end{array}$ & No faults detected & & $X$ & Test & SP-23-003S \\
\hline Accuracy & $\begin{array}{c}+/-0.5 \% \text { range of } \\
\text { instrument }(+/-8 \mathrm{psig})\end{array}$ & & $\mathrm{X}$ & Test & SP-23-003S \\
\hline $\begin{array}{l}\text { Range of } \\
\text { Instrument }\end{array}$ & 0 to $160 \mathrm{psig}$ & & $\mathrm{X}$ & Test & SP-23-003S \\
\hline
\end{tabular}

\subsubsection{MCO Sample Cart Temperature Element and Transmitter}

Temperature Element TE-723 and the associated Temperature Indicating Transmitter TIT-723 are "Q-List" items because they provide temperature data required for OCRWM hydrogen gas calculation for the monitored MCOs. Temperature of the internal gas is used to calculate the amount of helium and hydrogen in the MCO. 
The instrument was purchased as a general service, Quality Level 3 item. It meets the standard for National Fire Protection Association Class 1, Division 2 instruments. Critical characteristics for OCRWM dedication and verification are listed in Table 4-3. Calibration was performed under work package 1S-02-00021. Functional check of TE-723 was performed under work package 1S-02-00022. Future calibrations will be performed under new work packages on a set frequency determined by CSB Engineering.

Table 4-3: Critical Characteristics and Verification Methods for TE/TIT-723

\begin{tabular}{|c|c|c|c|c|c|}
\hline 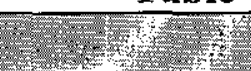 & \multicolumn{3}{|c|}{ Critical Characteristies } & \multicolumn{2}{|c|}{ Venification } \\
\hline Characteristic & Acceptance & ID & Function & Method & Procedure \\
\hline Manufacturer & Watlow \& Rosemount & $\mathrm{X}$ & & Inspect & N/A \\
\hline Model No. & $\begin{array}{l}\text { ARGHFOA030-GT000 or } \\
\text { ARGHFOF030-GT000 } \\
\text { \& 444TT1U1B2K5 }\end{array}$ & $\mathrm{X}$ & & Inspect & N/A \\
\hline $\begin{array}{l}\text { Connections } \\
\text { Integrity }\end{array}$ & $\begin{array}{c}\text { TE-723 to TIT-723 } \\
\text { Connected }\end{array}$ & & $\mathrm{X}$ & Test & SP-23-004S \\
\hline Accuracy & $\begin{array}{c}+/-2 \% \text { range of } \\
\text { instrument }\left(+/-6^{\circ} \mathrm{F}\right)\end{array}$ & & $\mathrm{X}$ & Test & SP-23-004S \\
\hline $\begin{array}{l}\text { Range of } \\
\text { Instrument }\end{array}$ & $0^{\circ} \mathrm{F}$ to $300^{\circ} \mathrm{F}$ & & $X$ & Test & SP-23-004S \\
\hline
\end{tabular}

\subsubsection{Helium Gas Supply}

High purity helium is the only material introduced into the monitored MCOs at the CSB. The monitored MCO helium is a "Q-List" item because it could potentially be added to the MCO and assures that repository requirements are met for protection of the MCO from excessive oxidants and impurities.

Monitored MCO helium is procured as a general service Quality Level 3 item and verified acceptable based on documentation supplied by the vendor and reviewed during receipt inspections and subsequently certified in accordance with Administrative Procedure Certification of $Q$-Listed Items to OCRWM/QARD, (AP-EN-6-038), prior to use in sampling activities. Prior to start of MCO sampling activities, the associated helium supply lines, sample cart and flexible hoses are purged with helium and a confirmatory helium (blank) sample is taken and tested by an approved vendor (PNNL) to ensure desired helium purity levels are maintained. The gas sample analysis is compliant with the vendor OCRWM/QARD requirements approved by the SNF Project.

Critical characteristics for OCRWM dedication and verification of the monitored MCO helium are listed in Table 4-4. 
Table 4-4: Critical Characteristics and Verification of Monitored MCO Helium

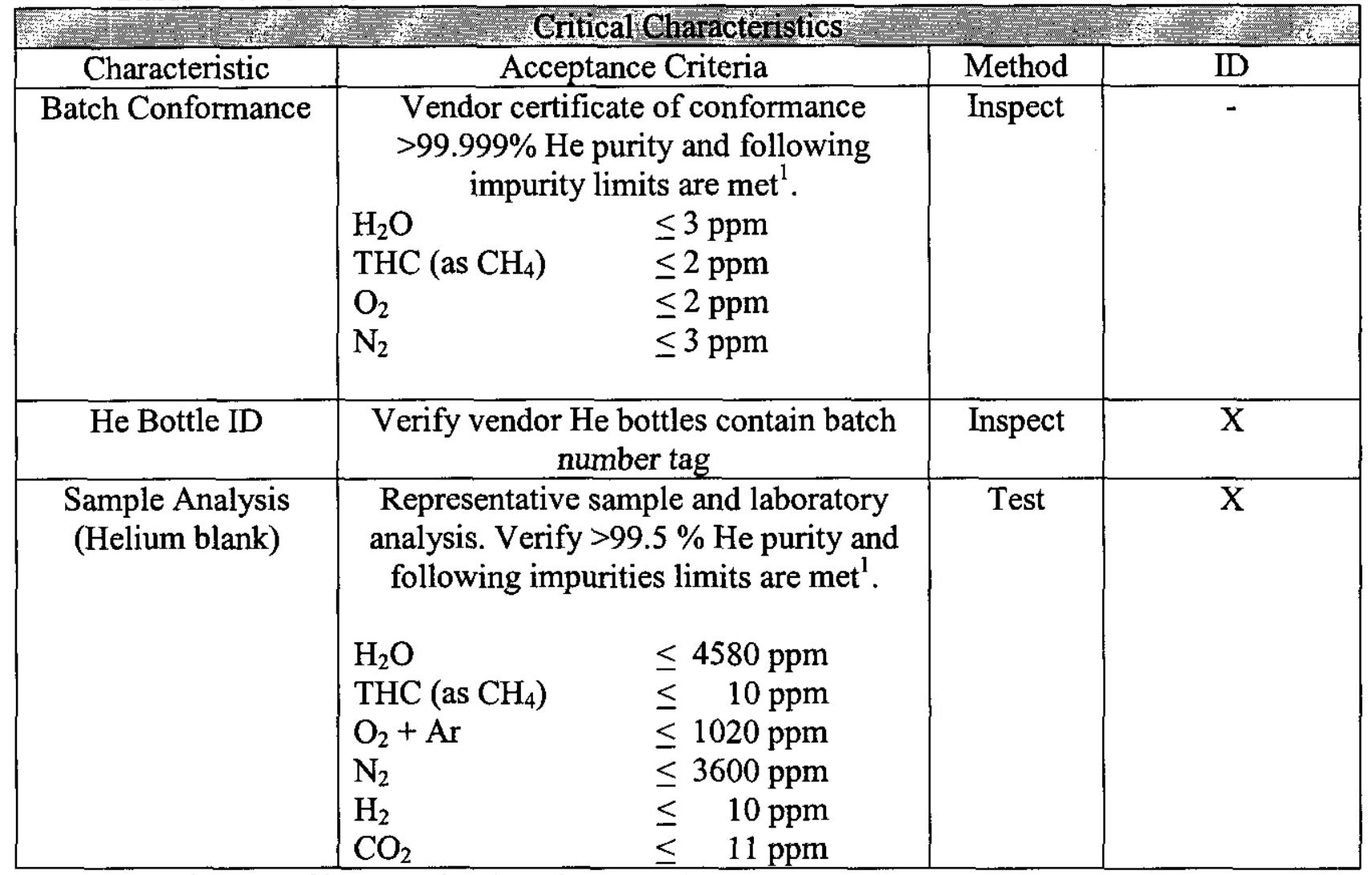

Notes:1) Source of information is Krieg (2002)

\subsubsection{Gas Sample Canisters}

The sample canisters (single valve, nominal $75 \mathrm{~cm}^{3}$ void volume and fabricated of stainless steel) are supplied by PNNL and used for both the helium blank and MCO gas samples. A vacuum seal fitting is used to connect the sample canister to the MCO sample interface manifold. The sample canisters have been factory cleaned initially and evacuated to $1 \mathrm{E}-05$ torr by PNNL before transport to CSB. (Note: The sample interface manifold and sample canister are re-evacuated to less than 0.1 torr using the mechanical vacuum pump before the gas sample is obtained from the sample cart).

\subsection{Analysis of Gas Samples}

The helium blank and MCO gas samples are released from the CSB and transported under chainof-custody to PNNL for receipt and analysis. Trained personnel use a mass spectrograph, support equipment and QARD compliant procedures to analyze the gas samples. The helium blank gas sample and MCO sample gas are analyzed to OCRWM requirements (FH 2002a). 
Pacific Northwest National Laboratory issues a letter with preliminary sample results and then a final report that contains the results of the analyses. These results include a summary data table and narrative describing any anomalies with the data, chain-of-custody forms, evidence of adherence to the OCRWM QA program, results of Quality Control and calibrations required by the analysis procedure, traceability of any laboratory sub-samples to original field samples, and evacuation record of the sample canisters for use at CSB (See Appendix B for details). Table 4-5 lists the constituents and precision requirements (FH 2002e, FH 2002f).

Table 4-5: Gas Sample Analysis and Precision Requirements

\begin{tabular}{|c|c|c|}
\hline Sample & Constituent & Analysis Precision \\
\hline \multirow{11}{*}{ Helium Blank } & $\mathrm{He}$ & \multirow{11}{*}{$\begin{array}{l}+/-2 \% \text { for constituents } \\
\text { with concentrations } \\
>500 \mathrm{ppm} \\
\text { - } \\
\text { Best effort for constituents } \\
\text { with concentrations } \\
\leq 500 \mathrm{ppm}\end{array}$} \\
\hline & $\mathrm{N}_{2}$ & \\
\hline & $\mathrm{H}_{2}$ & \\
\hline & $\mathrm{O}_{2}$ & \\
\hline & $\mathrm{Ar}$ & \\
\hline & $\mathrm{Ne}$ & \\
\hline & $\mathrm{CO}$ & \\
\hline & $\mathrm{CO}_{2}$ & \\
\hline & $\mathrm{NO}_{\mathrm{x}}$ & \\
\hline & Total hydrocarbons as $\mathrm{CH}_{4}$ & \\
\hline & $\mathrm{H}_{2} \mathrm{O}$ & \\
\hline \multirow[t]{12}{*}{$\mathrm{MCO}$} & $\mathrm{He}$ & \multirow{12}{*}{$\begin{array}{l}+/-2 \% \text { for constituents } \\
\text { with concentrations } \\
>500 \mathrm{ppm} \\
\text { Best effort for constituents } \\
\text { with concentrations } \\
\leq 500 \mathrm{ppm}\end{array}$} \\
\hline & $\mathrm{H}_{2}$ & \\
\hline & $\mathrm{O}_{2}$ & \\
\hline & $\mathrm{N}_{2}$ & \\
\hline & $\mathrm{Ar}$ & \\
\hline & $\mathrm{Kr}$ & \\
\hline & $\mathrm{Xe}$ & \\
\hline & $\mathrm{CO}$ & \\
\hline & $\mathrm{CO}_{2}$ & \\
\hline & $\mathrm{NO}_{\mathrm{x}}$ & \\
\hline & Total hydrocarbons as $\mathrm{CH}_{4}$ & \\
\hline & $\mathrm{H}_{2} \mathrm{O}$ & \\
\hline
\end{tabular}




\subsection{EQUIPMENT TESTS}

The 1999 PAT demonstrated that the sampling process (including the sample cart, cranes, sample hood, rotational drives, exhaust system and chiller) works as designed (Test Results Package SNF-W-379-TRP-023). Design changes to the sampling system and helium supply since completion of the PAT necessitated additional testing of the equipment. After modifications to the sampling system were made, validation tests were performed at normal operating conditions and in-service configuration to validate the sampling equipment system for MCO gas sampling. Maintenance procedures complemented the validation testing. This section describes the final equipment tests for the sample cart, gas sampling, and helium refill of the training MCO.

\subsection{MCO Sample Cart}

Equipment modification to the sample cart and interface manifold were completed on December 11, 2001. Validation testing started on December 12, 2001 using WP 1S-01-00586 and OP-23-002S. CSB Operations performed the tests at normal operating conditions and final in-service configuration. Training MCO TR-003 was used for the validation testing.

CSB Operations performed the tests under the direction of CSB Engineering. Operations support and QA organizations were also involved. Maintenance performed leak tests and instrument calibrations under work package control. All testing, maintenance and qualifications were completed on January 16, 2002.

Some procedure changes were required to improve operation and/or clarify instructions. If a limit and/or control were not in compliance or if the procedure could not be performed in compliance with the limit or control, then management was notified immediately and a TPCR was written and incorporated as necessary.

\subsubsection{Validation Tests}

Helium blank samples and training MCO gas samples were obtained during validation testing. Training MCO gas samples were obtained using two sampling methods in order to develop a correlation factor between the helium diluted sample cart samples and undiluted MCO samples (See Section 6.2 for results). The training MCO was refilled with helium to 11.5 psig after the first gas sample because the initial MCO gas pressure (as found) was too low to confidently identify its contents. There was no additional refill of the training MCO during the remaining validation tests.

Helium blank samples were obtained using the sample cart system and instructions in OP-23-002S, which is the MCO standard sampling method (see Figure 4-1). The direct sampling method reconfigured the equipment and used instructions as directed in work packages 1S-01-00711 and 1S-02-0013. Four sets of combined helium blank samples and training MCO gas samples were obtained using OP-23-002S. Two direct MCO gas samples were obtained using reconfigured equipment and instructions in work packages 1S-01-00711 and 1S-02-0013. 
Direct MCO gas sampling used the sample hood, valve operator, front-end portion of the sample cart, and interface manifold. The interface manifold connection was moved from the sample valve (MCO-V-152) to the FH-9 HEPA filter test port tee on the MCO gas supply line of the sample cart. The interface manifold vacuum pump evacuated the supply line and flexible hose back to the MCO process valve operator, interface manifold and sample canister to $<0.1$ torr as read on PI-743. This evacuation activity took about $3 \frac{1}{2}$ hours. The valve operator was opened, pressurizing the sampling system with MCO gas before taking the sample. See Figure 4-1 and Figure 4-2 for information.

\subsubsection{Leak Tests}

The MCO sample cart, sample cart exhaust hose to the sample hood and interface manifold were leak tested before and after validation testing. The systems were pressurized to $30 \mathrm{psig}$ with helium and all fittings and valves were visually checked for leaks $(\sim 1 \times \mathrm{xE}-03 \mathrm{std} \mathrm{cm} / \mathrm{sec})$ using WP 1S-01-00655 and leak detection liquid.

The interface manifold (vacuum seal fittings, valves and pressure indicator) and sample valve MCO-V-152 were gross leak tested by COGEMA Engineering Corporation before validation testing. No leakage was detected after tightening the bolts on the body of sample valve MCO-V-152.

The MCO process valve operator, sample supply hoses, HEPA filter FH-9, fittings and associated valves are pressure leak tested as a unit at 75 psig before opening the MCO process valve operator. Leakage was less than a 1-psi loss after a 10 minute hold period, which meets criteria of less than $40 \mathrm{~cm}^{3} / \mathrm{s}$ (see Appendix A, Section A.4 for details).

\subsubsection{Exhaust Gas Dilution}

The MCO gas in the sample cart is diluted using the 120-psig-supply of helium before it enters the flexible hose to the sample hood exhaust system. The gas pressure of the cart is adjusted for MCO refill (normally about $12 \mathrm{psig}$ ) before it is released to the exhaust system at the sample hood. Proportional controller PIC-721 automatically controls the purge helium. As the gas pressure inside the sample cart (measured by PIT-721) decreases to near atmospheric pressure, the purge helium flow is throttled using valve PCV-721.

A dilution ratio of ten-to-one is used to dilute the sample cart gas. The ten to one dilution assures safe dilution of up to 8 percent hydrogen to less than 25 percent of the lower flammability limit in air based on theoretical amount of hydrogen from sampling a "best estimate" for a single scrap basket MCO after two years of interim storage. This "best estimate" single scrap basket MCO is the baseline $\mathrm{MCO}$ in the CSB process flow diagram by Klem and Pajunen (2000). Duncan (2001) shows that expected hydrogen concentrations for this case are 6.0 percent at zero year and 8.0 percent at two year storage time intervals.

Work packages 1S-01-00669 and 1S-01-00682 were used to establish a correlation between sample cart gas pressures and dilution ratio. A dilution ratio of ten-to-one was achieved by: carefully measuring the bleed flow rate of the cart gas with respect to cart pressure; carefully 
measuring helium purge gas flow rate with respect to throttle valve position; and finally calibration of the proportional controller to provide ten times the helium purge gas with respect to the current cart gas pressure using throttle Valve PCV-721.

\subsection{Helium Supply System}

The helium supply system (GBM-5) for the sample/weld stations is an eight bottle double manifold (six bottles used for MCO gas sampling) with manual valves, pressure indicators and pressure safety relief valves. Work Package 1S-00-00341/M included removal of impurities from the inside of the piping and pressure testing of the system.

\subsection{EQUIPMENT TEST RESULTS}

This section discusses the test criteria, results of the tests and environmental considerations during the testing.

\subsection{Test Criteria and Findings}

The validation test criteria and findings are discussed in the following sections, which include helium purity, integrity of equipment, and operability/reliability of the equipment system.

\subsubsection{Helium Purity}

The helium purity criteria include meeting OCRWM requirements for helium that is used to refill MCOs. Table 4-4 lists the acceptance criteria and control method for ensuring helium purity requirements are met

Inspection and documentation methods are used to control batch conformance and helium bottle identification of purchased helium. During validation testing, no problems were identified with qualification of purchased helium; however the OCRWM document (FH 2002a) must be revised to show batch conformance and bottle identification before new batches of purchased helium maybe used for MCO gas sampling.

Laboratory analysis of sample cart helium is used to qualify MCO refill helium. Table 6-1 compares sample results to the criteria. A few of the blank helium samples did not meet criteria. Loose valves on two sample canisters and/or incomplete helium purging of the sample cart equipment resulted in excess air in helium blank samples $212 \mathrm{H}-121201-1348$ and $212 \mathrm{H}-010402$ 1048. There was excess carbon dioxide in sample $212 \mathrm{H}-010702-2209$.

Instruction was provided in OP-23-002S to improve removal of carbon dioxide and air from the sample equipment by the following actions: a) doubling the purge times to minimum 60 seconds, b) lengthening the time for vacuum pump down of the interface manifold and sample canister to minimum 4 minutes, c) firmly closing the sample canister valve after filling, and d) securing the sample valve closed using tamper-indicating tape. Purity of residual helium in the sample cart is expected to be better than shown in Table 6-1. The second 75 psig pressure test and system venting before opening the $\mathrm{MCO}$ process valve operator are performed after taking the helium 
blank sample. This pressurization and venting purges additional contaminants from the sampling system resulting in improved helium purity.

Table 6-1: Acceptance Criteria and Laboratory Results of Helium Blank Samples ${ }^{1,2}$

\begin{tabular}{|c|c|c|c|c|c|c|c|}
\hline Constituent & Acceptance & $\begin{array}{l}\text { Sample } \\
212 H \\
121201 \\
1348\end{array}$ & $\begin{array}{l}\text { Sample } \\
212 H^{4} \\
121201= \\
2156\end{array}$ & $\begin{array}{c}\text { Sample } \\
2124 \text {. } \\
122001 \\
1336\end{array}$ & $\begin{array}{l}\text { Sample } \\
\begin{array}{l}212 H \\
010402 \\
1048\end{array}\end{array}$ & $\begin{array}{l}\text { Sample } \\
21211 \\
010702 \\
2209\end{array}$ & $\begin{array}{l}\text { Sample } \\
\begin{array}{l}212 \mathrm{H} \\
010902 \\
2144 .\end{array}\end{array}$ \\
\hline $\mathrm{He}$ & $>99.5 \%$ & $99.5 \%$ & $99.99 \%$ & $99.97 \%$ & $99.28 \%$ & $99.98 \%$ & $99.98 \%$ \\
\hline $\mathrm{H}_{2} \mathrm{O}$ & $\leq 4580 \mathrm{ppm}$ & $<1000 \mathrm{ppm}$ & $<1000 \mathrm{ppm}$ & $<100 \mathrm{ppm}$ & $<100 \mathrm{ppm}$ & Not detected & Not detected \\
\hline $\mathrm{THC}\left(\mathrm{CH}_{4}\right)$ & $\leq 10 \mathrm{ppm}$ & $<10$ ppm & $<10$ ppm & $<10$ ppm & $<10 \mathrm{ppm}$ & $<10 \mathrm{ppm}$ & $<10 \mathrm{ppm}$ \\
\hline $\mathrm{O}_{2}+\mathrm{Ar}$ & $\leq 1020 \mathrm{ppm}$ & $970 \mathrm{ppm}$ & $<30 \mathrm{ppm}$ & $<60 \mathrm{ppm}$ & $1390 \mathrm{ppm}$ & $<30 \mathrm{ppm}$ & $<30 \mathrm{ppm}$ \\
\hline $\mathrm{N}_{2}$ & $\leq 3600 \mathrm{ppm}$ & $4130 \mathrm{ppm}$ & $90 \mathrm{ppm}$ & $230 \mathrm{ppm}$ & $5800 \mathrm{ppm}$ & $180 \mathrm{ppm}$ & $170 \mathrm{ppm}$ \\
\hline $\mathrm{H}_{2}$ & $\leq 10 \mathrm{ppm}$ & $<10 \mathrm{ppm}$ & $<10 \mathrm{ppm}$ & $<10 \mathrm{ppm}$ & $<10 \mathrm{ppm}$ & $<10 \mathrm{ppm}$ & $<10 \mathrm{ppm}$ \\
\hline $\mathrm{CO}_{2}$ & $\leq 11 \mathrm{ppm}$ & $<10 \mathrm{ppm}$ & $<10 \mathrm{ppm}$ & $<10 \mathrm{ppm}$ & $10 \mathrm{ppm}$ & $20 \mathrm{ppm}$ & $<10 \mathrm{ppm}$ \\
\hline
\end{tabular}

Notes:

1) Key to sample number system: $212 \mathrm{H}$ is CSB; 121201 is date (month day year) and 1348 is time.

2) Results shown do not include estimate of precision value. See Appendix B for PNNL data transmittal letters.

3) Sample canister valve was reported loose by PNNL. Sample results exceed acceptance criteria.

4) Helium used to refill training MCO to 11.5 psig.

\subsubsection{Sampling System Integrity}

The sampling system integrity criterion includes the MCO process valve operator, sample hood, hoses, sample cart, interface manifold, and helium supply system.

The MCO sample cart, interface manifold, and sample cart exhaust hose to the sample hood were leak tested before and after validation testing. The systems were pressurized to 30 psig with helium and all fittings and valves were visually checked for leaks $(\sim 1 \times \mathrm{xE}-03 \mathrm{std} \mathrm{cm} / \mathrm{sec})$ using Work Package 1S-01-00655 and leak detection liquid. All visible leaks were repaired. The operator for valve PCV-721 utilities continual helium pressure bleed down. The manufacturer reports that the PCV-721 operator has a maximum consumption rate of $0.2 \mathrm{scfm}$ at 20 psig based on air.

The interface manifold (vacuum seal fittings, valves and pressure indicator) and sample valve $\mathrm{MCO}-\mathrm{V}-152$ were gross leak tested by COGEMA Engineering Corporation before validation testing. Leakage was detected initially at the body of sample valve MCO-V-152. After tightening the nuts and bolts on the sample valve body, no helium leakage was detected on the interface manifold.

The MCO process valve operator, sample supply hoses, HEPA Filter FH-9, fittings, and associated valves are pressure leak tested at 75 psig before opening the MCO process valve operator as instructed in OP-23-002S. Typical pressure loss over a 10-minute period was $<1 \mathrm{psi}$

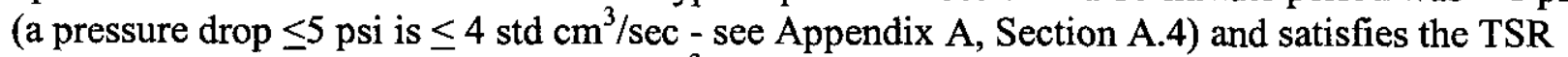
maximum leak rate of less than $40 \mathrm{std} \mathrm{cm}^{3} / \mathrm{sec}$ inside the sample hood. 
The modified helium supply system for MCO gas sampling was internally cleaned of impurities and the entire system (GBM-5 to support utility pits 3 and 6 ) pressure leak tested in accordance with Work Package 1S-00-00341/M. Two leak tests were performed. The first test criterion was less than a 2-psi-pressure loss in 15 minutes at 165 -psig-test pressure. The second test criterion was a helium leakage rate of less than $1 \times E-03 \mathrm{std} . \mathrm{cm}^{3} / \mathrm{sec}$ at 150 -psig using commercial leak detection liquid. Both criteria were met.

\subsection{Training MCO Gas Sample Test Results}

This section discusses the MCO gas sample test results obtained using the conventional and direct sampling methods.

\subsubsection{MCO Sample Cart Results}

Four gas samples were obtained from the training MCO using OP-23-002S. The results are summarized in Table 6-2.

Sample $212 \mathrm{H}-121201-2243$ was the first training $\mathrm{MCO}$ gas sample. The MCO gas pressure was $0.43 \mathrm{psig}$ as measured on the sample supply line to the sample cart (surge valve MCO-V-151 closed) and 0.44 psig when the MCO gas was added to fill the main part of the sample cart (surge valve MCO-V-151 open). Both pressures were measured using PIT-721. The first training gas sample was mostly sample cart helium (sample cart helium pressure reduced to $>0$ psig and $<1.0$ psig before addition of training MCO gas to the main part of the sample cart). The first MCO sample (212H-121201-2243) could not be used to develop the correction factor for the MCO sample cart because of low gas pressure in the "as found" training MCO. The history of training $\mathrm{MCO}$ operations at $\mathrm{K}$ Basins did not provide adequate information about training $\mathrm{MCO}$ gas contents. The training MCO was refilled to 11.5 psig with helium represented by helium blank sample 212H-121201-2156 (see Table 6-1).

PNNL Radio Chemistry Laboratory personnel found a loose valve on the second MCO gas sample canister. The loose valve and/or air contamination of residual helium blank in the sample cart resulted in additional contamination of MCO sample 212H-010402-1143. Since these sample results are very close to the results of third and fourth sample events, air contamination is judged as minor for process calculations. Therefore MCO gas samples 212H-010402-1143, $212 \mathrm{H}-010702-2235$ and $212 \mathrm{H}-010902-2232$ were used to develop the gas correction factors for the MCO sample cart. There were no helium refills of the training MCO after the second sampling event. 
离

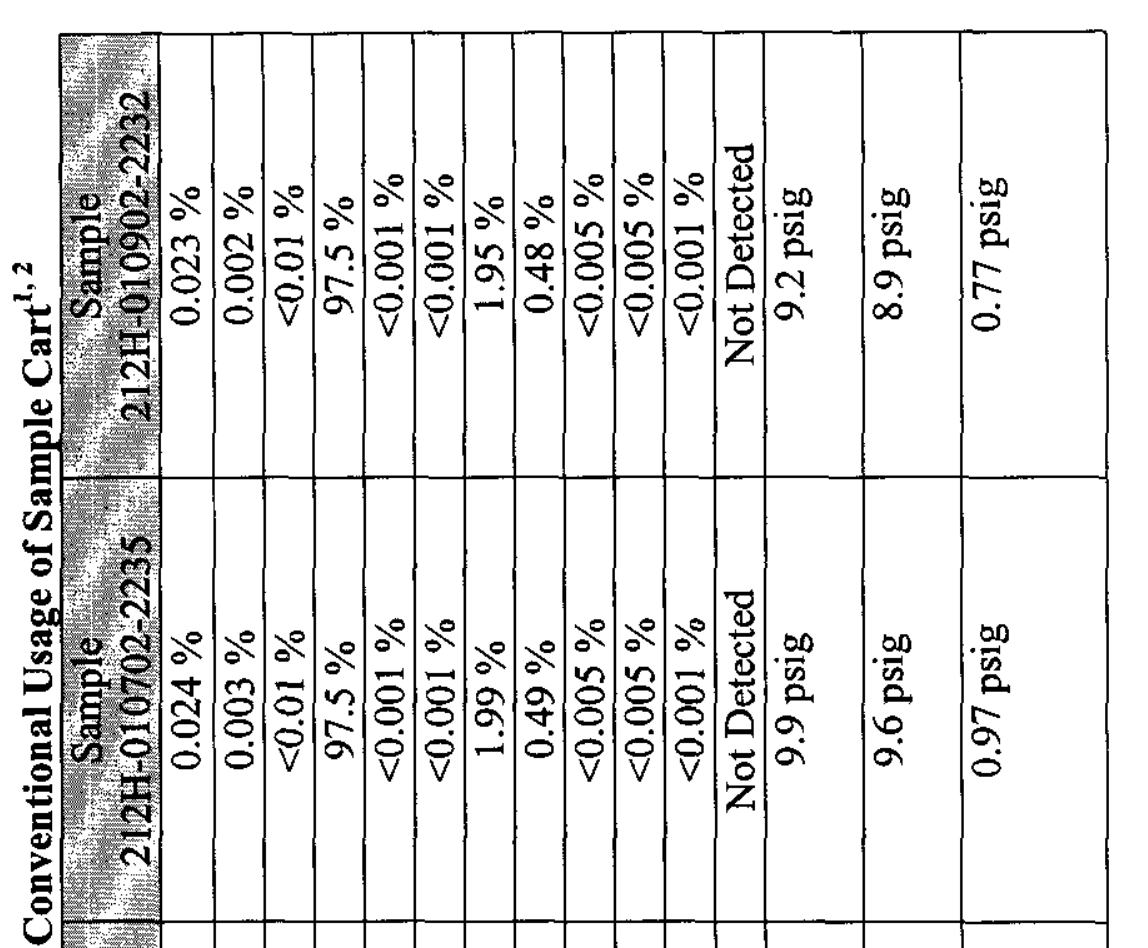

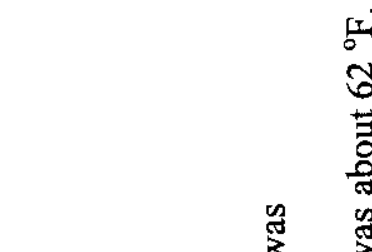

N

*

与

幽

解富

तิ

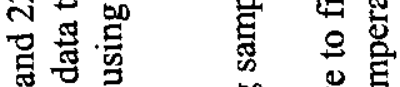

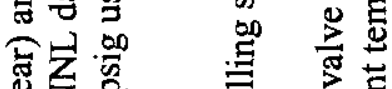
的击 荡

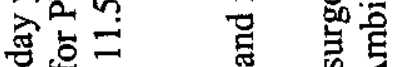
声里

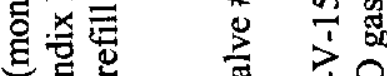

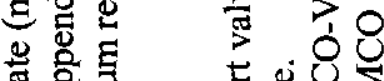
녹 9 远 宁的 군, 긍

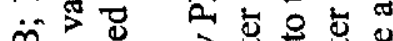
क्षे 品 胥 党

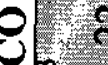

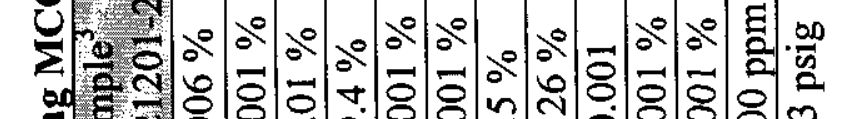
志

光 范 $\frac{1}{0}$ के

它

氖 乙 哥|

若

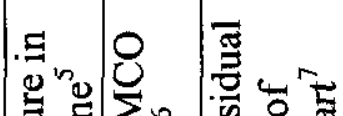

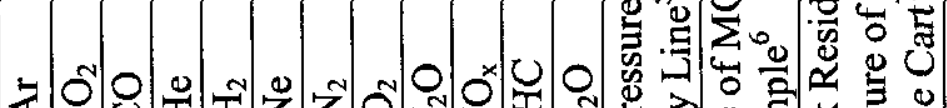

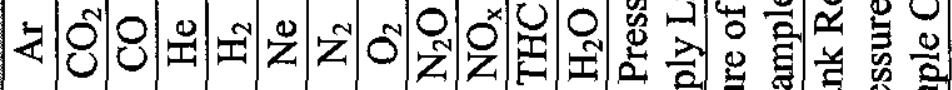

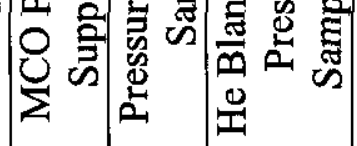

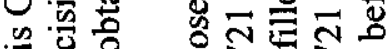

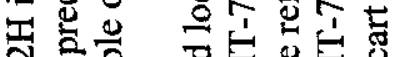
는 뭉

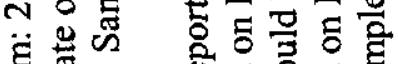

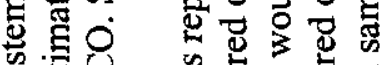

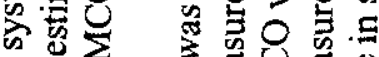
㟧 दิ .

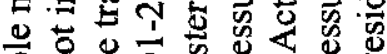

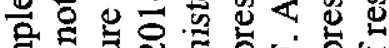
도을 क 00 工

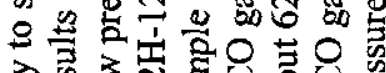

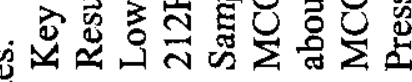
ปลิ สำ 


\subsubsection{MCO Direct Sample Results}

Two direct MCO gas samples were obtained using instructions in WP 1S-01-00711/W and $1 \mathrm{~S}-02-00013 / \mathrm{W}$. The results are nearly identical and are summarized in Table 6-3. The direct sampling equipment configuration moved the interface manifold from the sample cart valve (MCO-V-152) to the HEPA filter (FH-9) test port tee, disconnected tubing to PIT-721 on the sample cart and plugged the pressure tap pipe connection. Measurement of the MCO gas pressure could not be obtained during direct sampling because of equipment configuration. MCO gas pressures are estimated at about 10.1 psig for sample 212H-121901-2332 and about 9.2 psig for sample $212 \mathrm{H}-011002-1517$ based on the ideal gas law. The training MCO was not refilled with helium after the direct sampling events.

Table 6-3: Training MCO Gas Sample Results Based on Direct Samples ${ }^{1,2}$

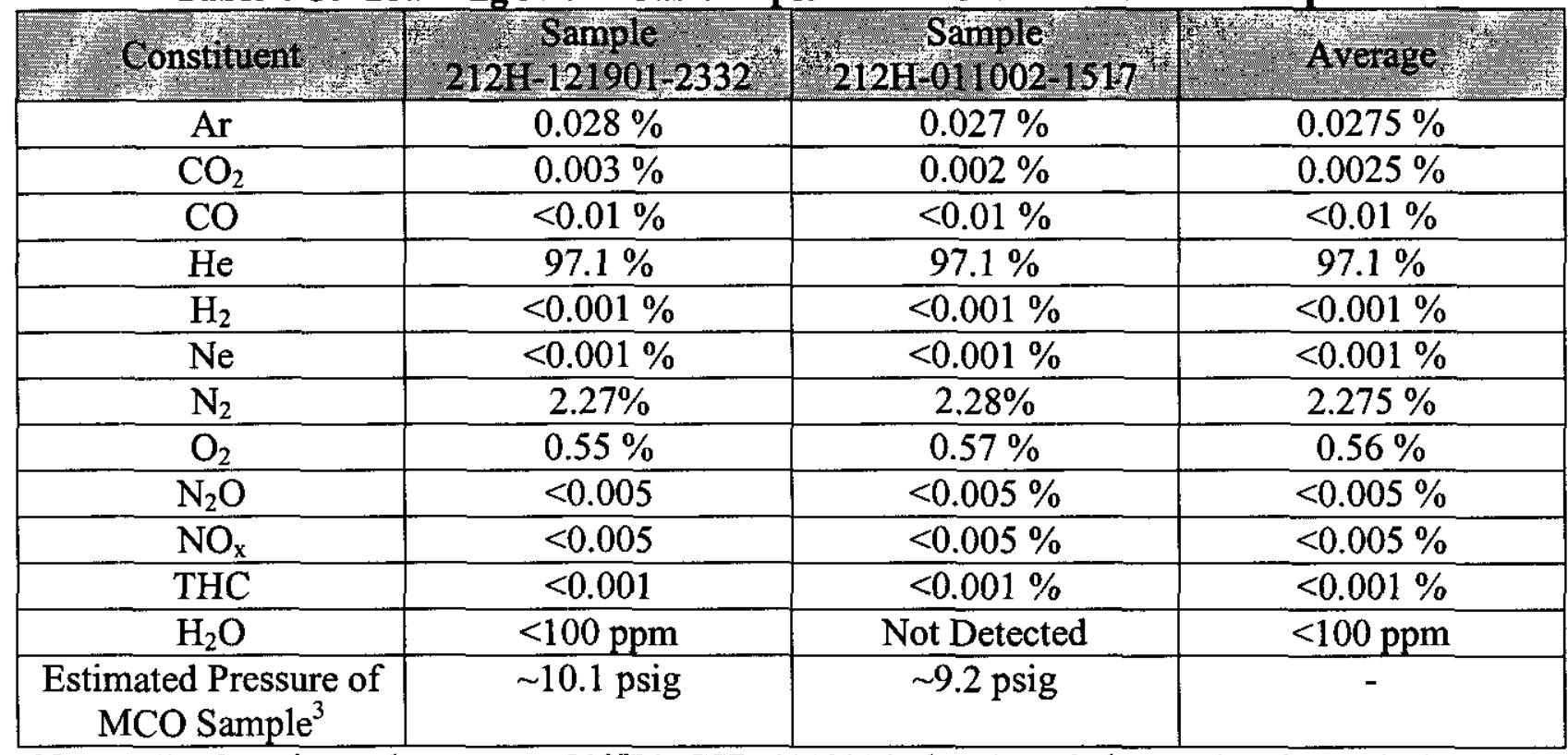

Notes: 1) Sample number system: $212 \mathrm{H}$ is CSB; 121201 is date (month day year) and 1348 is time.

2) Results do not include estimate of precision value. see Appendix B for PNNL data transmittal letters.

3) Actual MCO gas pressure could not be obtained because of equipment configuration. Estimated gas pressure based on ideal gas law.

\subsubsection{Estimated MCO Gas Correlation Factors}

Two correlation factors were developed from test data. The SCF is based on a ratio of constituent concentrations from sample results of the direct $\mathrm{MCO}$ gas sample and the MCO sample cart gas sample. It does not apply corrections for the MCO and sample cart temperature, pressure or void space volume. Equations 8 and 9 summarize this method.

$\mathrm{SCF}=[$ Direct $\mathrm{MCO}$ sample constituent concentration $] /[\mathrm{MCO}$ sample cart sample constituent concentration]

$[\mathrm{MCO}]=[$ Sample Result $] \times \mathrm{SCF}$ 
The average SCFs are about 1.15 for argon, carbon dioxide, nitrogen and oxygen, and 1.00 for helium. See Table 6-4 and Appendix A, Section A.1. The SCFs provide "best estimate" values of the constituent concentrations inside the MCO. Use of correlation factor of 1.14 is recommended to determine the oxygen concentration of the actual MCO.

The TCF is developed from residual helium pressure and final gas pressure conditions in the sample system and represents equilibrium conditions for perfect mixing of all gas in the sample system. Equation 6 and 7 summarize this method.

$\mathrm{TCF}=\mathrm{P}_{\mathrm{f}} /\left(\mathrm{P}_{\mathrm{f}}-\mathrm{P}_{\mathrm{r}}\right)$

$[\mathrm{MCO}]=[$ Sample Result $] \times \mathrm{TCF}$

The average TCF is 2.86 . It is significantly larger than measured during sampling and represents the span of results assuming perfect mixing of all gas in the sample system. See Table 6-4 and Appendix A.1

Table 6-4: Correlation Factors for MCO Gas Sampling

\begin{tabular}{|c|c|c|c|c|}
\hline $\begin{array}{l}\text { He Blank } \\
\text { Sample }\end{array}$ & $2121 \mathrm{log} 0402-1048^{2}$ & $212 \mathrm{H}-0107022209$ & $2124-010902-2144$ & 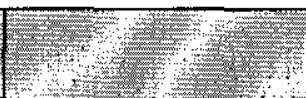 \\
\hline $\begin{array}{c}\text { MCO } \\
\text { Sample Cart } \\
\text { Sample }\end{array}$ & $212 \mathrm{H}-010402-1143^{2}$ & $212 \mathrm{H}-010702-2235$ & $212 \mathrm{H}-0100902-2232$ & $\begin{array}{l}\text { Average } \\
\text { Correlation } \\
\text { Factor }\end{array}$ \\
\hline $\begin{array}{c}\text { Major } \\
\text { Constituent }\end{array}$ & \multicolumn{3}{|c|}{ Sample Based Correlation Factor ${ }^{3}$} & \\
\hline $\mathrm{Ar}$ & 1.15 & 1.15 & 1.20 & 1.17 \\
\hline $\mathrm{CO}_{2}$ & 1.25 & 0.88 & 1.25 & $1.13^{1}$ \\
\hline $\mathrm{He}$ & 0.996 & 0.996 & 0.996 & 1.00 \\
\hline $\mathrm{N}_{2}$ & 1.14 & 1.14 & 1.17 & 1.15 \\
\hline $\mathrm{O}_{2}$ & 1.10 & 1.14 & 1.17 & 1.14 \\
\hline \multirow[t]{2}{*}{ Overall } & 1.13 & 1.06 & 1.16 & 1.12 \\
\hline & \multicolumn{3}{|c|}{ Theoretical (Pressure Based) Correlation Factor ${ }^{4}$} & \\
\hline Overall & $N / A^{5}$ & 2.82 & 2.90 & 2.86 \\
\hline
\end{tabular}

Note: 1) Use value with caution because of difficulty in $\mathrm{CO}_{2}$ removal from equipment.

2) Potential air contamination of this sample because of reported loose sample canister valve by PNNL and/or incomplete purging.

3) Based on Equation 8 (see previous page)

4) Based on Equation 6

5) Not available because residual helium pressure of sample cart was not recorded.

\subsection{System Deficiencies}

This section discusses deficiencies of the MCO sample system that were observed during the validation tests. These deficiencies are specifically related to support equipment, MCO Sample Cart, interface manifold (cart), and operating procedure. 


\subsubsection{Support Equipment}

Pressure regulator PCV-108 of GBM-5 failed to control the helium supply set point pressure at 120 psig. PCV-107 and PCV-108 are parallel pressure regulator valves that are used to control the helium supply pressure to the set point of 120 psig for the sample weld stations. PCV-108 failed to operate properly during validation testing and this required use of PCV-107 to regulate the helium supply pressure. CSB Engineering recommends replacement of PCV-108 with new regulator valve.

Manual valve HE-V-77 of GBM-5 made a loud popping sound when opened. HE-V-77 is an isolation valve on one side of the double manifold 120-psig-helium supply to the sample weld stations. Telephone conversations with the supplier indicate that the valve is questionable and should be replaced; CSB Engineering concurs with the supplier's recommendation.

The low-pressure helium regulator of GBM-5 did not function as designed. The low-pressure system was designed to maintain (via PCV-111) a 3-psig pressure on the piping from GBM-5 to the sample pit isolation valves (HE-V-62-A at Pit 2 and HE-V-63-A at Pit 7) when the system is not in use. CSB Engineering recommends an evaluation and repair of the low-pressure maintenance helium system.

\subsubsection{MCO Sample Cart}

Validation testing has shown that the pressure regulator PCV-726 does not control the sample cart helium at the set point pressure nor does it have the capacity to supply 30-psig-helium for refill of a maximum pressure MCO. PCV-726 provides nominal 12-psig-helium supply for purging of the sample cart, flexible hoses, and refill of the monitored MCOs. Bleed valve HE-V170 is used to maintain the set point pressure of the helium purge. CSB Engineering recommends replacement of PCV-726 with a new regulator with pressure control capacity greater than $30 \mathrm{psig}$. The new regulator should be easily adjustable by the operator and control the pressure to within plus or minus 1 psig of the set point. Bleed valve (HE-V-170) is used to reduce the downstream pressure if the pressure goes above the set point.

Thermocouple (TE-723) was found defective during validation testing and a replacement was ordered. Due to the tight sampling schedule, TE-723 was repaired and re-qualified before the new thermocouple was available. CSB Engineering recommends installation of the replacement thermocouple when convenient. Subsequent calibration information has shown that the repaired thermocouple data collected was valid.

The continuous helium bleed at the operator for valve PCV-721 is a significant source of helium usage. CSB Engineering recommends the installation of a manual valve in the helium supply line to isolate PCV-721 and significantly reduce helium usage.

Temperature indicator (TIT-723) does not have appropriate resolution to accurately observe the sample cart gas temperature. The $20^{\circ} \mathrm{F}$ increments make it difficult to interpolate with good precision the actual MCO gas temperature. CBS Engineering recommends that the current analog temperature indicator be replaced with digital temperature indicator. The digital indicator 
must be OCRWM certified and have appropriate resolution of the temperature over the same range $\left(0^{\circ} \mathrm{F}-300^{\circ} \mathrm{F}\right)$.

\subsubsection{Interface Manifold}

The interface manifold vacuum gauge (PI-743) did not give reliable and repeatable pressure measurement under ambient pressure (non vacuum) conditions. The ambient pressure readings of PI-743 were 1000 torr instead of about 750 torr. CSB Engineering recommends an evaluation of pressure transducer (PT-742) and pressure indicator (PI-743) instruments. Spares for both PT-742 and PI-743 are available for use.

\subsubsection{Operating Procedure}

Improvements to Operating Procedure OP-23-002S will be required because of recommended equipment changes. Further procedure changes could result from proposed follow-on sampling of another training MCO or an MCO with known gas composition. OP-23-002S was developed from drawings of the MCO sampling equipment, vendor equipment information, validation tests results, and initial training of MCO gas sampling at normal operating conditions.

CSB Engineering recommends follow-on evaluation of the sampling operation after completion of proposed equipment changes. The follow-on evaluation is desired in order to better evaluate purging efficiency, potential ingress of air, check correlation factors, improve understanding of mixing behavior of helium and $\mathrm{MCO}$ gas, and provide a basis for additional procedure changes.

\subsection{DISPOSITION OF GAS SAMPLES}

The helium blank and training MCO gas samples are discharged to the PNNL exhaust system and the sample canisters are evacuated to $1 \mathrm{E}-05$ torr after completion of the analysis and approval of the sample report. Empty and evacuated sample canisters $\left(75 \mathrm{~cm}^{3}\right)$ are stored at PNNL or CSB until needed for the next gas-sampling event.

The potential in leakage of air into the PNNL evacuated sample canisters during storage necessitates that the canister be evacuated to $<0.1$ torr using the mechanical vacuum pump on the interface manifold before taking of the sample. The vacuum pump has the capability to achieve a vacuum of 0.01 torr.

\subsection{CONCLUSIONS AND RECOMMENDATIONS}

The validation testing of the MCO sampling system showed that although some minor equipment deficiencies were identified the equipment could be used to satisfactorily sample the first monitored MCO. There is some uncertainty in the results from the training MCO. System improvements are needed to provide flexibility and reduce uncertainty for future MCO gas sampling. 
The following recommendations are provided to improve the gas sampling system.

Support Equipment Improvements:

- Replace failed Pressure Regulator PCV-108 and Manual Valve HE-V-77 of GBM-5.

- Perform evaluation and repair of the low-pressure maintenance system of GBM-5.

MCO Sample Cart Improvements:

- Replace rebuilt Thermocouple TE-723 with the replacement thermocouple.

- Perform calibration checks of repaired and replacement TE-723 thermocouples to meet OCRWM requirements. Calibration verification of the rebuilt thermocouple validates the temperature data obtained during sampling of the actual MCO.

- Replace current analog Temperature Indicator TIT-723 with digital temperature indicator that is OCRWM certified and has more useful readout resolution of the temperature over the same range $\left(0^{\circ} \mathrm{F}-300^{\circ} \mathrm{F}\right)$.

- Replace PCV-726 with a new regulator having higher-pressure control range.

- Install new manual isolation valve on helium supply line to PCV-721 to reduce helium usage.

Interface Manifold Improvements:

- Perform an evaluation of pressure transducer (PT-742) and pressure indicator instruments to determine source of irregular measurements.

Operating Procedure Improvements:

- Revise OP-23-002S to reflect and validate corrected equipment deficiencies.

- Revise OP-23-002S to include the option to perform certain steps in parallel and reduce the time to complete the sampling event.

- Revise OP-23-002S to lengthen the purge time and reduce potential air contamination during future MCO gas sampling.

- Revise OP-23-002S to reduce gas-mixing uncertainty after completion of additional sampling tests.

Additional MCO Sampling Tests:

- Perform additional sampling tests to improve understanding of gas mixing behavior after closing the sample cart surge valve.

Correlation factors were developed to relate results of sample cart samples to results of direct samples of gas inside the training MCO. The average SCF is about 1.15 for argon, carbon dioxide, nitrogen, and oxygen and 1.00 for helium. The oxygen correction factor is 1.14 . These SCFs are "best estimate", their basis is understood, and they can be used without reservation until further notice. TCFs were developed from gas pressure data and represent the span of results for perfect mixing of all gas in the sample system. The average TCF is 2.86 . 
Changes to equipment and to the operating procedure should be implemented to guard against potential air contamination of the sample cart during future MCO gas sampling. Follow-on MCO gas sampling tests are needed to validate the equipment improvements and reduce mixing uncertainty. 


\subsection{REFERENCES}

Bader, K. R., 2002a, Multi-Canister Overpack Monitoring Plan, SNF-5536 Revision 1, Fluor Hanford, Inc., Richland, Washington

Bader, K. R., 2002b, Results of First Sample MCP-036, Fluor Hanford, Inc., Richland, Washington

Black, D. M. and J. A. McClellan, 2001, SNF-8527, Procurement Specification for CSB MCO Sample Hood Upgrade, Fluor Hanford, Inc., Richland, Washington

CP-07-007, Monitored MCO CSB Traveler (OCRWM), Fluor Hanford, Inc., Richland, Washington

DeKlever, R. C., 2000, Application of the Office of Civilian Radioactive waste management Quality Assurance Requirement to the Hanford Spent Nuclear Fuel Project, HNF-SDSNF-RPT-007 Revision 4, Fluor Hanford, Inc., Richland, Washington

Duncan, D. R. 2001, MCO Internal Gas Composition and Pressure During Interim Storage (OCRWM), HNF-SD-SNF-TI-040, Revision 3C, Fluor Hanford, Inc., Richland, Washington

FH 2000, Administrative Procedure EN-6-031-00, Spent Nuclear Fuel Testing Process, Fluor Hanford, Inc., Richland, Washington

FH 2002a, SNF-9416, MCO Helium Cover Gas at the Canister Storage Building OCRWM Certification Form Package, Fluor Hanford, Inc., Richland, Washington

FH 2002b, SNF-9408, MCO Sampling Pressure Indicating Transmitter PIT-721 OCRWM Certification Form, Fluor Hanford, Inc., Richland, Washington

FH 2002c, SNF-9419, MCO Sampling Temperature Element/Transmitter TE-723/TIT-723 OCRWM Certification Form Package, Fluor Hanford, Inc., Richland, Washington

FH 2002d, Administrative Procedure EN-6-016-02, Spent Nuclear Fuel Project OCRWM Sample Control, Fluor Hanford, Inc., Richland, Washington

FH 2002e, Statement of Work for PNNL Support of CSB Sampling Activities for FY 2002 (PNNL Contract Number 8726-3 Revision 2), Fluor Hanford, Inc., Richland, Washington

FH 2002f, Statement of Work for PNNL Support of CSB Sampling Activities for FY 2003 (PNNL Requisition Number 94002), Fluor Hanford, Inc., Richland, Washington

Klem*, M. J. and A. L. Pajunen, 2000, Spent Nuclear Project Canister Storage Building Process Flow Diagram Mass Balance Calculation, SNF-5741, Fluor Hanford, Inc., Richland, Washington *COGEMA Engineering Corporation, Richland, Washington 
Krahn, D. E., 2000, HNF-3672 Rev. 0A, Canister Storage Building Technical Safety Requirement, Fluor Hanford, Inc., Richland, Washington

Krieg, S. A., 2002, SNF-9416 Revision 3, MCO Helium Cover Gas at the Canister Storage Building OCRWM Certification Form Package, Fluor Hanford, Inc., Richland, Washington

OP-23-002S, Operate MCO Sample Station (OCRWM), Fluor Hanford, Inc., Richland, Washington

PS 610, Spent Nuclear Fuel Project Process Standard CSB Sample Hood Exhaust System/Sampling Piping Confinement System, Revision 0, Fluor Hanford, Inc., Richland, Washington

SP-23-003S, Calibration of Sample Cart Pressure Instrument PIT-721 (OCRWM), Revision 0A, Fluor Hanford, Inc., Richland, Washington

SP-23-004S, Calibration of Sample Cart Temperature Instrument TIT-721 (OCRWM), Revision 0E, Fluor Hanford, Inc., Richland, Washington

Test Results Package SNF-W-379-TRP-023 Canister Storage Building (CSB) MCO Sample/Weld Station, Fluor Hanford, Inc., Richland, Washington

Work Package 1S-01-00591, CSB Annual Sample Cart Pressure Transmitter Calibration, Fluor Hanford, Inc., Richland, Washington

Work Package 1S-02-00021, CSB Annual Sample Cart Temperature Instrument Calibration, Fluor Hanford, Inc., Richland, Washington

Work Package 1S-01-00711, Obtain Sample From Dummy MCO, Fluor Hanford, Inc., Richland, Washington

Work Package 1S-02-00013, Obtain Sample From Dummy MCO In Sample Pit, Fluor Hanford, Inc., Richland, Washington

Work Package 1S-02-00447, Install TE-723 in Sample Cart, Fluor Hanford, Inc, Richland, Washington 


\section{APPENDIX A}

SUMMARY OF SAMPLING PROCESS CALCULATIONS 


\section{A.1 Calculate Gas Sample Correlation Factors for Training MCO}

Two correlation factors were developed from test data of training MCO TR-003. The sample based correlation factor (SCF) is the ratio of major constituent concentrations from the direct MCO gas sample and the conventional MCO sample cart gas sample. The MCO gas sample was taken a few minutes after the MCO gas was admitted to the sample cart and mixed with some residual helium in the sample cart system. Concentration ratios do not require corrections for temperature and pressure. The gas temperature in the training $\mathrm{MCO}$ and sample cart was assumed to be the same as the CSB operating deck temperature $\left(62^{\circ} \mathrm{F}\right.$ or $\left.16.7^{\circ} \mathrm{C}\right)$ because TIT-723 was not operational. Equations A-1 and A-2 summarize this method.

$\mathrm{SCF}=$ Direct $\mathrm{MCO}$ sample constituent concentration / MCO sample cart constituent concentration

$$
[\mathrm{MCO}]=[\text { Sample Result }] \times \mathrm{SCF}
$$

The theoretical pressure based correlation factor (TCF) is the ratio of the final gas pressure in the sample system after addition of MCO gas and the final gas pressure corrected for residual helium pressure of the sample cart system before addition of MCO gas. The TCF represents the equilibrium conditions for perfect mixing of all gas in the sample system and upper bound of the correlation factor. There was no correction of pressure due to temperature because the gas in the sample system was at the same temperature. Pressure corrections would be dependent on any temperature change after completion of gas mixing. Equations A-2 and A-3 summarize this method.

$\mathrm{TCF}=\mathrm{P}_{\mathrm{f}} /\left(\mathrm{P}_{\mathrm{f}}-\mathrm{P}_{\mathrm{r}}\right)$

Where: $P_{f}=$ pressure at time of sampling, psia

$P_{r}=$ pressure of residual helium in system before sampling, psia

$$
[\mathrm{MCO}]=[\text { Sample Result }] \times \text { TCF }
$$

Figure A-1 is a schematic showing MCO and MCO sample cart system void volumes. The MCO is attached to the sample cart using a process valve operator and flexible hoses. The process valve operator isolates the MCO from the sampling system. Surge valve MCO-V-151 isolates the MCO gas from the main portion of the sample cart and remains closed to allow for the best measurement of the MCO gas pressure on PIT-721. Opening surge valve MCO-V-151 fills the sample cart (including gas accumulator or reservoir) with MCO gas, permits measurement of the MCO gas temperature on TIT-723 and gas sampling at valve MCO-V-152 using the interface manifold. Valve MCO-V-154 is used to exhaust the sample cart gas to the sample hood exhaust system via a flexible hose. The sample hood and sample cart contain additional equipment that will not be discussed in this section. 


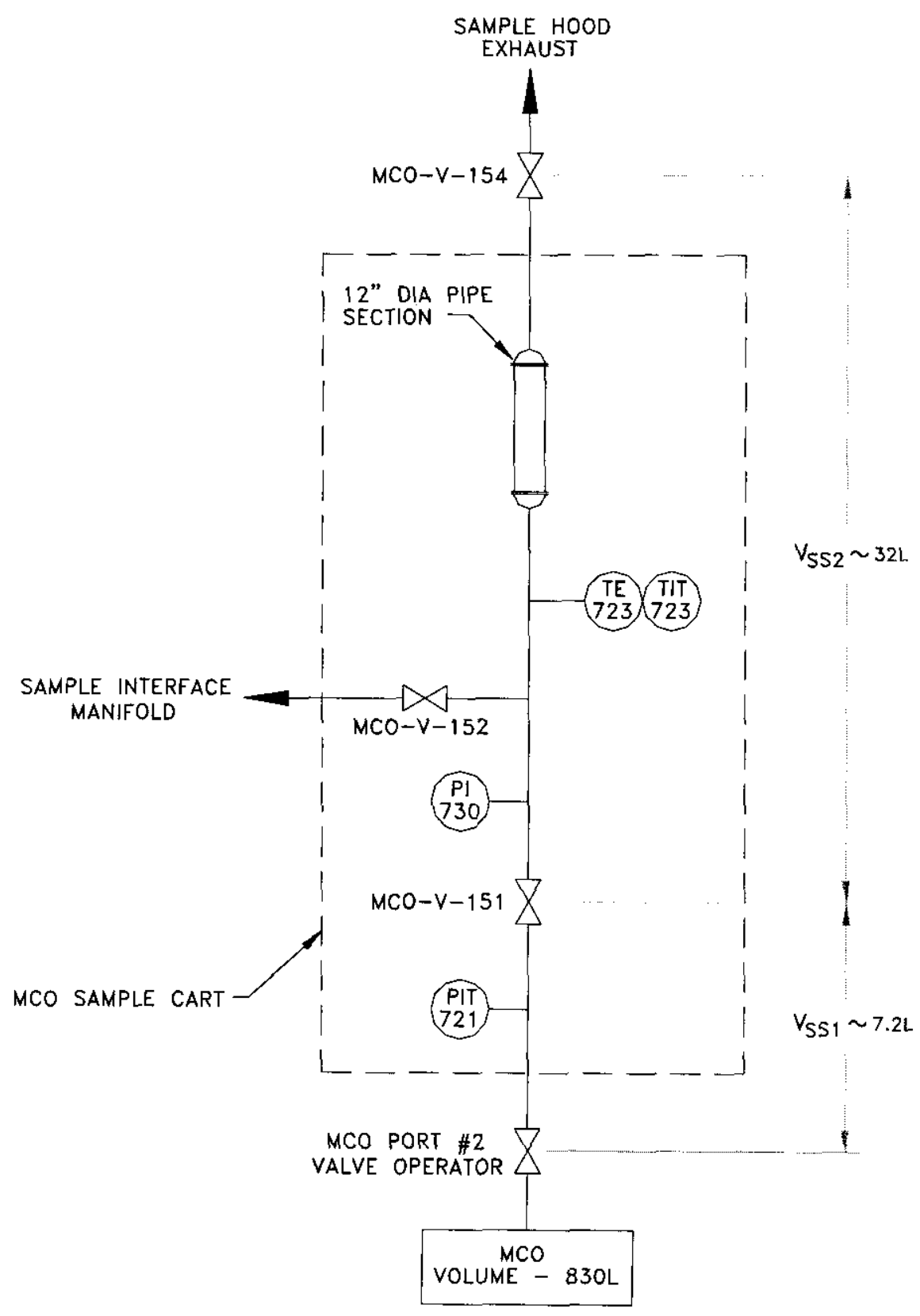


Table A-1 summarizes the helium blank sample results from the conventional sample system. Purity of residual helium is expected to be better than shown below because second 75-psigpressure test and venting operation is performed before opening the MCO valve operator and after taking the helium blank sample. Table A-2 summarizes the valve positions and void volume of residual helium blank in the sample system

Table A-1: Sample Results Helium Blank Major Constituents Based on Conventional Sampling Method

\begin{tabular}{|c|c|c|c|c|c|c|}
\hline $\begin{array}{l}\text { He Blank } \\
\text { Cart Sample }\end{array}$ & $\begin{array}{l}\text { Ar } \\
\text { Mole \% }\end{array}$ & $\begin{array}{l}\mathrm{CO}_{2} \\
\mathrm{Mole} \%\end{array}$ & Mole \% & Mole $\%$ & $\begin{array}{l}\mathrm{O}_{2} \\
\mathrm{Mole} \%\end{array}$ & $\begin{array}{l}\text { Residual } \\
\text { Pressure Psig }\end{array}$ \\
\hline $212 \mathrm{H}-010402-1048$ & $7 \mathrm{E}-03$ & $1 \mathrm{E}-03$ & $9.928 \mathrm{E} 01$ & $5.8 \mathrm{E}-01$ & $1.32 \mathrm{E}-01$ & N/A \\
\hline $212 \mathrm{H}-010702-2209$ & $<1 \bar{E}-03$ & $2 \mathrm{E}-03$ & $9.998 \mathrm{E} 01$ & $1.8 \mathrm{E}-02$ & $2 \mathrm{E}-03$ & 0.97 \\
\hline $212 \mathrm{H}-010902-2144$ & $<1 \mathrm{E}-03$ & $1 \mathrm{E}-03$ & $9.998 \mathrm{E} 01$ & $1.7 \mathrm{E}-02$ & $2 \mathrm{E}-03$ & 0.77 \\
\hline
\end{tabular}

Table A-2: Residual Helium Blank Only Valve Positions

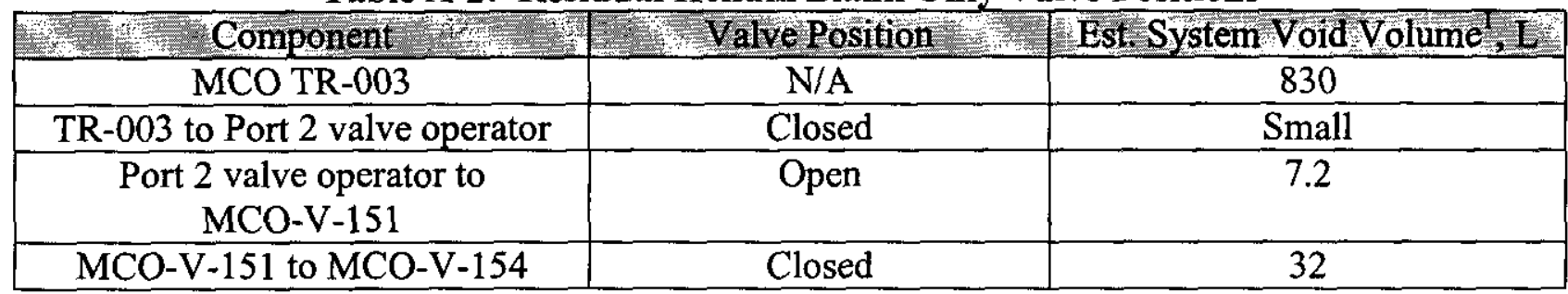

Note: 1) Estimated volume based on physical dimensions of components.

Table A-3 summarizes initial valve positions of the sample system before gas sampling of the training MCO. Table A-4 summarizes the combined residual blank helium and training MCO gas pressures at the head end of the sample cart with valve MCO-V-151 closed. Table A-5 and Table A-6 summarize final valve positions and conditions of the residual blank helium and training MCO gas in the sample system with valve MCO-V-151 open.

Table A-7 lists the sample results of training MCO gas major constituents based on conventional sampling. Table A-8 lists the composition of the training MCO gas major constituents based on direct sampling. Table A-9 summarizes correlation factors as calculated by Equations A-1 and A-3.

Table A-3: Initial Valve Positions for Training MCO Gas

\begin{tabular}{|c|c|c|}
\hline Component & Valve Position & Est System Void Volume, \\
\hline MCO TR-003 & N/A & 830 \\
\hline TR-003 to Port 2valve operator & Open & Small \\
\hline $\begin{array}{c}\text { Port 2 valve operator to } \\
\text { MCO-V-151 }\end{array}$ & Closed & 7.2 \\
\hline MCO-V-151 to MCO-V-154 & Closed & 32 \\
\hline
\end{tabular}

Note: 1) Estimated volume based on physical dimensions of components. 
Table A-4: Training MCO Gas In Head End of Sample Cart with Valve MCO-V-151 Closed

\begin{tabular}{|c|c|c|}
\hline MCO Cart Sample & PTI-721. psig & TIT-723 $\mathrm{F}^{2}$ \\
\hline $212 \mathrm{H}-010402-1143$ & 10.15 & N/A \\
\hline $212 \mathrm{H}-010702-2235$ & 9.94 & N/A \\
\hline $212 \mathrm{H}-010902-2232$ & 9.2 & N/A \\
\hline
\end{tabular}

Table A-5: Final Valve Positions for Training MCO Gas

\begin{tabular}{|c|c|}
\hline Component & Valve Position \\
\hline MCO TR-003 & N/A \\
\hline TR-003 to Port 2 valve operator & Open \\
\hline Port 2 valve operator to MCO-V-151 & Open \\
\hline MCO-V-151 to MCO-V-154 & Closed \\
\hline
\end{tabular}

Table A-6: Training MCO Gas In Sample Cart with MCO-V-151 Open

\begin{tabular}{|c|c|c|}
\hline MCO Cart Sample & TIT-723 \\
\hline $212 \mathrm{H}-010402-1143$ & 9.81 & N/A \\
\hline $212 \mathrm{H}-010702-2235$ & 9.60 & N/A \\
\hline $212 \mathrm{H}-010902-2232$ & 8.93 & N/A \\
\hline
\end{tabular}

Table A-7: Training MCO Gas Major Constituents Based on Conventional Sampling Method

\begin{tabular}{|c|c|c|c|c|c|}
\hline $\begin{array}{r}\text { Training MCO } \\
\text { Conventional }\end{array}$ & $\mathrm{Ar}$ & $\mathrm{CO}_{2}$ & $\mathrm{He}$ & $\mathrm{N}_{2}$ & $\mathrm{O}_{2}$ \\
\hline Sample & & $\mathrm{Mole} \%$ & $\mathrm{Mole} \%$ & $\mathrm{Mole} \%$ & $\mathrm{Mole} \%$ \\
\hline $212 \mathrm{H}-010402-1143$ & $2.4 \mathrm{E}-02$ & $2 \mathrm{E}-03$ & $9.75 \mathrm{E} 01$ & $2.0 \mathrm{E} 00$ & $5.1 \mathrm{E}-01$ \\
\hline $212 \mathrm{H}-010702-2235$ & $2.4 \mathrm{E}-02$ & $3 \mathrm{E}-03$ & $9.75 \mathrm{E} 01$ & $1.99 \mathrm{E} 00$ & $4.9 \mathrm{E}-01$ \\
\hline $212 \mathrm{H}-010902-2232$ & $2.3 \mathrm{E}-02$ & $2 \mathrm{E}-03$ & $9.75 \mathrm{E} 01$ & $1.95 \mathrm{E} 00$ & $4.8 \mathrm{E}-01$ \\
\hline Average & $2.37 \mathrm{E}-02$ & $2.3 \mathrm{E}-03$ & $9.75 \mathrm{E} 01$ & $1.98 \mathrm{E} 00$ & $4.93 \mathrm{E}-01$ \\
\hline
\end{tabular}

Table A-8: Training MCO Gas Composition Based on Direct Sampling Method

\begin{tabular}{|c|c|c|c|c|c|}
\hline Training MCO & \multicolumn{1}{c}{} & $\mathrm{Ar}$ & $\mathrm{CO}$ & $\mathrm{N}$ & $\mathrm{O}_{2}$ \\
\hline Direct Sample & $\mathrm{Mole} \%$ & $\mathrm{Mole} \%$ & $\mathrm{Mole} \%$ & $\mathrm{Mole} \%$ & $\mathrm{Mole} \%$ \\
\hline $212 \mathrm{H}-121901-2332$ & $2.8 \mathrm{E}-02$ & $3 \mathrm{E}-03$ & $9.71 \mathrm{E} 01$ & $2.27 \mathrm{E} 00$ & $5.5 \mathrm{E}-01$ \\
\hline $212 \mathrm{H}-011002-1517$ & $2.7 \mathrm{E}-02$ & $2 \mathrm{E}-03$ & $9.71 \mathrm{E} 01$ & $2.28 \mathrm{E} 00$ & $5.7 \mathrm{E}-01$ \\
\hline Average & $2.75 \mathrm{E}-02$ & $2.5 \mathrm{E}-03$ & $9.71 \mathrm{E} 01$ & $2.275 \mathrm{E} 00$ & $5.6 \mathrm{E}-01$ \\
\hline
\end{tabular}

Table A-9: Major Constituent Correlation Factors

\begin{tabular}{|c|c|c|c|c|c|c|c|c|c|c|}
\hline \multirow{2}{*}{$\begin{array}{l}\text { MCO Cart Sample } \\
\text { M }\end{array}$} & \multicolumn{2}{|c|}{ 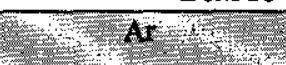 } & \multicolumn{2}{|c|}{$\mathrm{CO}_{2}=$ r } & \multicolumn{2}{|c|}{ 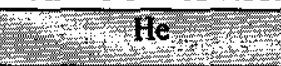 } & \multicolumn{2}{|c|}{$\mathrm{N}^{5}, \mathrm{~N}_{2}$} & \multicolumn{2}{|c|}{$\theta_{2}=\theta_{2}$} \\
\hline & SCF & TCF & $\mathrm{SCF}$ & TCF & $\overline{\text { SCF }}$ & TCF & $\mathrm{CSF}$ & TCF & $\mathrm{SCF}$ & TCF \\
\hline $212 \mathrm{H}-010402-1143$ & 1.15 & N/A & 1.25 & N/A & $0 . \overline{996}$ & N/A & 1.14 & $\mathbf{N} / \mathbf{A}$ & 1.10 & $\widehat{\text { N/A }}$ \\
\hline $212 \mathrm{H}-010702-2235$ & 1.15 & 2.82 & 0.83 & 2.82 & 0.996 & 2.82 & 1.14 & 2.82 & 1.14 & 2.82 \\
\hline $212 \mathrm{H}-010902-2232$ & 1.20 & 2.90 & 1.25 & 2.90 & 0.996 & 2.90 & 1.17 & 2.90 & 1.17 & 2.90 \\
\hline Average & 1.17 & 2.86 & 1.13 & 2.86 & 1.00 & 2.86 & 1.15 & 2.86 & 1.14 & 2.86 \\
\hline
\end{tabular}


Example calculations of the SCF and TCF are shown below for MCO cart sample 212-0107-02-2235.

MCO direct sample average result for $\mathrm{Ar}=2.75 \mathrm{E}-02$ mole $\%$ (See Table A-8)

MCO sample cart result for $\mathrm{Ar}=2.4 \mathrm{E}-02$ mole $\%$ (See Table A-7)

Residual blank He pressure before addition of MCO gas $=P_{r}=0.97$ psig (See Table A-1)

Residual blank He pressure and training gas pressure $\mathrm{MCO}=\mathrm{P}_{\mathrm{f}}=9.60$ psig (See Table A-6)

$\mathrm{SCF} \mathrm{Ar}=[$ Direct $\mathrm{MCO}$ sample $] /[$ Cart MCO sample $]=2.75 \mathrm{E}-02 \% / 2.4 \mathrm{E}-02 \%=1.15$

TCF overall $=\mathrm{P}_{\mathrm{f}} /\left(\mathrm{P}_{\mathrm{f}}-\mathrm{P}_{\mathrm{r}}\right)=(9.60+14.7 \mathrm{psia}) /((9.60-0.97) \mathrm{psi})=2.82$

\section{A.2 Calculate Training MCO Void Volume}

The Ideal Gas Law is used to check the estimated void volume of the training MCO. Equation A-7 relates the observed initial pressures and volumes of the combined training MCO and sample system lines (between process valve operator, surge valve MCO-V-151 and block valve $\mathrm{MCO}-\mathrm{V}-154)$ to the observed final pressure and volumes at the same temperature. The temperature of the equipment was assumed to be the same as the CSB deck temperature $\left(62^{\circ} \mathrm{F}\right.$ or $16.7^{\circ} \mathrm{C}$ ). See Figure A-1.

$\mathrm{P}_{\mathrm{MCO} 1} \times\left(\mathrm{V}_{\mathrm{MCO}}+\mathrm{V}_{\mathrm{SS} 1}\right)+\mathrm{P}_{\mathrm{SS}} \times \mathrm{V}_{\mathrm{SS} 2}=\mathrm{P}_{\mathrm{MCO} 2} \times\left(\mathrm{V}_{\mathrm{MCO}}+\mathrm{V}_{\mathrm{SS} 2}+\mathrm{V}_{\mathrm{SS} 1}\right)$

Substituting and solving Equation A-7 for $\mathrm{V}_{\mathrm{MCO}}$ gives equation A-8.

$\mathrm{V}_{\mathrm{MCO}}=\left[39.2 \mathrm{~L} \times \mathrm{P}_{\mathrm{MCO} 2} \mathrm{psia}-32 \mathrm{~L} \times \mathrm{P}_{\mathrm{Ss}} \mathrm{psia}-7.2 \mathrm{~L} \times \mathrm{P}_{\mathrm{MCO} 1} \mathrm{psia}\right] /\left[\left(\mathrm{P}_{\mathrm{MCO} 1}-\mathrm{P}_{\mathrm{MCO} 2}\right) \mathrm{psi}\right]$

Where:

$\mathrm{P}_{\mathrm{MCO} 1}$ is gas pressure of training MCO as measured on PIT-721 with process valve operator open and MCO-V-151 closed psia.

$\mathrm{P}_{\mathrm{MCO} 2}$ is gas pressure of training $\mathrm{MCO}$ as measured on PIT-721 with process valve operator open, MCO-V-151 open and MCO-V-154 closed psia.

$\mathrm{V}_{\mathrm{MCO}}$ is the training $\mathrm{MCO}$ void volume, $\mathrm{L}$.

$\mathrm{V}_{\text {SS } 1}$ is void volume between Port 2 valve operator and $\mathrm{MCO}-\mathrm{V}-151 \cong 7.2 \mathrm{~L}$.

$\mathrm{V}_{\mathrm{SS} 2}$ is void volume between $\mathrm{MCO}-\mathrm{V}-151$ and $\mathrm{MCO}-\mathrm{V}-154 \cong 32 \mathrm{~L}$.

$\mathrm{P}_{\mathrm{Ss}}$ is gas pressure of residual helium blank in sample system before addition of training MCO gas as measured on PIT-721, psia.

Equation A-9 shows an example calculation based on Equation A-8. Table A-10 lists the gas pressures and calculated void volume of the training MCO. The validation test derived results are within 20 percent of the $830 \mathrm{~L}$ void volume that was estimated from physical dimensions and knowledge of the empty baskets inside the training MCO based on information in Bader (2002b). 
$\mathrm{V}_{\mathrm{MCO}}=[39.2 \mathrm{~L} \times(9.60+14.7 \mathrm{psia})-32 \mathrm{~L} \times(0.97+14.7 \mathrm{psia})-7.2 \mathrm{~L} \times(9.94+14.7$

psia) $] /[9.94-9.60 \mathrm{psi}]=805 \mathrm{~L}$

Table A-10: Void Volume of Training MCO Based on Ideal Gas Law

\begin{tabular}{|c|c|c|c|c|c|c|}
\hline \multirow{2}{*}{ MeO Cart Sample } & \multicolumn{3}{|c|}{ MCO Pressure, psig } & \multirow{2}{*}{$\begin{array}{l}\text { Sample System Residual } \\
\text { Helium Pressure, psig } \\
\text { PSS }_{\text {HS }}\end{array}$} & \multicolumn{2}{|c|}{ MeOVoid Vol, 1} \\
\hline & $\mathrm{P}_{\mathrm{MCO} 1}$ & $\mathrm{P}_{\mathrm{MCO} 2}$ & $\Delta \mathrm{P}_{\mathrm{MCO}}$ & & $\begin{array}{l}\text { Gas } \\
\text { Law }\end{array}$ & $\begin{array}{c}\text { Physical } \\
\text { Dimensions }\end{array}$ \\
\hline $212 \mathrm{H}-010402-1143$ & 10.15 & 9.81 & 0.34 & N/A & $\mathrm{N} / \mathrm{A}$ & 830 \\
\hline $212 \mathrm{H}-010702-2235$ & 9.94 & 9.60 & 0.34 & 0.97 & 805 & \\
\hline $212 \mathrm{H}-010901-2232$ & 9.20 & 8.93 & 0.27 & 0.77 & 960 & \\
\hline
\end{tabular}

Calculation of the training MCO void volume based on physical dimensions is presented below.

Void volume empty $\mathrm{MCO}=1000 \mathrm{~L}$

Volume of empty fuel basket $=28.3 \mathrm{~L}$

The volume of the empty fuel basket was derived from density of basket material and weight of basket. Six empty fuel baskets are inside the training MCO.

Volume of six empty fuel baskets $=6 \times 28.3 \mathrm{~L}=170 \mathrm{~L}$

Void volume training $\mathrm{MCO}=$ Volume empty $\mathrm{MCO}$ - Volume empty fuel baskets

Void volume training $\mathrm{MCO}=1000 \mathrm{~L}-170 \mathrm{~L}=830 \mathrm{~L}$

\section{A.3 Calculate MCO Gas Pressure Based on MCO Void Volume}

The MCO gas pressure is calculated from the void volume and pressure information in Section A. 2 at constant temperature. Equation A-13 relates the observed initial pressures and volumes of the combined training $\mathrm{MCO}$ and sample system lines (between process valve operator and surge valve MCO-V-151 to the observed final pressure and volumes at the same temperature. (see Figure A-1)

$V_{M C O} \times P_{M C O}+V_{S S 1} \times P_{S S}=V_{M C O} \times P_{M C O 1}+V_{S S 1} L \times P_{M C O 1}$

Substituting solving Equation A-13 for $\mathrm{P}_{\mathrm{MCO}}$ gives equation A-14.

$\mathrm{P}_{\mathrm{MCO}}=\left[\mathrm{P}_{\mathrm{MCOI}} \mathrm{x}\left(\mathrm{V}_{\mathrm{MCO}}+7.2 \mathrm{~L}\right)-7.2 \mathrm{LP} \mathrm{SS}_{\mathrm{SS}}\right] /\left(\mathrm{V}_{\mathrm{MCO}}\right)$

Where:

$\mathrm{P}_{\mathrm{MCO}}$ is actual gas pressure of $\mathrm{MCO}$, psia

$\mathrm{P}_{\mathrm{MCO} 1}$ is gas pressure of training MCO as measured on PIT-721 with valve operator open and MCO-V-151 closed, psia. 
$\mathrm{P}_{\mathrm{MCO} 2}$ is gas pressure of training $\mathrm{MCO}$ as measured on PIT-721 with valve operator open, MCO-V-151 open, and MCO-V-154 closed, psia (Not used in Equation A-13 but value shown in Table A-11 for continuity).

$\mathrm{V}_{\mathrm{MCO}}$ is training $\mathrm{MCO}$ void volume, $\mathrm{L}$.

$\mathrm{V}_{\mathrm{SS} 1}$ is void volume between Port 2 valve operator and $\mathrm{MCO}-\mathrm{V}-151 \cong 7.2 \mathrm{~L}$

$\mathrm{P}_{\mathrm{SS}}$ is gas pressure of residual helium blank in sample system before addition of training MCO gas as measured on PIT-721, psia.

Equations A-15 and A-16 show an example calculation based on MCO Cart Sample $212 \mathrm{H}-010702-2235$ (see Table A-10). Table A-1 1 lists the estimated actual gas pressures of the training $\mathrm{MCO}$ at constant temperature. The results show there is less than 0.1-psi pressure differences between the empirical gas pressure of the $\mathrm{MCO}\left(\mathrm{P}_{\mathrm{MCO}}\right)$ and the gas pressure as measured in the sample cart on PIT-721 with MCO-V-151 closed ( $\left.\mathrm{P}_{\mathrm{MCO}}\right)$.

$$
\begin{aligned}
& P_{M C O}=[(9.94+14.7 \text { psia }) \times(805 \mathrm{~L}+7.2 \mathrm{~L})-7.2 \mathrm{~L} \times(0.97+14.7 \mathrm{psia})] / 805 \mathrm{~L}=24.7 \mathrm{psia} \\
& \mathrm{P}_{\mathrm{MCO}}=24.7 \mathrm{psia}-14.7 \mathrm{psia}=10.0 \mathrm{psig}
\end{aligned}
$$

\begin{tabular}{|c|c|c|c|c|c|}
\hline \multirow{2}{*}{ MCO Cart Sample } & \multicolumn{3}{|c|}{ MGO Pressure, psig } & $\begin{array}{l}\text { Sample System Residual } \\
\text { Helium Pressure, psig }\end{array}$ & $\begin{array}{l}\text { MeO Void Vol, I } \\
\text { (Ideal Gas Eaw) }\end{array}$ \\
\hline & $\mathrm{P}_{\mathrm{MCO}}$ & $\mathbf{P}_{\mathrm{MCO} 1}$ & $\mathrm{P}_{\mathrm{MCO} 2}$ & $\mathbf{P}_{\mathrm{SS}}$ & $\mathrm{V}_{\mathrm{MCO}}$ \\
\hline $212 \mathrm{H}-010402-1143$ & $\mathrm{~N} / \mathrm{A}$ & 10.15 & 9.81 & $\mathrm{~N} / \mathrm{A}$ & N/A \\
\hline $212 \mathrm{H}-010702-2235$ & 10.0 & 9.94 & 9.60 & 0.97 & 805 \\
\hline $212 \mathrm{H}-010901-2232$ & 9.26 & 9.20 & 8.93 & 0.77 & 960 \\
\hline
\end{tabular}

Table A-11: Pressure of Training MCO Based on Ideal Gas Law

\section{A.4 Calculate Gas Leakage Rate for Pressure Decay Test}

The TSR requires 75-psig pressure decay test of the MCO valve operator and MCO gas supply line inside sample hood BARR-002 within one hour prior to opening the valve operator

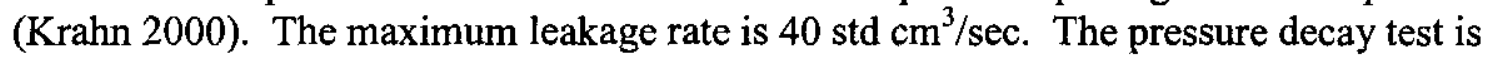
performed on the line between the process valve operator and surge valve MCO-V-151 and uses PIT-721 for pressure measurement. The following calculation is the basis of the maximum 5-psi pressure loss $(\Delta \mathrm{P})$ criteria over a 10 minute hold period on the line between the process valve operator and surge valve $\mathrm{MCO}-\mathrm{V}-151\left(\mathrm{~V}_{\mathrm{SS} 1} \cong 7.2 \mathrm{~L}\right.$, see Figure $\left.\mathrm{A}-1\right)$. Gas temperature is based on operating deck temperature of $62^{\circ} \mathrm{F}\left(16.7^{\circ} \mathrm{C}\right)$.

$\Delta \mathrm{n} \mathrm{g} \mathrm{mole} / \mathrm{sec}=\Delta \mathrm{PV} \mathrm{SSl}_{1} /(\mathrm{RT} 600 \mathrm{sec})$

$\Delta \mathrm{n}=(5 \mathrm{psi} \times 7.2 \mathrm{~L}) /\left(0.082 \mathrm{~L} \mathrm{~atm} / \mathrm{g}\right.$ mole $\left.{ }^{\circ} \mathrm{K} \times 289.8^{\circ} \mathrm{K} \times 14.7 \mathrm{psia} / \mathrm{atm} \times 600 \mathrm{sec}\right)$

$\Delta \mathrm{n}=1.72 \mathrm{E}-04 \mathrm{~g} \mathrm{~mole} / \mathrm{sec}$ 
Leakage rate based on ideal gas g mole volume of $22,400 \mathrm{~cm}^{3} / \mathrm{g}$ mole at standard temperature and pressure is shown in Equation A-20.

Line leakage rate $=\left(22,400 \mathrm{~cm}^{3} / \mathrm{g}\right.$ mole $) \times 1.72 \mathrm{E}-04 \mathrm{~g} \mathrm{~mole} / \mathrm{sec}=3.8 \mathrm{std} \mathrm{cm} / \mathrm{sec}$

Therefore, line leakage rate based on the 5-psi pressure drop is well below maximum allowable rate of $40 \mathrm{std} \mathrm{cm}^{3} / \mathrm{sec}$. 


\section{APPENDIX B}

\section{PACIFIC NORTHWEST NATIONAL LABORATORY GAS SPECIES ANALYSIS SAMPLE RESULT TRANSMITTAL LETTERS}

Letter Number 43469-L01 December 18,2001

Letter Number 43469-L02 January 7, 2002

Letter Number 43469-L03 January 11,2002

Letter Number 43469-L04 January 11, 2002

Letter Number 43469-L05 January 17, 2002
Page B-2 to B-23

Page B-24 to B-43

Page B-44 to B-62

Page B-63 to B-81

Page B-82 to B-104 


\section{Pacific Northwest National Laboratory}

December 18, 2001

Frank W. Moore

Fluor Hanford, Inc.

PO Box 1000

Richland, WA 99352

Dear Mr. Moore:

TRANSMITTAL OF REPORT 43469-RPT01, "GAS SPECIES ANALYSIS OF SAMPLES FROM THE CANISTER STORAGE BUILDING RECEIVED BY PNNL ON DECEMBER 13, 2001"

Reference: $\quad$ Statement of Work "Analysis of Gas Samples from the Spent Nuclear Fuel (SNF)

Canister Storage (CSB) Facility" transmitted to PNNL on October 26, 2001, accompanying contract 11979-36 (PNNL Project 43469).

Attached please find a copy of report 43469-RPT01, "Gas Species Analysis of Samples from the Canister Storage Building Received by PNNL on December 13, 2001." The samples described in this report were received by PNNL on December 13, 2001, and preliminary results were transmitted on December 13, 2001. The attached report is the final deliverable associated with these samples.

The sampling media used to obtain these samples were provided by CSB staff. Therefore, PNNL did not perform a cylinder cleaning check prior to obtaining samples. No cylinder cleaning documentation is included in the attached report.

Ail analyses performed and results reported in the attached document were conducted in compliance with OCRWM standards. This data has been reviewed and determined to be OCRWM-compliant.

Radiochemical Processing Laboratory (RPL) sample identification number used in this report was assigned as follows:

\begin{tabular}{|c|c|c|}
\hline RPL Sample ID & Client Sample ID & Client Sample Description \\
\hline $02-00899$ & $212 \mathrm{H} \cdot 121201-1348$ & He Gas Sample \\
\hline $02-00900$ & $212 \mathrm{H}-121201-2156$ & He Gas Sample \\
\hline $02-00901$ & $212 \mathrm{H}-121201-2243$ & MCO Gas Sample \\
\hline
\end{tabular}

If you have any question, please give me a call on $372-4828$.

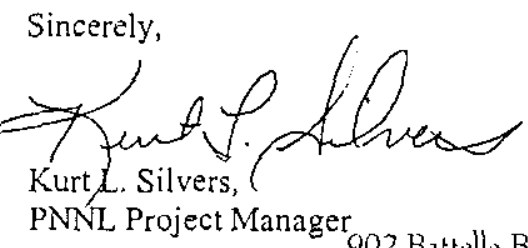

PNNL Project Manager

902 Battelle Boulevard • P.O. Box $999 \cdot$ Richland, WA 99352 
Frank W. Moore

December 18, 2001

Page 2

Attachment

E Biebesheimer, FH (summary only)

MS Busch, FH (summary only)

DR Duncan, FH (full data package)

SL Moore, FH (summary only)

DW Smith, FH (full data package)

GD Bazinet, NHC (surmmary only)

JP Sloughter, NHC (summary only)

SJ Bos, PNNL (full data package) AM Lewis, PNNL (summary only)

BM Thornton, PNNL (summary only)

43469 project file

$:$ 
Gas Species Analysis of Samples from the Canister Storage Building Received by PNNL on December 13, 2001

43469-RPT01, Rev. 0

December 18, 2001

Pacific Northwest National Laboratory 
Gas Species Analysis of Samples from the Canister Storage Building Received by PNNL on December 13, 2001

43469-RPT01, Rev. 0

Sample Analysis Letter

December 18, 2001

Pacific Northwest National Laboratory 


\section{ริง Battelle}

... Putting Technology To Work

Dale December 14, 2001

To Kurt Silvers

From

Stan Bos

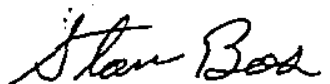

Subject Canister Storage Building gas sample analysis

\author{
43469 \\ Project No. $420+7$.
}

Internal Distribution

File/LB

Gas species analyses of samples, taken at the Canister Storage Building, on December 12, 2001 , have been completed. A report detailing the gas species detected is attached. Analysis was performed using the Finnigan MAT-271 (WC38625) high sensitivity quantitative mass spectrometer. The sensitivity of the instrument is checked daily prior to use with high purity N2 gas and two air standards are run weekly to insure the instrument is operating correctly. The samples were assigned RPL sequence numbers 02 00899 through 02-00901.

This analysis was performed, and the report prepared following PNNL quality assurance plan Nuclear Quality Assurance Requirements and Description (NQARD). NQARD has

$\checkmark$ been evaluated and found to be in conformance with the Office of Civilian Radioactive Waste Management (OCRWM) QA Program. The data in this report is OCRWM QARD Qualified Data.

PNNL project 43469 has setup for document and financial control of the sample analyses. Sample reports and data sheets are stored in the project RIDS located in ETB room 2619. Sample analyses are charged to work package F29087.

If you have any questions please contact Stan Bos at 376-5384.

Concurrence

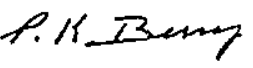
$12 / 14101$ 


\title{
Gas Species Analysis of Samples from the Canister Storage Building Received by PNNL on December 13, 2001
}

\author{
43469-RPT01, Rev. 0
}

\section{Gas Analysis Summary Results}

December 18, 2001

\section{Pacific Northwest National Laboratory}




\section{Pacific Northwest National Laboratory}

From: $\quad 325$ Gas \& Isolopic Mass Spectrometry

Phone: $\quad$ (509) 376-5384/mail slot P7-22

Date: December 14.2001

- Subject: Gas Species Analysis

To:

Kurt silvers :

Analytical procedure: PNNL-98523-284 rev 0 Laboratory Record Book $56998 \quad$ Page 136

Measurement and test equipment WC38625

Sample Id.

Analysis Date:

Log-in No.

Argon

Carbon dioxide

Carbon monoxide

Helium

Hydrogen

Neon

Nitrogen

Oxygen

Nitrous oxide

Other nitrogen oxides

Total Hydrocarbon

Comments

Sample Id.

Aralysis Date:

Log-in No.

Argon

Carbon dioxide

Carbon monoxide

Helium

Hydrogen

Neon

Nitrogen

Oxygen

Nitrous oxide

Other nitrogen oxides

Tolal Hydrocarbon

Comments
212H-121201-1348

December 13, 2001

02-00899

\begin{tabular}{|c|c|c|}
\hline $\begin{array}{l}\text { Mole } \\
\text { Percen }\end{array}$ & $\begin{array}{l}\text { Estimate of } \\
\text { Precision }\end{array}$ & PPM \\
\hline 0.005 & \pm 0.001 & 50 \\
\hline$<0.001$ & \pm 0 & $<10$ \\
\hline $\begin{array}{l}<0.01 \\
99.5\end{array}$ & $\begin{array}{l} \pm 0 \\
\pm 0.1\end{array}$ & $<100$ \\
\hline$<0.001$ & \pm 0 & $<10$ \\
\hline$<0.001$ & \pm 0 & $<10$ \\
\hline 0.413 & \pm 0.008 & 4130 \\
\hline 0.092 & \pm 0.002 & 920 \\
\hline$<0.001$ & \pm 0 & $<10$ \\
\hline$<0.001$ & \pm 0 & $<10$ \\
\hline$<0.001$ & \pm 0 & $<10$ \\
\hline
\end{tabular}

Water $<1000 \mathrm{ppm}$

212H-121201-2156

December 13, 2001

02-00900

$\begin{array}{cc}\text { Mole Estimate of } & \text { PPM } \\ \text { Percent } & \text { Precision } \\ & \\ <0.001 \pm 0 & \\ <0.001 \pm 0 & <10 \\ <0.01 \pm 0 & <100 \\ 99.99 \pm 0.01 & \\ <0.001 \pm 0 & <10 \\ <0.001 \pm 0 & <10 \\ 0.009 \pm 0.001 & 90 \\ 0.002 \pm 0.001 & 20 \\ <0.001 \pm 0 & <10 \\ <0.001 \pm 0 & <10 \\ <0.001 \pm 0 & <10\end{array}$

Water $<1000 \mathrm{ppm}$ 
Spent Nuclear Fuel Project Canister Storage Building

\section{Pacific Northwest National Laboratory}

From: $\quad 325$ Gas \& Isotopic Mass Spectrometry

Phone: $\quad$ (509) 376-5384/mail slot P7-22

Date:

December 14, 2001

- Subject: Gas Species Analysis

To:

Kurt silvers :

Analytical procedure: PNNL-98523-284 rev 0 Laboratory Record Book $56998 \quad$ Page

Measurement and test equipment WC38625

Sample Id.

Analysis Date:

$\log$-in No.

$212 \mathrm{H}-121201-2243$

December 13, 2001

02-00901

Argon

Carbon dioxide

Carbon monoxide

Helium

Hydrogen

Neon

Nitrogen

Oxygen

Nitrous oxide

Other nitrogen oxides

Total Hydrocarbon

Comments
Water $<1000 \mathrm{ppm}$

$\begin{array}{rl}\begin{array}{r}\text { Mole } \\ \text { Percent }\end{array} \text { Estimate of } & \text { PPM } \\ & \\ 0.006 \pm 0.001 & 60 \\ <0.001 \pm 0 & <10 \\ <0.01 \pm 0 & <100 \\ 99.4 \pm 0.1 & \\ <0.001 \pm 0 & <10 \\ <0.001 \pm 0 & <10 \\ 0.5 \pm 0.01 & 5000 \\ 0.126 \pm 0.003 & 1260 \\ <0.001 \pm 0 & <10 \\ <0.001 \pm 0 & <10 \\ <0.001 \pm 0 & <10\end{array}$

60

$<100$

$<10$

5000

1260

$<10$

$<10$ 


\section{Gas Species Analysis of Samples from the Canister Storage Building Received by PNNL on December 13, 2001}

43469-RPT01, Rev. 0

Chain-of-Custody Form

December 18, 2001

Pacific Northwest National Laboratory

7

B-10 


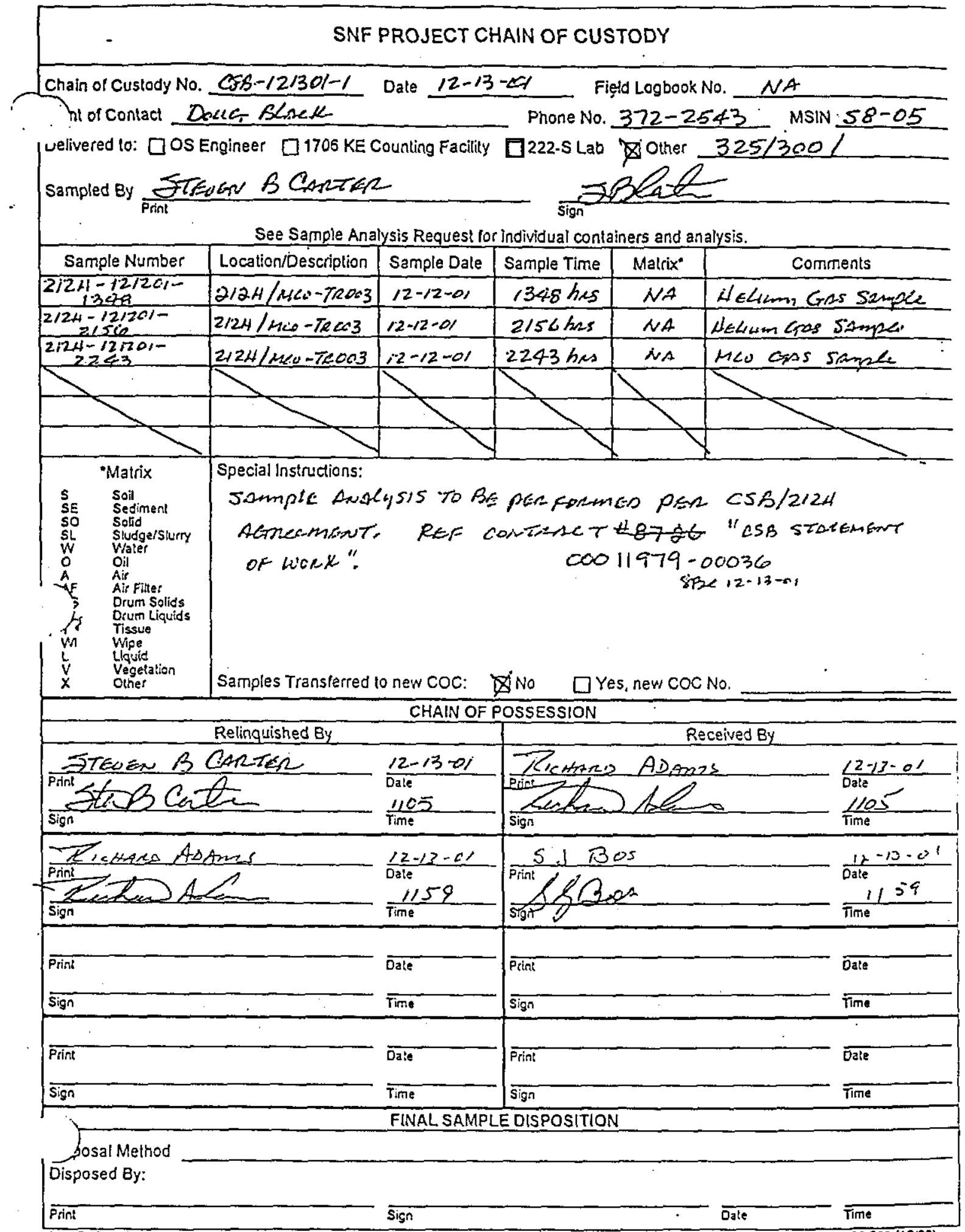




\section{Gas Species Analysis of Samples from the Canister Storage Building Received by PNNL on December 13, 2001 \\ 43469-RPT01, Rev. 0}

\section{Analytical Services Request}

December 18, 2001

Pacific Northwest National Laboratory 


\section{Analytical Service Request (ASR)}

(Information on this COVER PAGE is applicable to all samples submitced under this ASR)

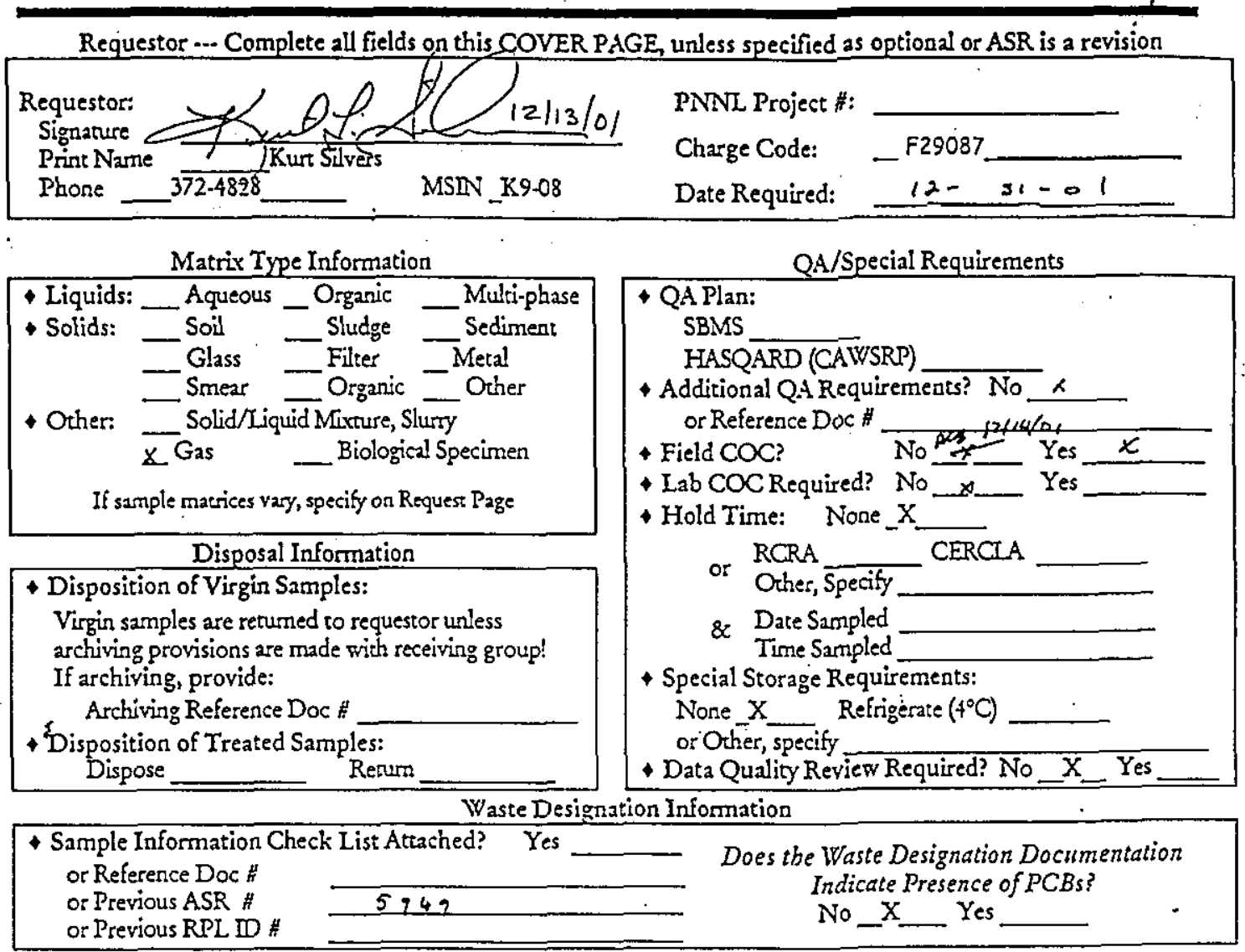

Additional or Special Instructions

Send Report To _KurI silver $\quad$ Phone $372-4228$

Preliminary results requested, as available? No ___ Yes ___ (requesting preliminary results may increase cost)

Receiving and Login Information (to be completed by laboratory staff)

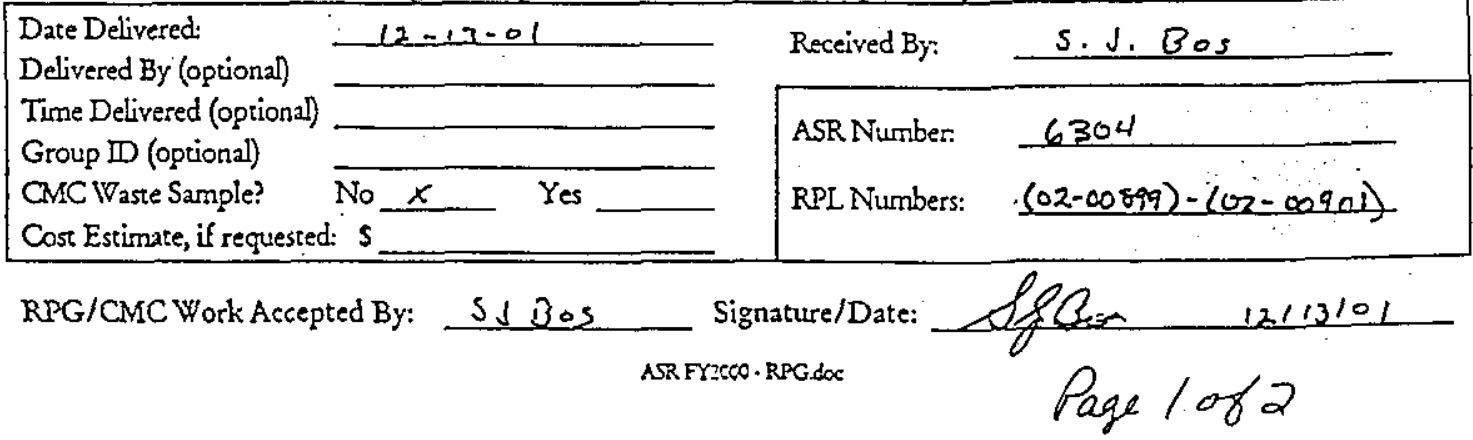




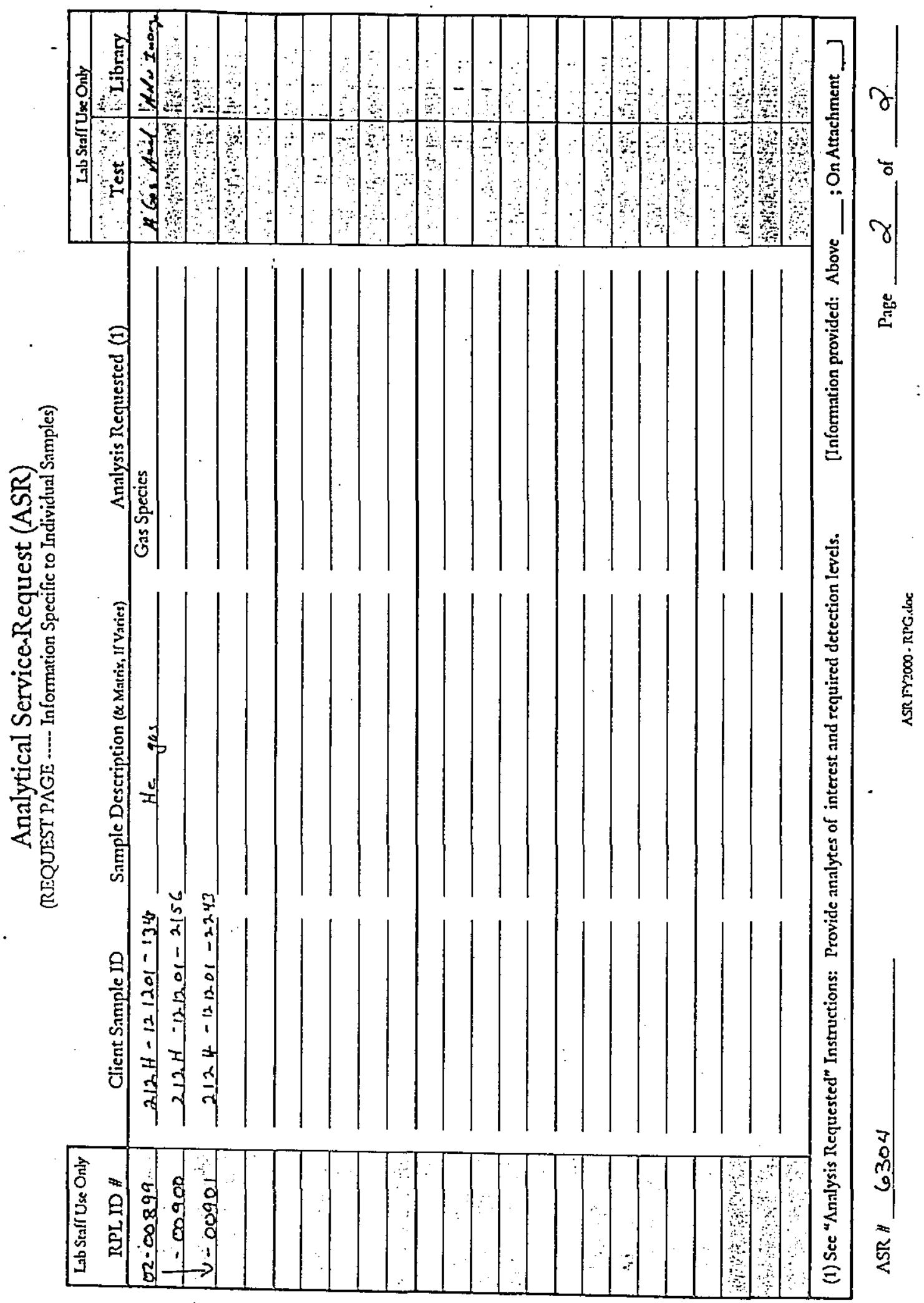




\title{
Gas Species Analysis of Samples from the Canister Storage Building Received by PNNL on December 13, 2001
}

43469-RPT01, Rev. 0

\author{
Quality Control Check
}

December 18, 2001

\section{Pacific Northwest National Laboratory}




\section{Pacific Northwest National Laboratory}

From: 325 Gas \& Isotopic Mass Spectrometry

Phone: (509) 376-3358 / mail slot P7-22

Date: December 10, 2001

Subject: Arr standards from Finnigan MAT - 271 Mass Spectrometer

Analytical procedure: PNNL - 98523 - 284 Rev. 0

Laboratory Record Book 56998: Page 135

Measurement and test equipmen! WC38625

Accepted values for the composition of air:

$\begin{array}{lc} & \text { Mole percent } \\ \text { Argon } & 0.934 \\ \text { Nitrogen } & 78.08 \\ \text { Oxygen } & 20.95\end{array}$

Analyzed Values:

Analysis Date: December 10,2001

?

$\begin{array}{lc} & \text { Mole percent } \\ \text { Argon } & 0.938 \\ \text { Nitrogen } & 78.02 \\ \text { Oxygen } & 21.00\end{array}$

Analyzed Values:

Aralysis Date: December 10,2001

$\begin{array}{lc} & \text { Mole percen } \\ \text { Argon } & 0.937 \\ \text { Nitrogen } & 77.89 \\ \text { Oxygen } & 21.13\end{array}$

Instrument Background:

Background analyses are run daily prior to sample analyses. Trace amounts of hydrogen and/or water in the 0.1 to 0.2 millivolt range were the only species detected. The background spectra is subtracted from each sample spectra. 


\title{
Gas Species Analysis of Samples from the Canister Storage Building Received by PNNL on December 13, 2001
}

\author{
43469-RPT01, Rev. 0
}

Raw Instrument Data from Gas Analysis

December 18, 2001

Pacific Northwest National Laboratory 
Spent Nuclear Fuel Project Canister Storage Building Multi-Canister Overpack Sampling System Validation (OCRWM)

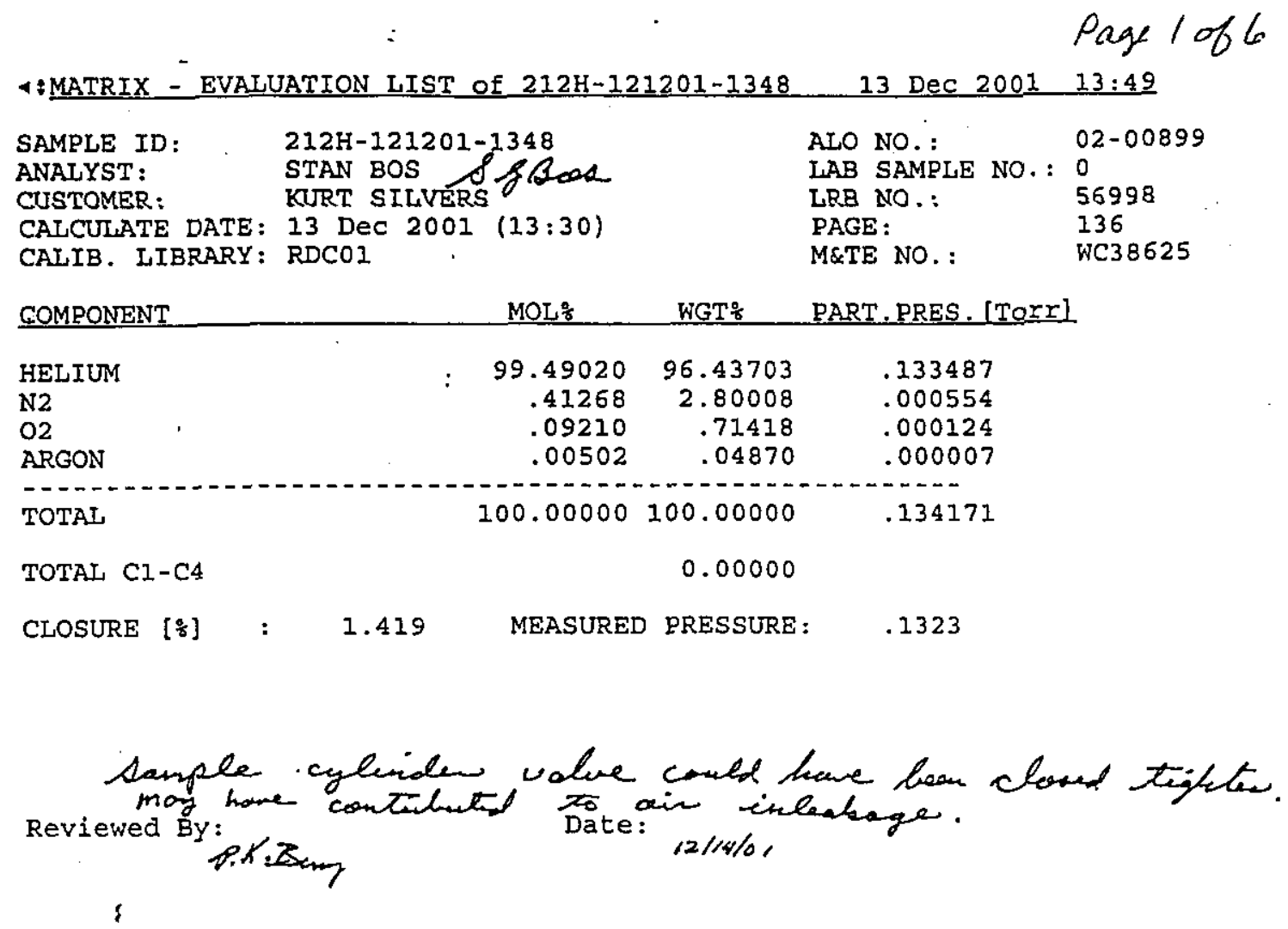




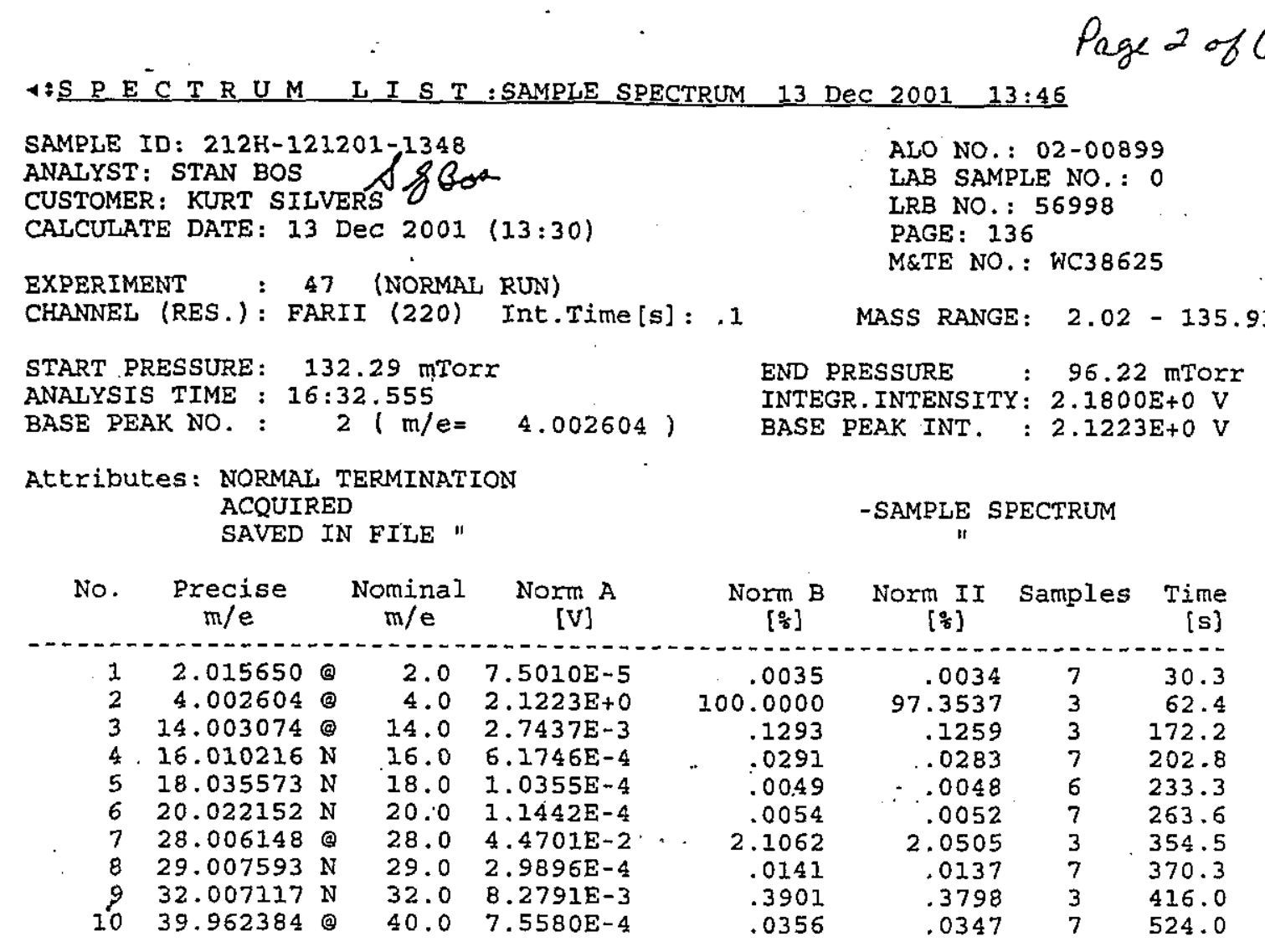

Reviewed By: P.K.S Date: 12/14/0, 


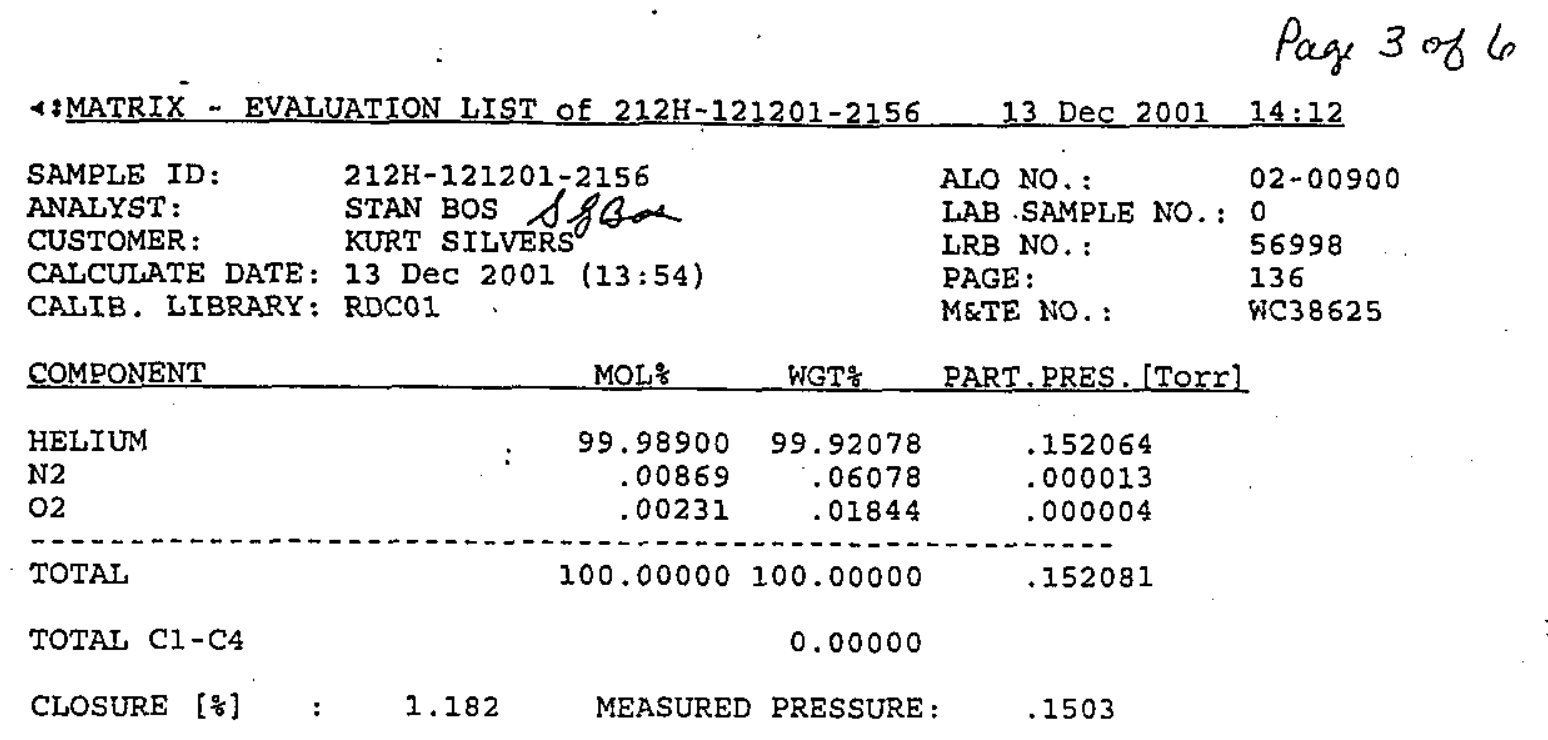

Reviewed BY: fixtBing Date: Iz/14lo, 
Spent Nuclear Fuel Project Canister Storage Building

Multi-Canister Overpack Sampling System Validation (OCRWM)

SNF-10618

Rev. 0

Page 4 of 6

$4 \pm S$ P E T T UM LIST SAMPLE SPECTRUM 13 DeC 2001 14:10

SAMPLE ID: $212 \mathrm{H}-121201-2156$
ANALYST: STAN BOS
CUSTOMER: KURT SILVERS $\mathrm{f}$ Go
CALCULATE DATE: 13 DEC 2001 (13:54)

EXPERIMENT : 47 (NORMAI RUN)

CHANNEL (RES.) : FARII (220) Int.Time[s]: .1

START RRESSURE: 150.3 mTORI

ANALYSIS TIME : $16: 19.758$

BASE PEAK NO. : $2(\mathrm{~m} / \mathrm{e}=4.002604)$

Attributes: NORMAL TERMINATION

ACQUIRED

SAVED IN FILE "
ALO NO.: $02-00900$

LAB SAMPLE NO.: 0

LRB NO : : 56998

PAGE: 136

M\&TE NO.: WC38625

MASS RANGE: $2.02-135.91$

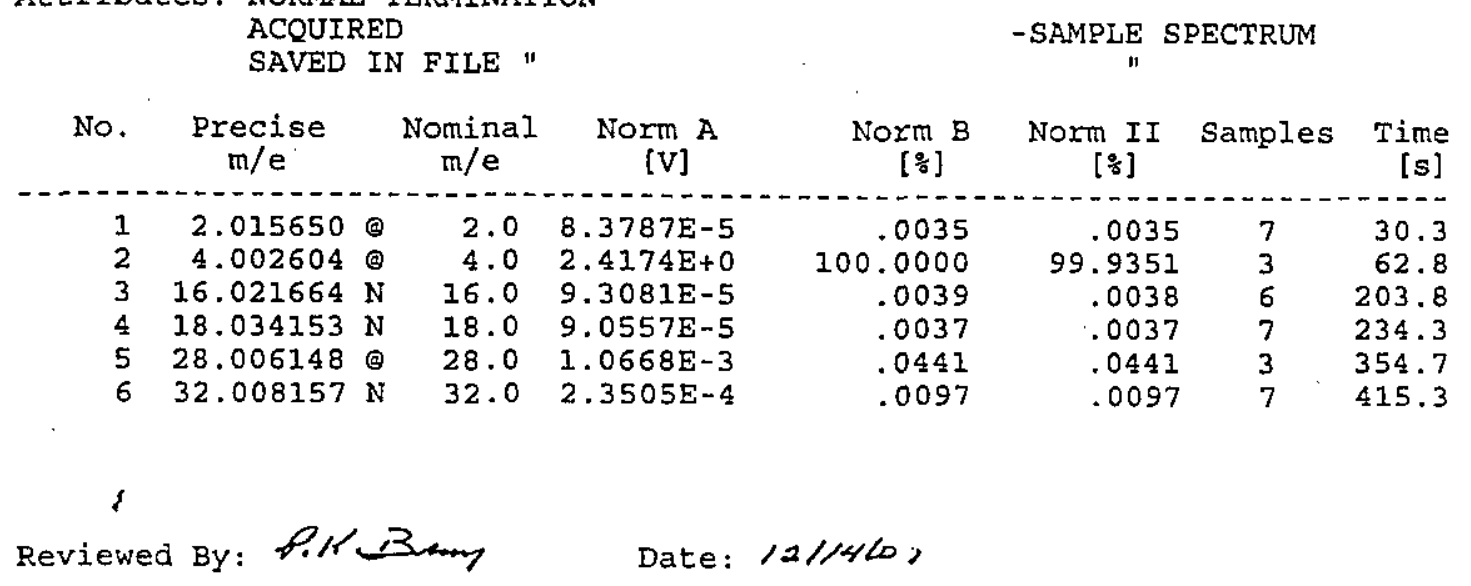

END PRESSURE : : 109.72 mTOY

INTEGR. INTENSITY: $2.4190 \mathrm{E}+0 \mathrm{~V}$

BASE PEAK INT. : $2.4174 \mathrm{E}+0 \mathrm{~V}$

-SAMPLE SPECTRUM

II Samples Time

]

0.3

3.8

234.3

354.7

415.3

Reviewed By: 


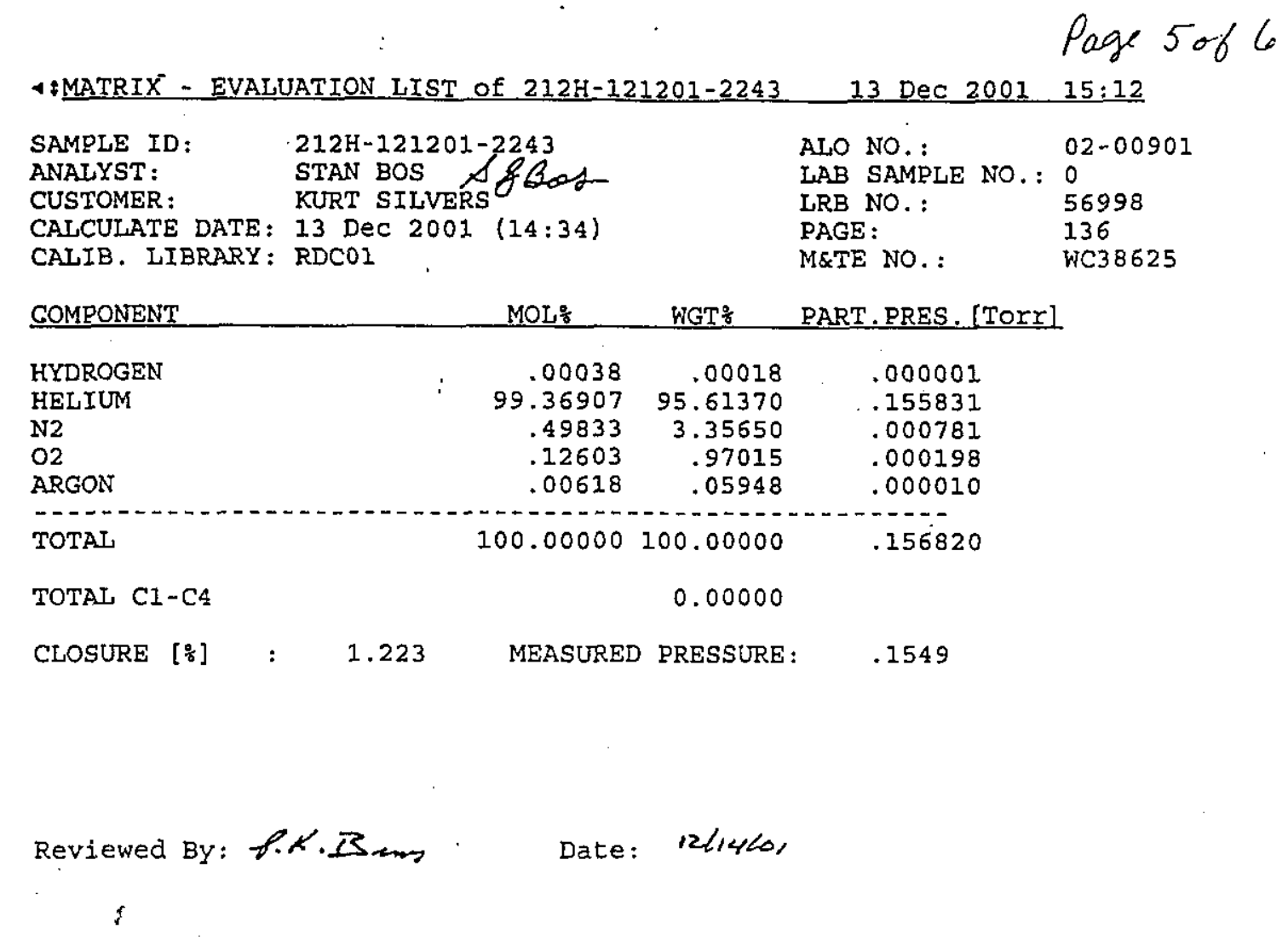


Spent Nuclear Fuel Project Canister Storage Building Multi-Canister Overpack Sampling System Validation (OCRWM)

SNF-10618

Rev. 0

$$
\text { Page } 6 \text { of } 6
$$

4 S PECTR UM L I S T :SAMPLE SPECTRUM 13 DEC 2001 14:51

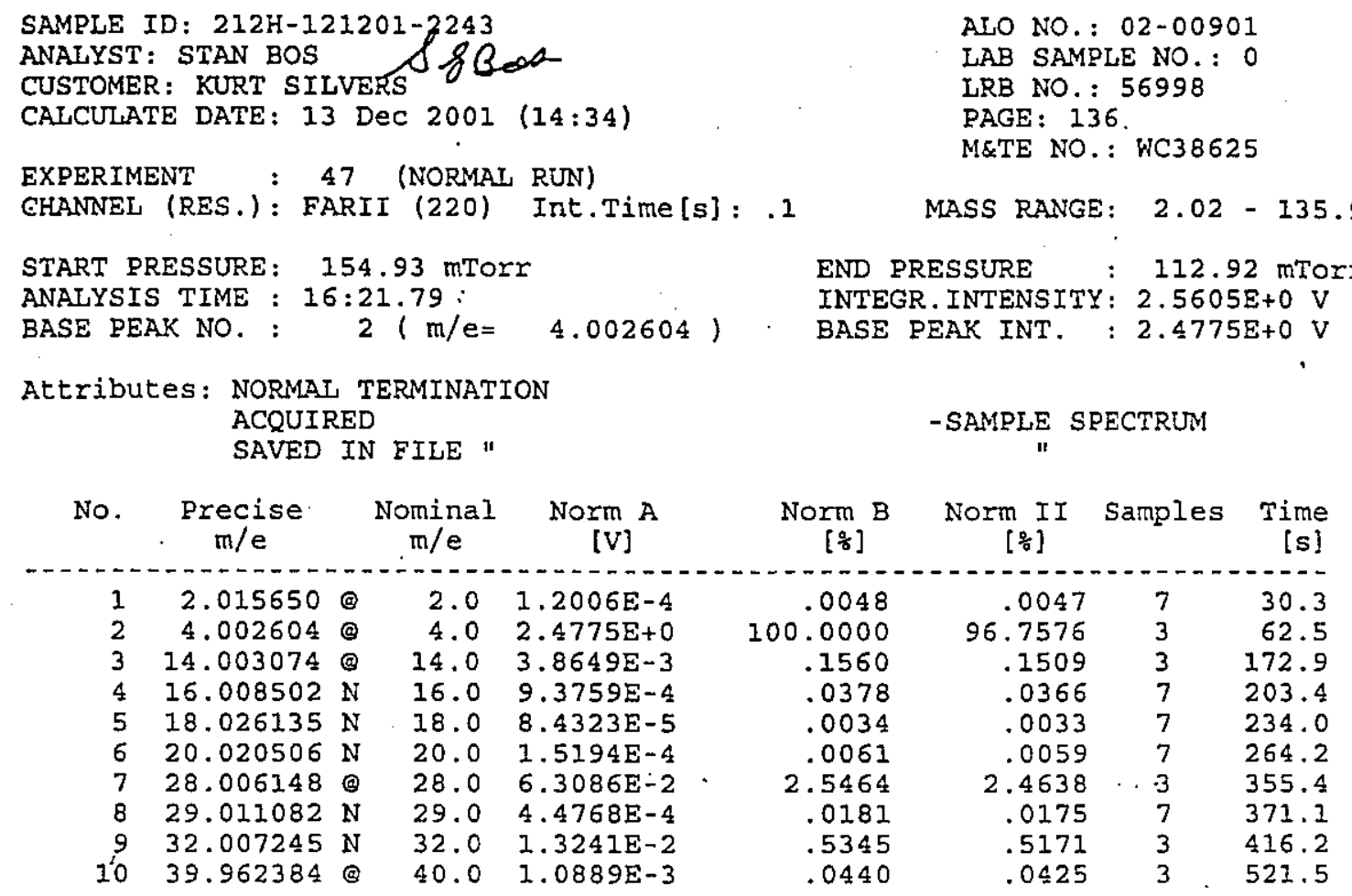

Reviewed By: P.r.B.m Date: $12 / 14 / 0$, 


\section{Pacific Northwest National Laboratory}

January 7, 2002

Frank W. Moore

Fluor Hanford, Inc.

PO Box 1000

Richland, WA 99352

Dear Mr. Moore:

TRANSMITTAL OF REPORT 43469-RPT02, "GAS SPECIES ANALYSIS OF SAMPLES FROM THE CANISTER STORAGE BUILDING RECEIVED BY PNNL ON DECEMBER 20, 2001”

Reference: $\quad$ Statement of Work "Analysis of Gas Samples from the Spent Nuclear Fuel (SNF)

Canister Storage (CSB) Facility" transmitted to PNNL on October 26, 2001, accompanying contract 11979-36 (PNNL Project 43469).

Attached please find a copy of report 43469-RPT02, "Gas Species Analysis of Samples from the Canister Storage Building Received by PNNL on December 20, 2001." The samples described in this report were received by PNNL on December 20,2001, and preliminary results were transmitted on December 20 , 2001. The attached report is the final deliverable associated with these samples.

All analyses performed and results reported in the attached document were conducted in compliance with OCRWM standards. This data has been reviewed and determined to be OCRWM-compliant.

Radiochemical Processing Laboratory (RPL) sample identification numbers used in this report were assigned as follows:

\begin{tabular}{|c|c|c|}
\hline RPL Sample ID & Client Sample ID & Client Sample Description \\
\hline $02-00973$ & $212 \mathrm{H}-121901-2332$ & MCO Gas Sample \\
\hline $02-00974$ & $212 \mathrm{H}-122001-1336$ & He Gas Sample \\
\hline
\end{tabular}

If you have any question, please give me a call on 372-4828.

Sincerely,

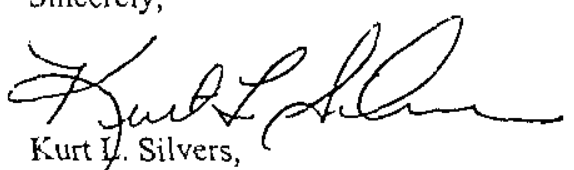

Kurt 1 . Silvers,

PNNt Project Manager

Attachment 
Spent Nuclear Fuel Project Canister Storage Building

Multi-Canister Overpack Sampling System Validation (OCRWM)

SNF-10618

Rev. 0

Frank W. Moore

January 7,2002

Page 2

CC: E Biebesheimer, FH (summary only)

MS Busch, FH (summary only)

DR Duncan, FH (full data package)

SL Moore, FH (summary only)

DW Smith, FH (full data package)

GD Bazinet, NHC (summary only)

JP Sloughter, NHC (summary only)

SJ Bos, PNNL (full data package)

AM Lewis, PNNL (summary only)

BM Thornton, PNNL (summary only)

43469 project file

4 


\section{Gas Species Analysis of Samples from the Canister Storage Building Received by PNNL on December 20, 2001}

43469-RPT02, Rev. 0

January 7, 2002

Pacific Northwest National Laboratory 
Gas Species Analysis of Samples from the Canister Storage Building Received by PNNL on December 20, 2001 43469-RPT02, Rev. 0

Sample Analysis Letter

January 7, 2002

\section{Pacific Northwest National Laboratory}


5. Battelle

... Putting Technology To Work

Date January 2, 2002

To Kurt Silvers

From Stan Bos stom Bos

Subjest Canister Storage Building gas sample analvsis

\section{9 ins $1 / 3 / 02$ \\ Project No.}

Interna! Discribution

File/LB

Gas species analyses of samples taken at the Canister Storage Building (CSB) on December 19 and 20,2001, have been completed. A report detailing the gas species detected is attached. Analysis was performed using the Finnigan MAT-271 (WC38625) high sensitivity quantitative mass spectrometer. The sensitivity of the instrument is checked daily prior to use with high purity N2 gas, and two air standards are run weekly to insure the instrument is operating correctly. The samples were assigned RPL sequence numbers 02-00973 through 02-00974.

Analysis of the evacuated sampler prior to taking the sample was not performed. CSB evacuates the sample cylinders before inletting the sample gas. Since this is a procedural step, a sampler cleaning analysis becomes unnecessary.

This analysis was performed and the report prepared following PNNL quality assurance plan Nuclear Quality Assurance Requirements and Description (NQARD). NQARD has been evaluated and found to be in conformance with the Office of Civilian Radioactive Waste Management (OCRWM) QA Program. The data in this report is OCRWM QARD Qualifted Data.

PNNL project 43469 has setup for document and financial control of the sample analyses. Sample reports and data sheets are stored in the project RIDS located in ETB room 2619. Sample analyses are charged to work package F29087.

If you have any questions please contact Stan Bos at 376-5384.

Concurrence P.Kezery 


\section{Gas Species Analysis of Samples from the Canister Storage Building Received by PNNL on December 20, 2001}

43469-RPT02, Rev. 0

Gas Analysis Summary Results

\section{$\because$}

January 7, 2002

Pacific Northwest National Laboratory 
Spent Nuclear Fuel Project Canister Storage Building

Multi-Canister Overpack Sampling System Validation (OCRWM)

SNF-10618

Rev. 0

\section{Pacific Northwest National Laboratory}

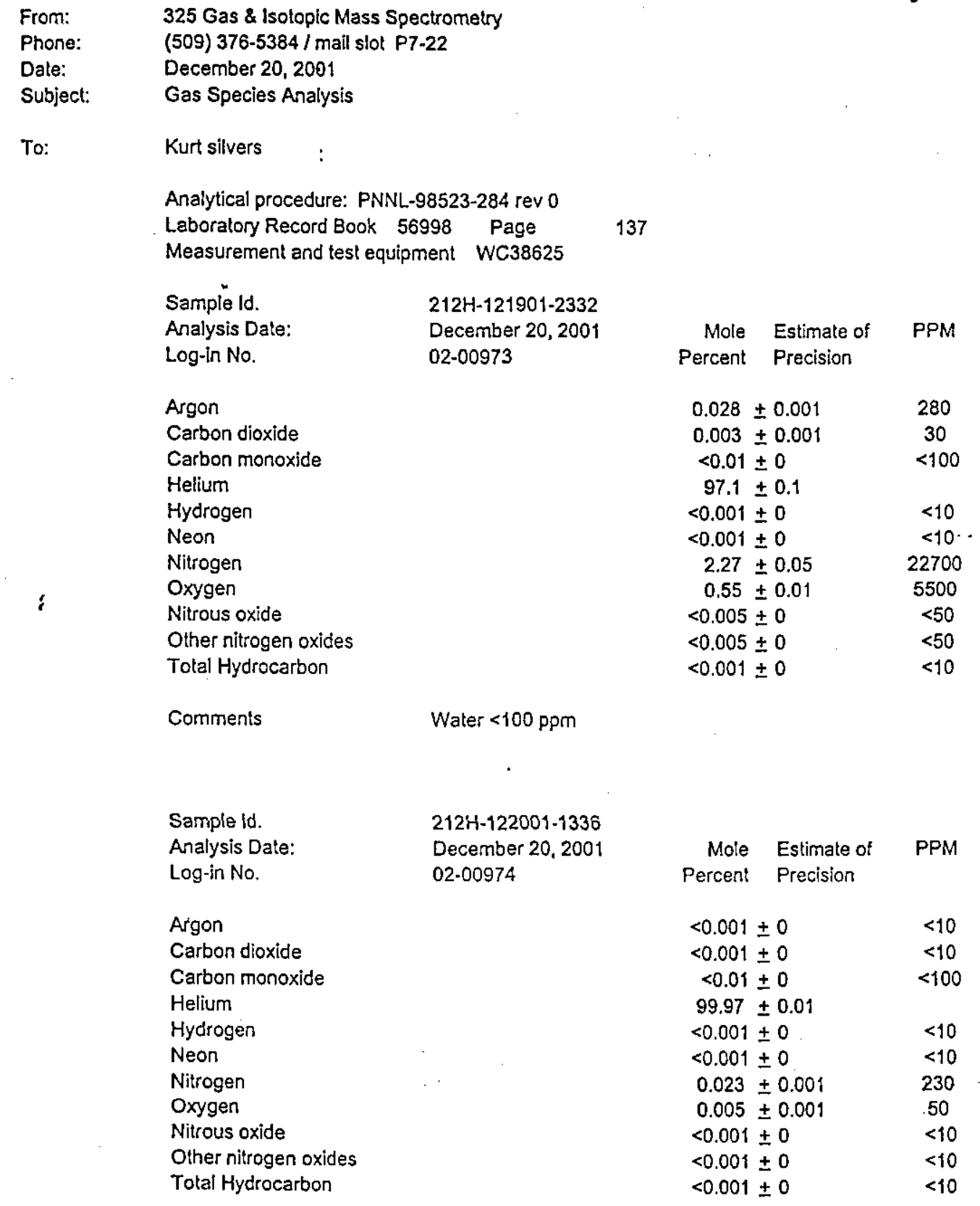

Comments Water $<100 \mathrm{ppm}$ 


\section{Gas Species Analysis of Samples from the Canister Storage Building Received by PNNL on December 20, 2001 \\ 43469-RPT02, Rev. 0}

\section{Chain-of-Custody Forms}

January 7, 2002

Pacific Northwest National Laboratory 
Spent Nuclear Fuel Project Canister Storage Building

Multi-Canister Overpack Sampling System Validation (OCRWM)

SNF-10618

Rev. 0

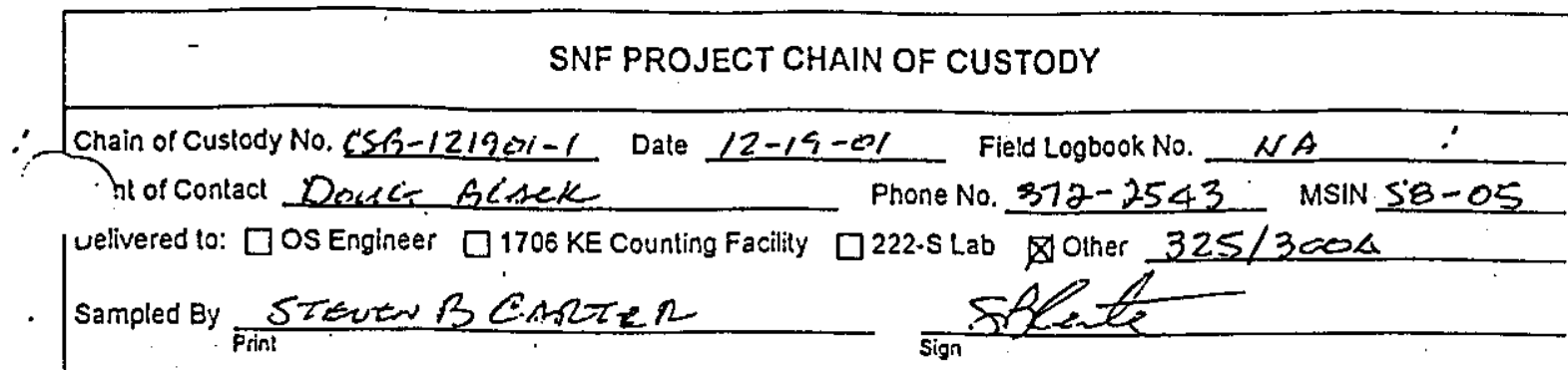

See Sample Analysis Request for individual containers and analysis.

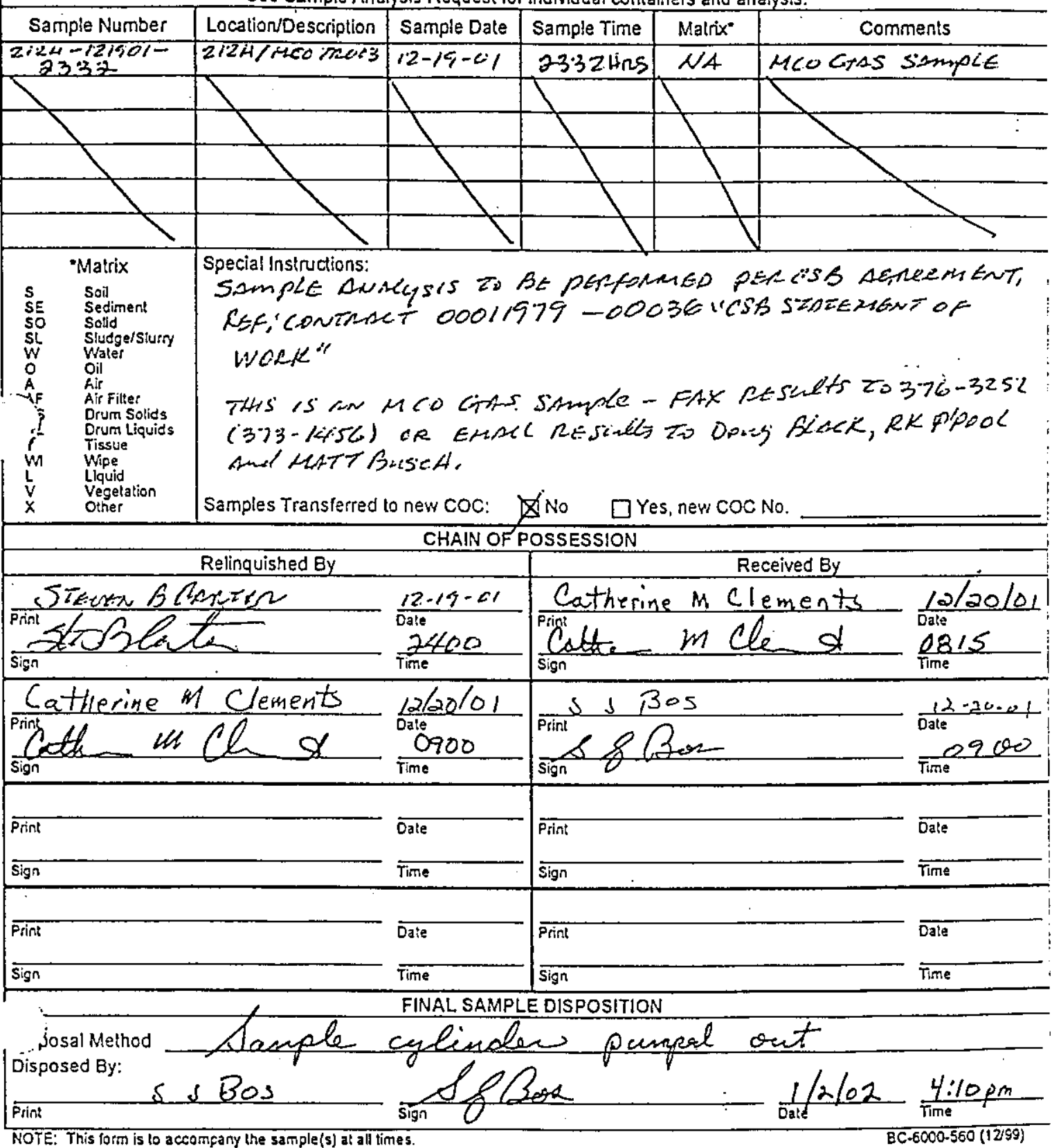




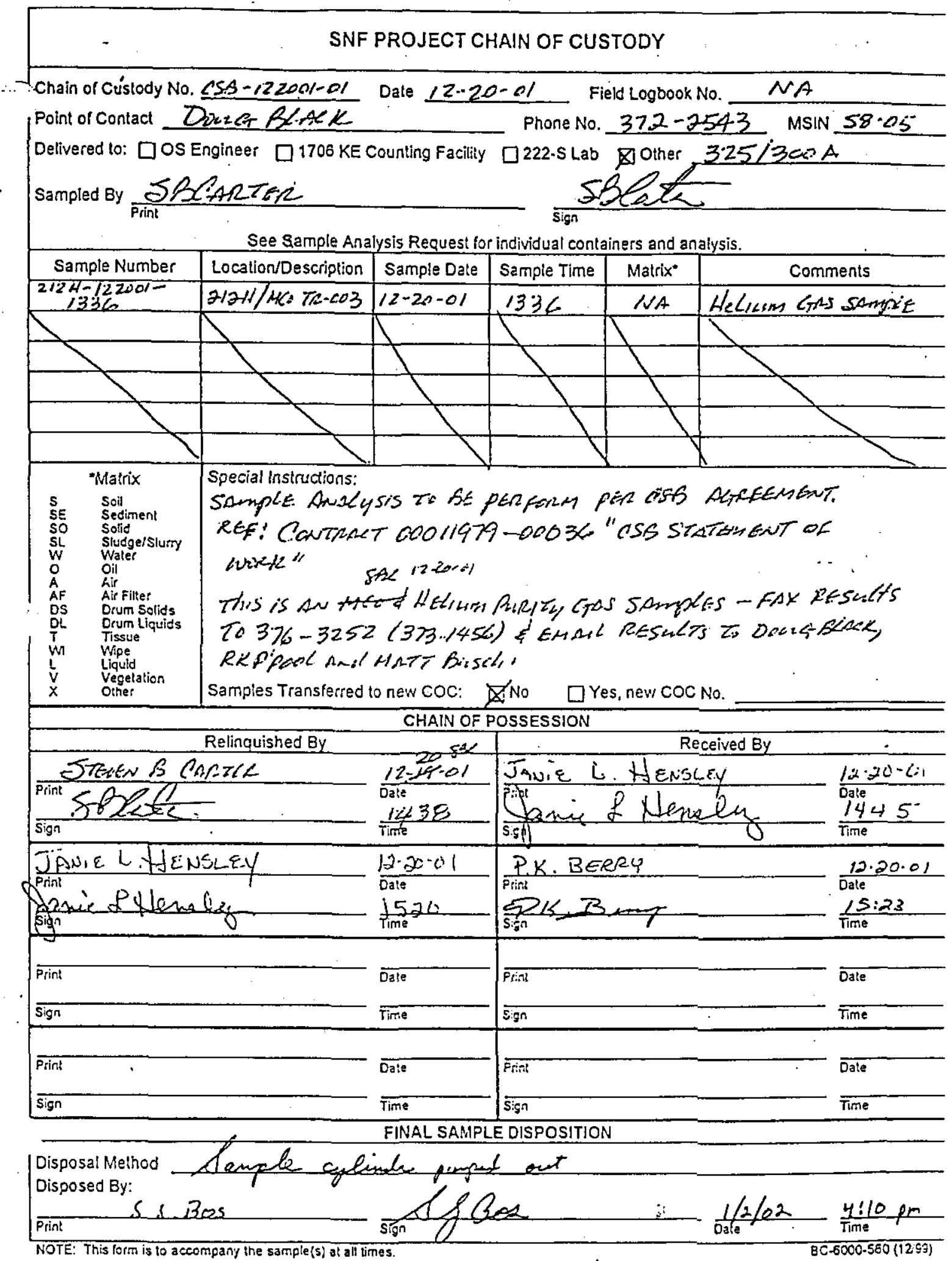




\section{Gas Species Analysis of Samples from the Canister Storage Building Received by PNNL on December 20, 2001 \\ 43469-RPT02, Rev. 0}

Analytical Services Request

January 7, 2002

Pacific Northwest National Laboratory 
Requestor -... Complete all fields on this COVER PAGE, unless specified as optional or ASR is a revision

\begin{tabular}{|c|c|c|c|c|}
\hline r. & & PNNL Project $\#$ : & 43469 & \\
\hline Print Name $/$ Kurt Silvers & $1-1=10$ & Charge Code: & $\ldots 29087$ & \\
\hline Phone $372-4828$ & MSIN K9.08 & Date Required: & $1-15-01$ & . \\
\hline
\end{tabular}

Matrix Type Information

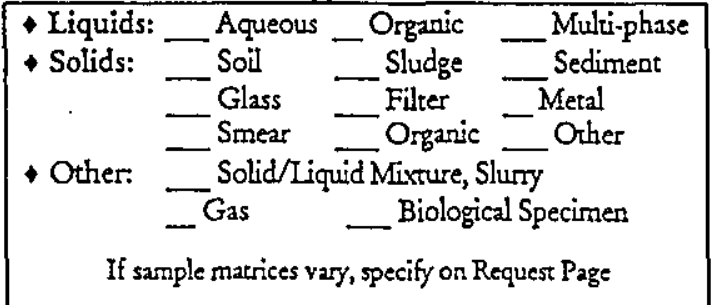
Disposal Information

+ Disposition of Virgin Samples:

Virgin samples are renurned to requestor unless archiving provisions are made with receiving group! If archiving, provide:

Archiving Reference Doc \#

+ Disposition of Treated Samples: Dispose
Return
QA/Special Requirements

QA Plan:
SBMS
HASQARD (CAWSRP)

- Additional QA Requirements? No or Reference Doc \#"

- Field COC? No

- Lab COC Required? No $X$

- Hold Time: None_X

or RCRA Other, Specify CERCLA Time Sampled

- Special Storage Requirements:

None $\mathrm{X}$ Refrigerate $\left(4^{\circ} \mathrm{C}\right)$ or Other, specify

- Data Quality Review Required? No X Yes

Waste Designation Information

\begin{tabular}{|l|c|}
\hline Sample Information Check List Attached? Yes_ & Does the Waste Designation Documentation \\
or Reference Doc \# \\
or Previous ASR \# \\
or Previous RPL D $\#$
\end{tabular}

Additional or Special Instructions

Send Report To KurT Silvers Phone $372-4828$

Preliminary results requested, as available? No ___ Yes ___ (requesting preliminary sesults may increase cost)

Receiving and Login Information (to be completed by laboratory staff)

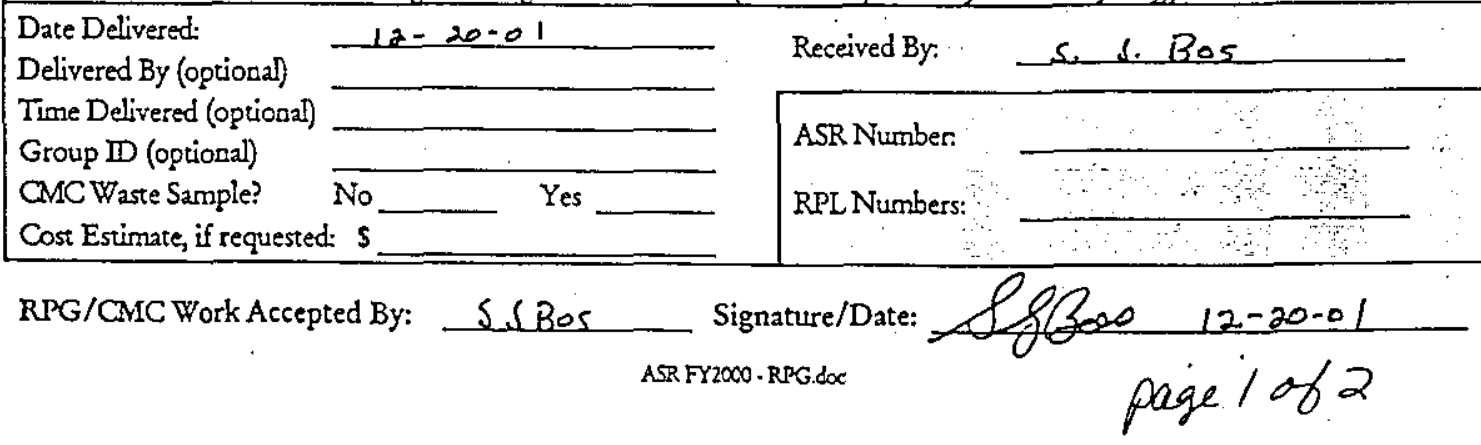




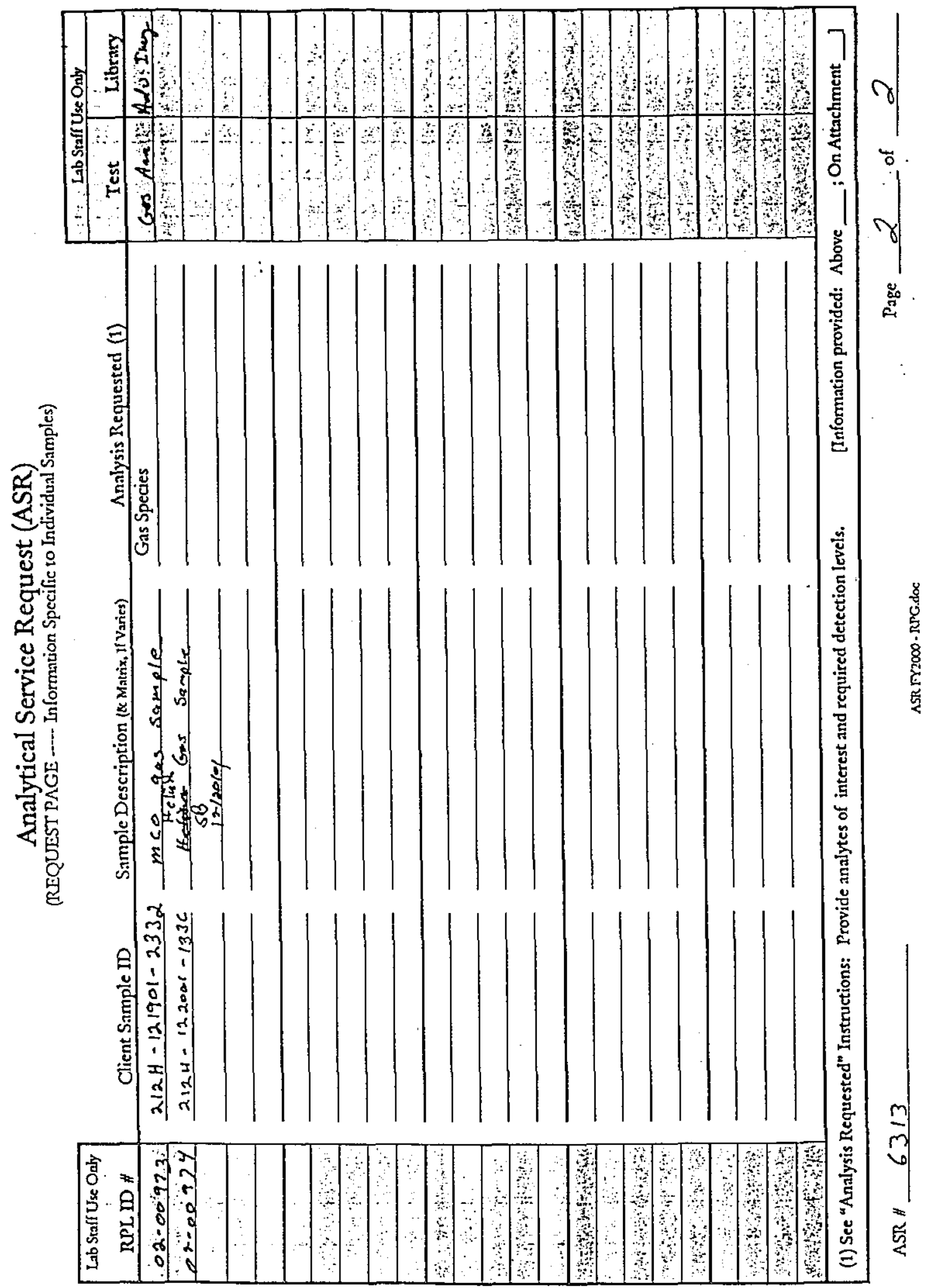




\title{
Gas Species Analysis of
} Samples from the Canister Storage Building Received by PNNL on December 20, 2001

\author{
43469-RPT02, Rev. 0
}

\section{Quality Control Check}

\section{January 7,2002}

\section{Pacific Northwest National Laboratory}




\section{Pacific Northwest National Laboratory}

From: 325 Gas \& Isotopic Mass Spectrometry

Phone: (509) 376-3358/ mail slot P7-22

Date: December 17, 2001

Subject: Air standards from Finnigan MAT - 271 Mass Spectrometer

Analytical procedure: PNNL - 98523 - 284 Rev. 0

Laboratory Record Book 56998: Page 136

Measurement and test equipment WC38625

Accepted values for the composition of air :

$\begin{array}{lc} & \text { Mole percent } \\ \text { Argon } & 0.934 \\ \text { Nitrogen } & 78.08 \\ \text { Oxygen } & 20.95\end{array}$

Analyzed Values:

Analysis Date: December 17,2001

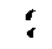

Mole percent

Argon

0.938

Nitrogen

78.10

Oxygen

20.92

Analyzed Values:

$\begin{array}{lc}\text { Analysis Date: } & \text { December } 17,2001 \\ & \text { Mole percent } \\ \text { Argon } & 0.937 \\ \text { Nitrogen } & 77.92 \\ \text { Oxygen } & 21.10\end{array}$

Instrument Background:

Background analyses are run daily prior to sample analyses. Trace amounts of hydrogen and/or water in the 0.1 to 0.2 millivolt range were the only species detected. The background spectra is subtracted from each sample spectra. 
January 7, 2002

\section{Pacific Northwest National Laboratory}


Spent Nuclear Fuel Project Canister Storage Building

Multi-Canister Overpack Sampling System Validation (OCRWM)

SNF-10618

Rev. 0

$$
\text { Page lof } 4
$$

4 MATRIX - EVALUATION LIST of 212H-121901-2332

20 Dec $2001 \quad 10: 18$

\begin{tabular}{|c|c|c|c|c|c|}
\hline $\begin{array}{l}\text { SAMPLE ID: } \\
\text { ANALYST: } \\
\text { CUSTOMER: } \\
\text { CALCULATE DATE: } \\
\text { CALIB. LIBRARY: }\end{array}$ & $\begin{array}{l}212 \mathrm{H}-121901 \\
\text { STAN BOS } \\
\text { CSB } \\
20 \text { DeC } 2001 \\
\text { RDC01 }\end{array}$ & $\begin{array}{l}-2332 \\
\text { J bot } \\
109: 39\rangle\end{array}$ & & $\begin{array}{l}\text { ALO NO.: } \\
\text { LAB SAMPLE NO.: } \\
\text { LRB NO.: } \\
\text { PAGE: } \\
\text { M\&TE NO.: }\end{array}$ & $\begin{array}{l}02-00973 \\
0 \\
56998 \\
137 \\
\text { WC38625 }\end{array}$ \\
\hline COMPONENT & & MOL & WGT: & PART . PRES . [TORY] & \\
\hline $\begin{array}{l}\text { HYDROGEN } \\
\text { HELIUM } \\
\text { N2 } \\
\text { O2 } \\
\text { ARGON } \\
\mathrm{CO} 2\end{array}$ & & $\begin{array}{r}.00044 \\
97.14806 \\
2.26745 \\
.55357 \\
.02750 \\
.00297\end{array}$ & $\begin{array}{r}.00019 \\
82.49898 \\
13.47878 \\
3.76080 \\
.23350 \\
.02775\end{array}$ & $\begin{array}{l}.000001 \\
.132800 \\
.003100 \\
.000757 \\
.000038 \\
.000004\end{array}$ & \\
\hline TOTAL & & 100.00000 & 100.00000 & .136698 & \\
\hline TOTAL C1-C4 & & & 0.00000 & & \\
\hline CLOSURE [\%] & 1.225 & MEASURED & PRESSURE & .1350 & \\
\hline
\end{tabular}

Reviewed By: PKAB Date: $1-z-02$ 


$$
\text { Page } 2 \text { of } 4
$$

$4: S$ P E T R U M IIST :SAMPLE SPECTRUM 20 DeC 2001 10:16

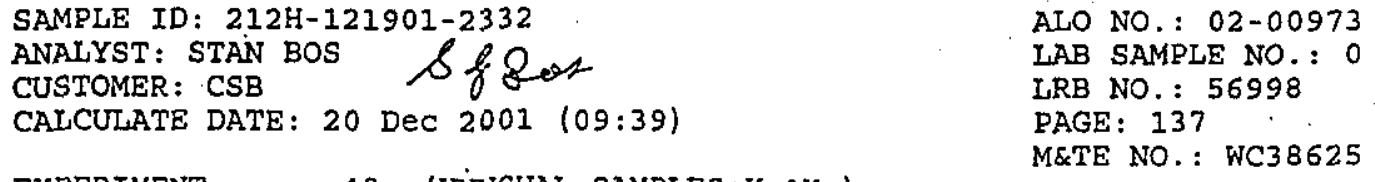

$\begin{array}{rrrrrrrr}1 & 2.015650 & 2.0 & 1.2814 \mathrm{E}-4 & .0062 & .0054 & 7 & 28.6 \\ 2 & 4.002604 \mathrm{~B} & 4.0 & 2.0569 \mathrm{E}+0 & 100.0000 & 86.6643 & 3 & 58.1 \\ 3 & 14.003074 \mathrm{Q} & 14.0 & 1.4976 \mathrm{E}-2 & .7281 & .6310 & 3 & 213.4 \\ 4 & 16.009739 \mathrm{~N} & 16.0 & 3.4059 \mathrm{E}-3 & .1656 & .1435 & 3 & 244.0 \\ 5 & 18.028387 \mathrm{~N} & 18.0 & 9.6444 \mathrm{E}-5 & .0047 & .0041 & 6 & 274.1 \\ 6 & 20.015790 \mathrm{~N} & 20.0 & 6.2117 \mathrm{E}-4 & .0302 & .0262 & 7 & 304.1 \\ 7 & 28.005148 \mathrm{Q} & 28.0 & 2.4182 \mathrm{E}-1 & 11.7563 & 10.1885 & 3 & 410.0 \\ 8 & 29.006535 \mathrm{~N} & 29.0 & 1.7774 \mathrm{E}-3 & .0864 & .0749 & 3 & 425.3 \\ 19 & 32.003505 \mathrm{~N} & 32.0 & 4.9015 \mathrm{E}-2 & 2.3829 & 2.0651 & 3 & 470.5 \\ 10 & 33.931466 \mathrm{~N} & 34.0 & 2.2232 \mathrm{E}-4 & .0108 & .0094 & 6 & 500.6 \\ 11 & 39.962384 \mathrm{O} & 40.0 & 4.0719 \mathrm{E}-3 & .1980 & .1716 & 3 & 590.6 \\ 12 & 44.013643 \mathrm{~N} & 44.0 & 3.8290 \mathrm{E}-4 & .0186 & .0161 & 6 & 651.0\end{array}$

Reviewed By: P.K.3rny Date: 01-0z-0z 


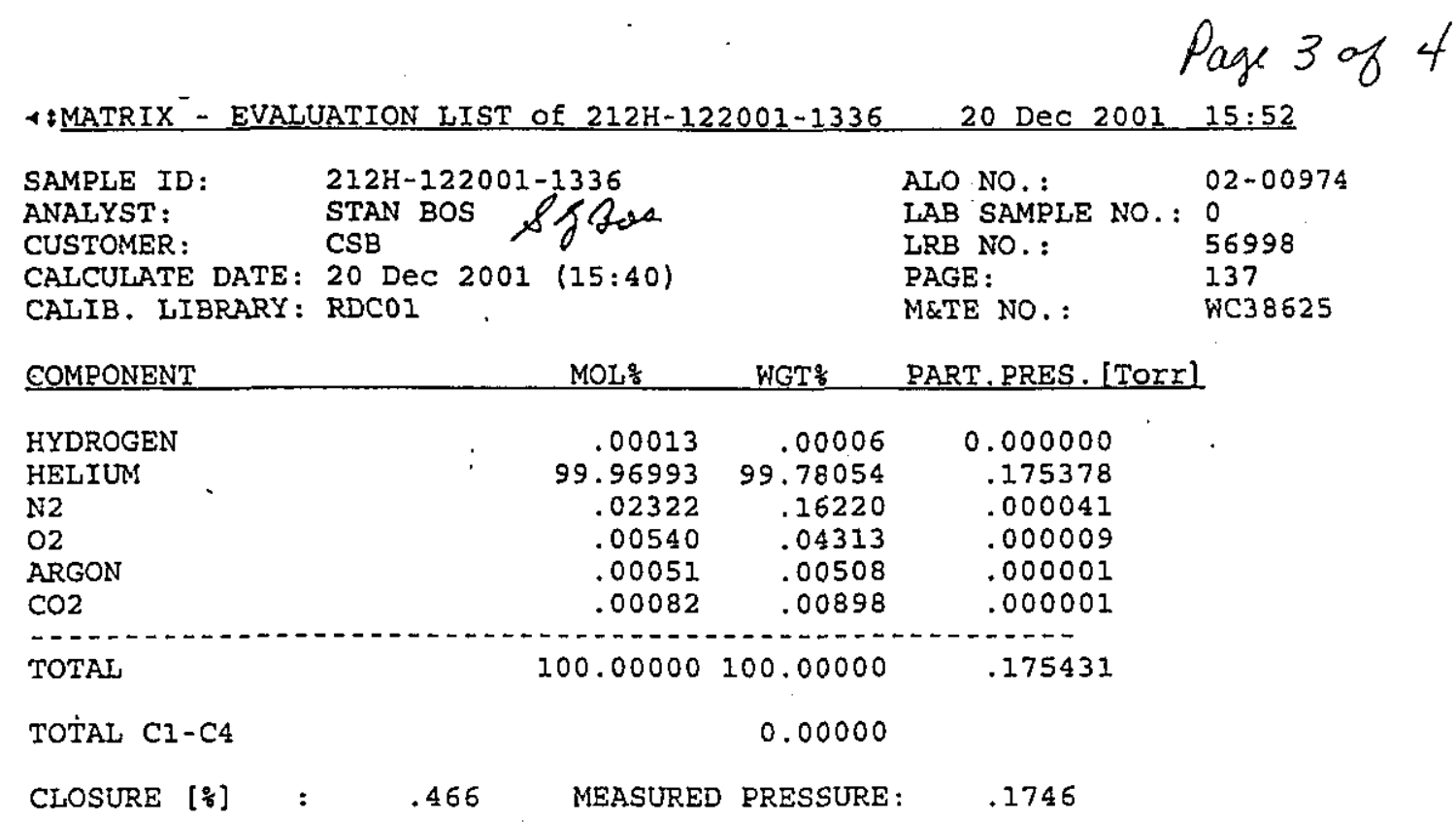

\footnotetext{
Reviewed By: R.KLum Date: 1-2.02
} 
Spent Nuclear Fuel Project Canister Storage Building

Multi-Canister Overpack Sampling System Validation (OCRWM)

SNF-10618

Rev. 0

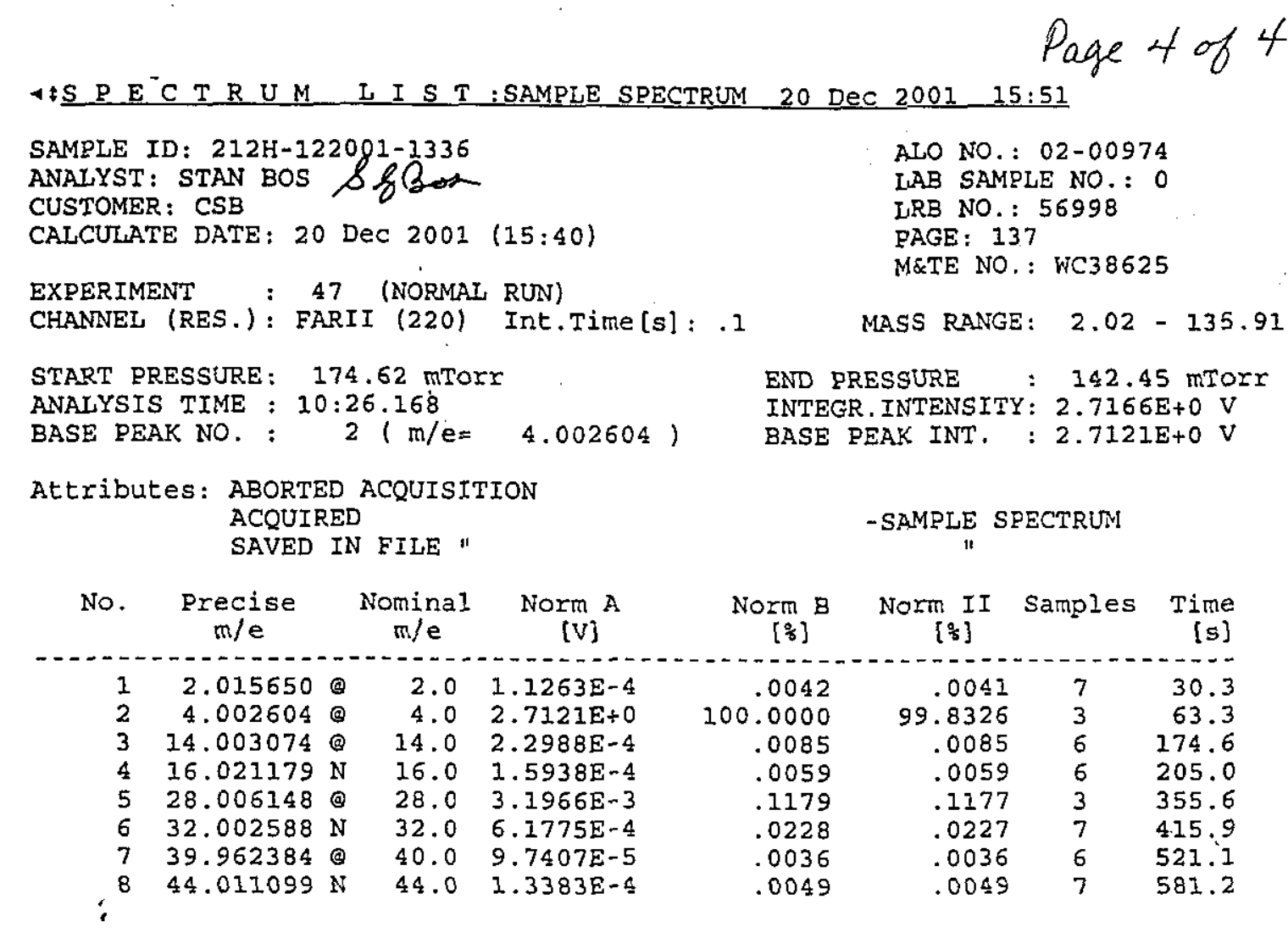

Reviewed By: P.K.B.m Date: $1+z-0 z$ 


\section{Pacific Northwest \\ National Laboratory}

January 11,2002

Frank W. Moore

Fluor Hanford, Inc.

PO Box 1000

Richland, WA 99352

Dear Mr. Moore:

TRANSMITTAL OF REPORT 43469-RPT03, "GAS SPECIES ANALYSIS OF SAMPLES FROM THE CANISTER STORAGE BUILDING RECEIVED BY PNNL ON JANUARY 4, 2002"

Reference: Statement of Work "Analysis of Gas Samples from the Spent Nuclear Fuel (SNF)

Canister Storage (CSB) Facility" transmitted to PNNL on October 26, 2001, accompanying contract 11979-36 (PNNL Project 43469).

Attached please find a copy of report 43469-RPT03, "Gas Species Analysis of Samples from the Canister Storage Building Received by PNNL on January 4, 2002." The samples described in this report were received by PNNL on January 4, 2002, and preliminary results were transmitted on January 4, 2002. The attached report is the final deliverable associated with these samples.

All analyses performed and results reported in the attached document were conducted in compliance with OCRWM standards. This data has been reviewed and determined to be OCRWM-compliant.

Radiochemical Processing Laboratory (RPL) sample identification numbers used in this report were assigned as follows:

\begin{tabular}{|c|c|c|}
\hline RPL Sample ID & Client Sample ID & Client Sample Description \\
\hline $02-01039$ & $212 \mathrm{H}-010402-1048$ & He Gas Sample \\
\hline $02-01040$ & $212 \mathrm{H}-010402-1143$ & MCO Gas Sample \\
\hline
\end{tabular}

If you have any question, please give me a call on $372-4828$.

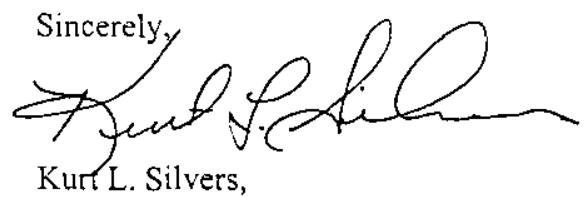

PNNL Project Manager

Attachment

902 Battelle Boulevard • P.O. Box $999 \cdot$ Richland, W'A 99352 
Frank W. Moore

January 11,2002

Page 2

CC: E Biebesheimer, FH (summary only) MS Busch, FH (summary only)

DR Duncan, FH (full data package)

DW Smith, FH (full data package)

GD Bazinet, NHC (summary only)

JP Sloughter, NHC (summary only)

SJ Bos, PNNL (full data package)

AM Lewis, PNNL (summary only)

BM Thornton, PNNL (summary only)

43469 project file 
Gas Species Analysis of Samples from the Canister Storage Building Received by PNNL on January 4, 2002

\section{9-RPT03, Rev. 0}

\section{January 11, 2002}




\section{Gas Species Analysis of Samples from the Canister Storage Building Received by PNNL on January 4, 2002}

43469-RPT03, Rev. 0

Sample Analysis Letter

January 11, 2002

Pacific Northwest National Laboratory 
5. Battelle

... Putting Technology To Work

$\begin{array}{ll}\text { Date } & \text { January 7, } 2002 \\ \text { To } & \text { Kurt Silvers }\end{array}$

From Stan Bos Dtere Bot

Subject Canister Storage Building gas sample analysis
Project No. 43469

Internal Distribution

File/LB

Gas species analyses of samples taken at the Canister Storage Building (CSB) on January 4, 2002 have been completed. A report detailing the gas species detected is attached. Analysis was performed using the Finnigan MAT-271 (WC38625) high sensitivity quantitative mass spectrometer. The sensitivity of the instrument is checked daily prior to use with high purity N2 gas, and two air standards are nun weekly to insure the instrument is operating correctly. The samples were assigned RPL sequence numbers $02-$ 01039 and 02-01040.

Analysis of the evacuated sampler prior to taking the sample was not performed. CSB evacuates the sample cylinders before inletting the sample gas. Since this is a procedural : step, a sampler cleaning analysis becomes unnecessary.

This analysis was performed and the report prepared following PNNL quality assurance plan Nuclear Quality Assurance Requirements and Description (NQARD). NQARD has been evaluated and found to be in conformance with the Office of Civilian Radioactive Waste Management (OCRWM) QA Program. The data in this report is OCRWM QARD Qualified Data.

PNNL project 43469 was setup for document and financial control of the sample analyses. Sample reports and data sheets are stored in the project RDS located in ETB room 2619. Sample analyses are charged to work package F29087.

If you have any questions please contact Stan Bos at 376-5384.

Concurrence P.X.6, 1-9.02 


\section{Gas Species Analysis of} Samples from the Canister Storage Building Received by PNNL on January 4, 2002

\section{9-RPT03, Rev. 0}

- Gas Analysis Summary Results

January 11, 2002

Pacific Northwest National Laboratory 
Spent Nuclear Fuel Project Canister Storage Building

\section{Pacific Northwest National Laboratory}

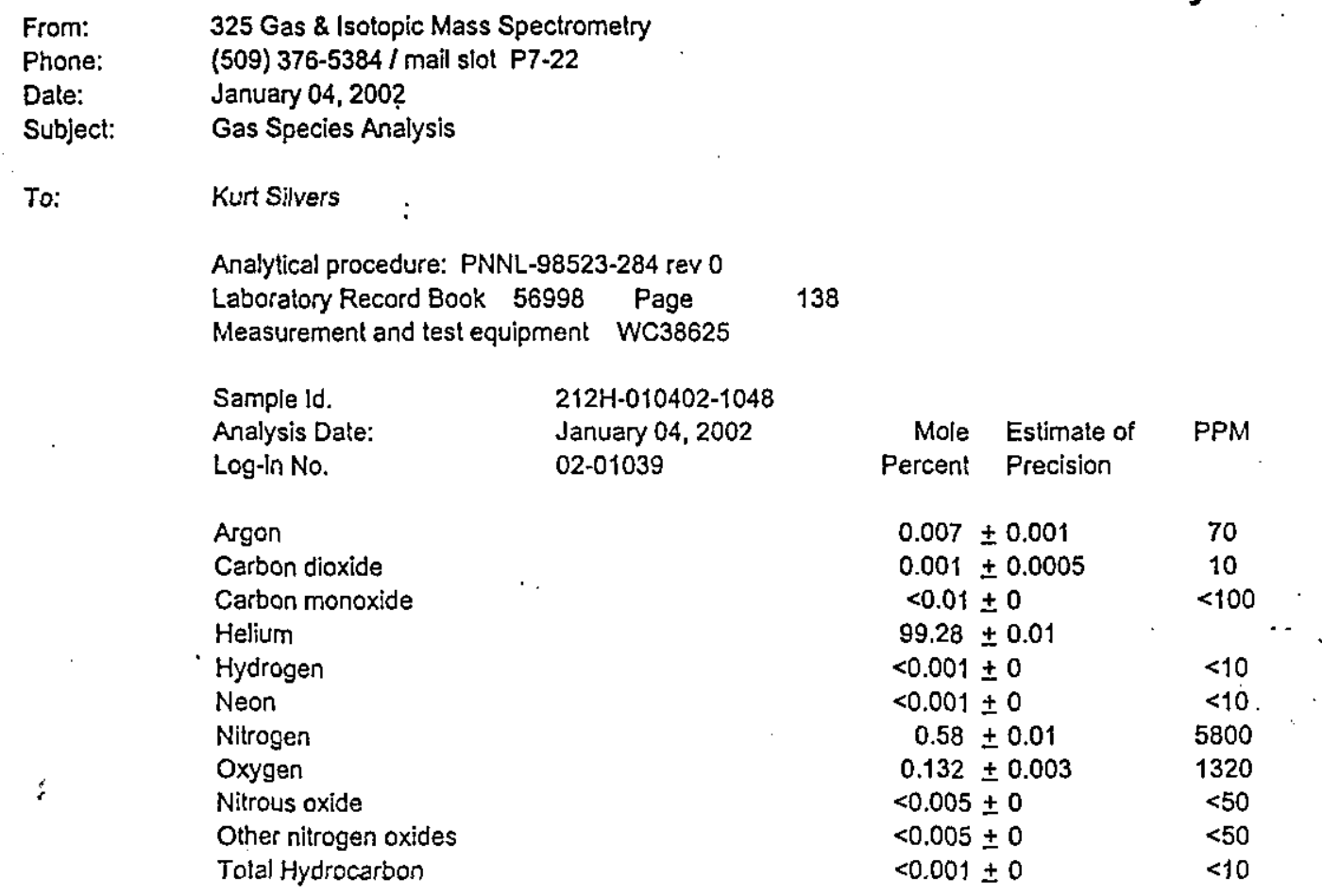

Comments

Water $<100 \mathrm{ppm}$, Sample cylinder valve was loose.

Sample ld.
Analysis Date:
Log-in No.
Argon
Carbon dioxide
Carbon monoxide
Helium
Hydrogen
Neon
Nitrogen
Oxygen
Nitrous oxide
Other nitrogen oxides
Total Hydrocarbon
Comments

Sample Id.

Analysis Date:

Argon

Carbon dioxide

Carbon monoxide

Neon

Nitrous oxide

Other nitrogen oxides

Commenis

212H-010402-1143

January 04,2002

02-01040

$\begin{array}{rlc}\begin{array}{r}\text { Mole } \\ \text { Percent }\end{array} & \text { Estimate of } & \text { Precision } \\ & & \\ 0.024 & \pm 0.001 & 240 \\ 0.002 \pm 0.001 & 20 \\ <0.01 \pm 0 & <100 \\ 97.5 \pm 0.1 & \\ 0.001 \pm 0.0005 & 10 \\ <0.001 \pm 0 & <10 \\ 2 \pm 0.04 & 20000 \\ 0.51 \pm 0.01 & 5100 \\ <0.005 \pm 0 & <50 \\ <0.005 \pm 0 & <50 \\ <0.001 \pm 0 & <10\end{array}$

Water $<1000 \mathrm{ppm}$, Sample cylinder valve was loose. 


\section{Gas Species Analysis of Samples from the Canister Storage Building Received by PNNL on January 4, 2002 \\ 43469-RPT03, Rev. 0}

Chain-of-Custody Form

January 11, 2002

Pacific Northwest National Laboratory 


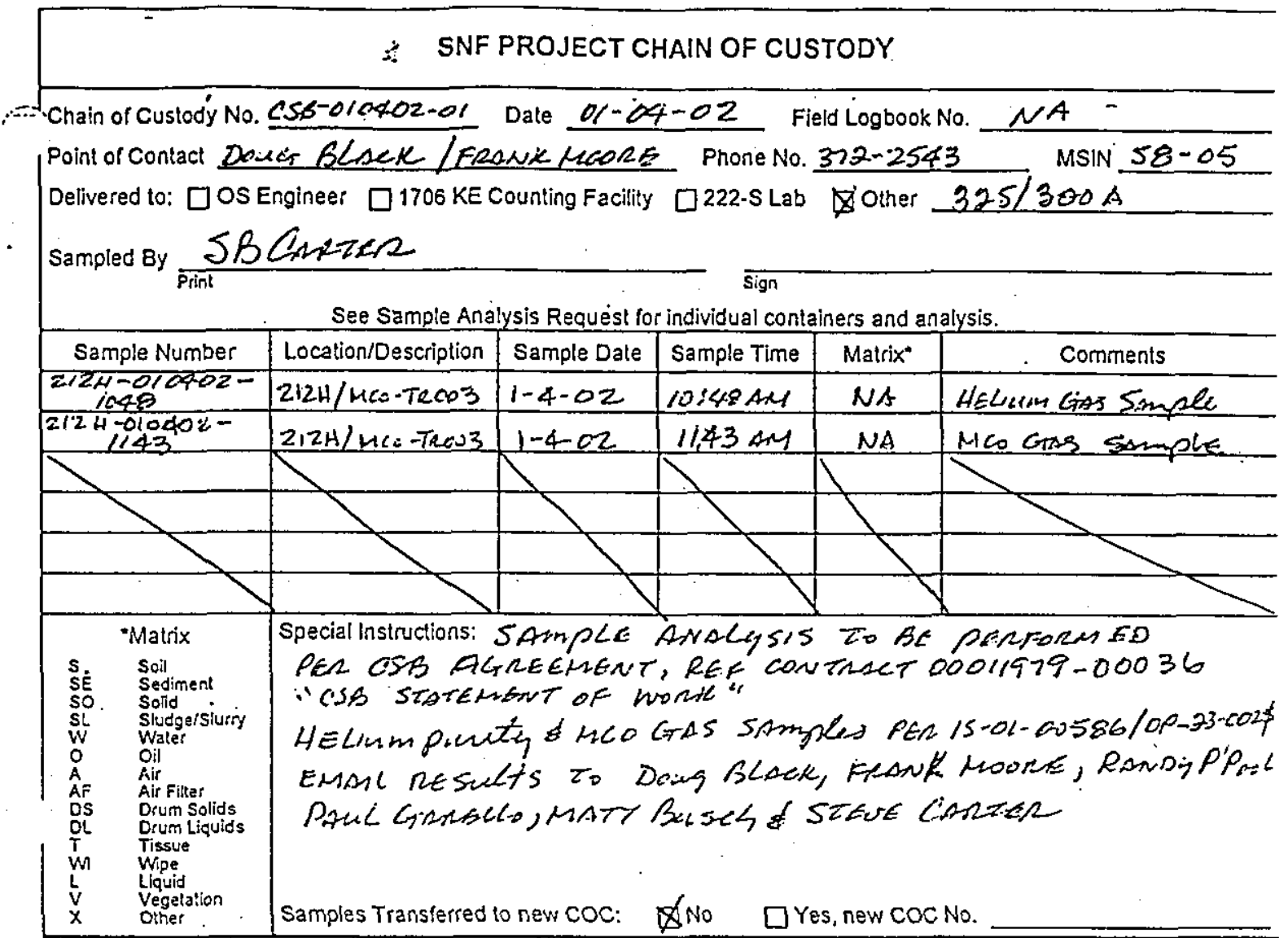

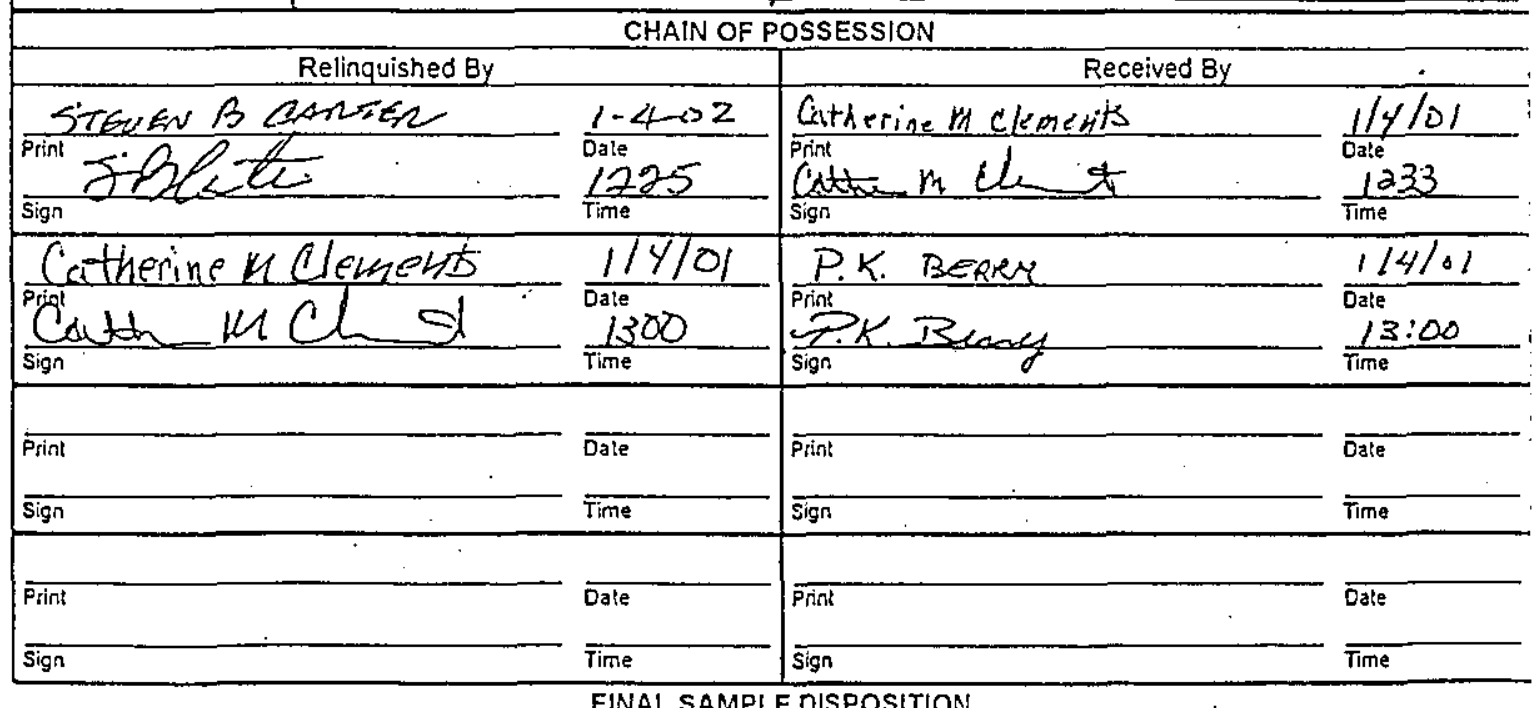

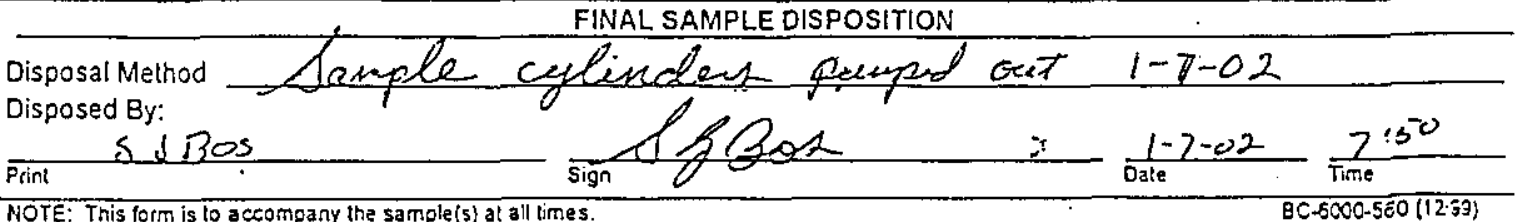




\title{
Gas Species Analysis of Samples from the Canister Storage Building Received by PNNL on January 4, 2002
}

\author{
43469-RPT03, Rev. 0
}

\section{Analytical Services Request}

January 11, 2002

Pacific Northwest National Laboratory 


\section{- Analytical Service Request (ASR)}

(Information on this COVER PAGE is applicable to all samples submitted under this ASR)

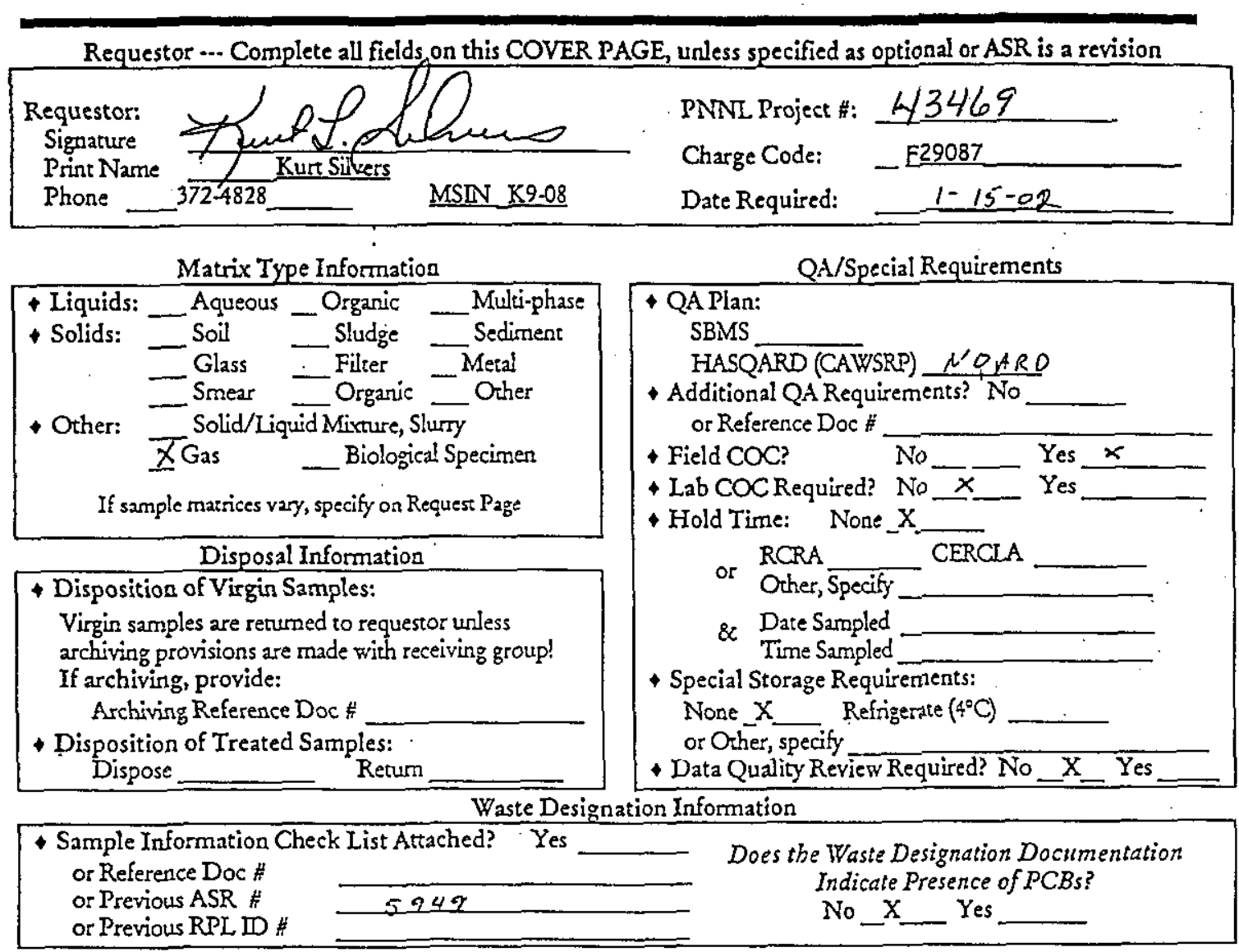

Additional or Special Instructions

Send Report To Kurt. S,luerz Phone $0.372-4828$

Preliminary results requested, as available? No __ Yes ___ (requesting prelimirary results may increase cost)

Receiving and Login Information (to be completed by laboratory staff)

\begin{tabular}{lll}
\hline Date Delivered: & $01-04-02$ \\
Delivered By (optional) & \\
Time Delivered (optional) & \\
Group ID (optional) & & \\
CMC Waste Sample? & No X & \\
Cost Estimate, if requested: $\$$ Y & \\
\hline
\end{tabular}

RPG/CMC Work Accepted By: P.K. BErery

\begin{tabular}{|c|c|}
\hline Received By: & P.R.B. \\
\hline $\begin{array}{l}\text { ASR Number } \\
\text { RPL Numbers: }\end{array}$ & $\begin{array}{l}6321 \\
102-010405-(02-0104 d \\
\text { A2 } 1-1-02\end{array}$ \\
\hline
\end{tabular}

Signature/Date: ASR FY2000 - RPG.doc

$$
\text { Page } 1 \text { of } 2
$$

\section{$1 / 4 / 02$}




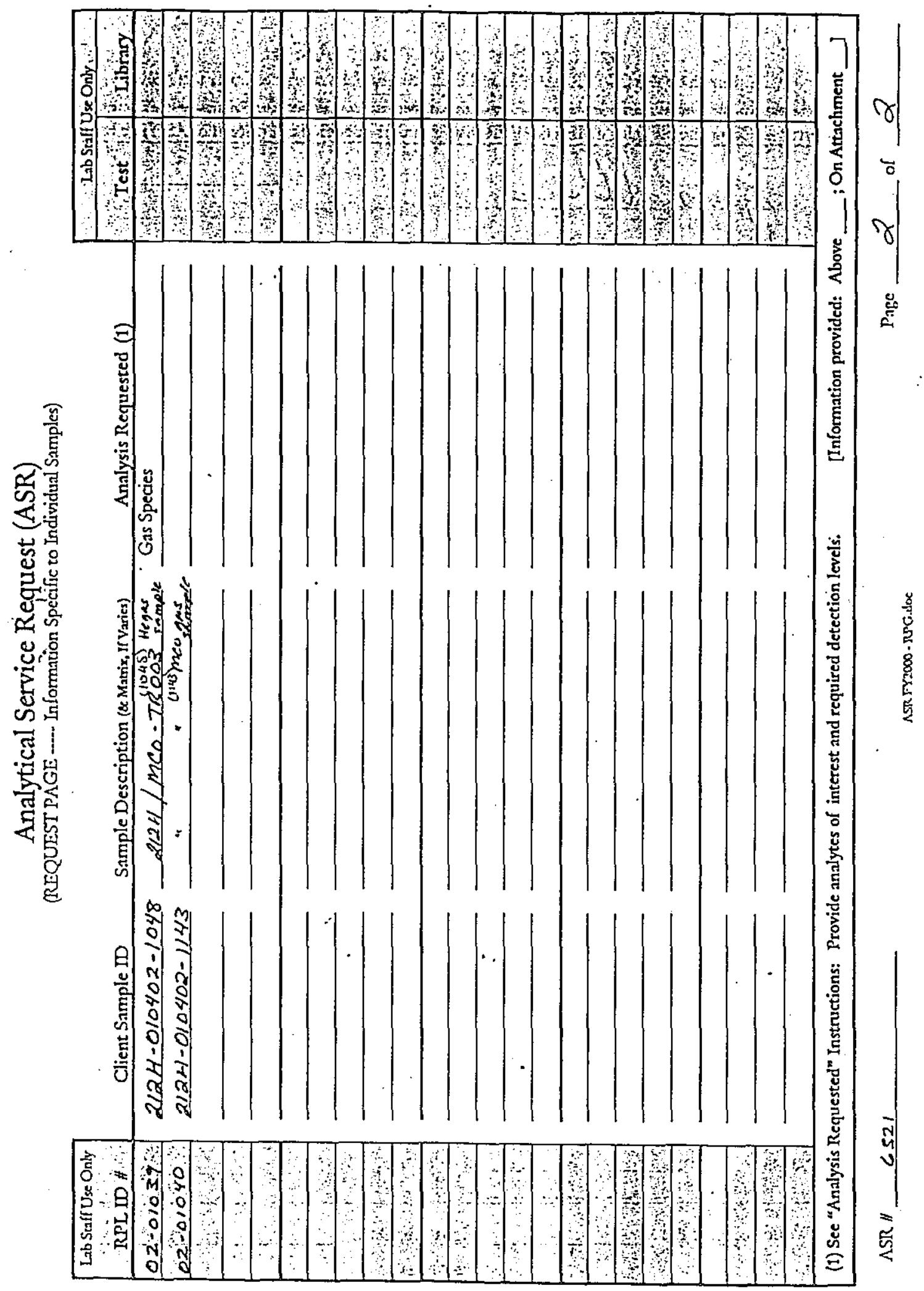


Gas Species Analysis of Samples from the Canister Storage Building Received by PNNL on January 4, 2002

43469-RPT03, Rev. 0

\section{Quality Control Check}

January 11, 2002

Pacific Northwest National Laboratory 


\section{Pacific Northwest National Laboratory}

From: 325 Gas \& Isotopic Mass Spectrometry

Phone: (509) 376-3358 / mail slot P7-22

Date: January 02, 2002

Subject: Air standards from Finnigan MAT - 271 Mass Spectromeler

Analytical procedure: PNNL - 98523 - 284 Rev. 0

Laboratory Record Book 56998: Page 137

Measurement and test equipment WC38625

Accepted values for the composition of air :

$\begin{array}{lc} & \text { Mole percent } \\ \text { Argon } & 0.934 \\ \text { Nitrogen } & 78.08 \\ \text { Oxygen } & 20.95\end{array}$

Analyzed Values:

Analysis Date: $\quad$ January 02,2002

Argon

Nitrogen

Mole percent

Oxygen

0.94

78.16

20.86

Analyzed Values:

\begin{tabular}{|c|c|}
\hline Analysis Date: & January 02,2002 \\
\hline & Mole percent \\
\hline Argon & 0.937 \\
\hline Nitrogen & 77.94 \\
\hline Oxygen & 21.08 \\
\hline
\end{tabular}

- Instrument Background:

Background analyses are run daily prior to sample analyses. Trace amounts of hydrogen andlor water in the 0.1 to 0.2 millivolt range were the only species detected. The background spectra is subtracted from each sample spectra. 


\section{Gas Species Analysis of Samples from the Canister Storage Building Received by PNNL on January 4, 2002} 43469-RPT03, Rev. 0

Raw Instrument Data from Gas Analysis

\section{January 11, 2002}

Pacific Northwest National Laboratory 
Spent Nuclear Fuel Project Canister Storage Building

Multi-Canister Overpack Sampling System Validation (OCRWM)

SNF-10618

Rev. 0

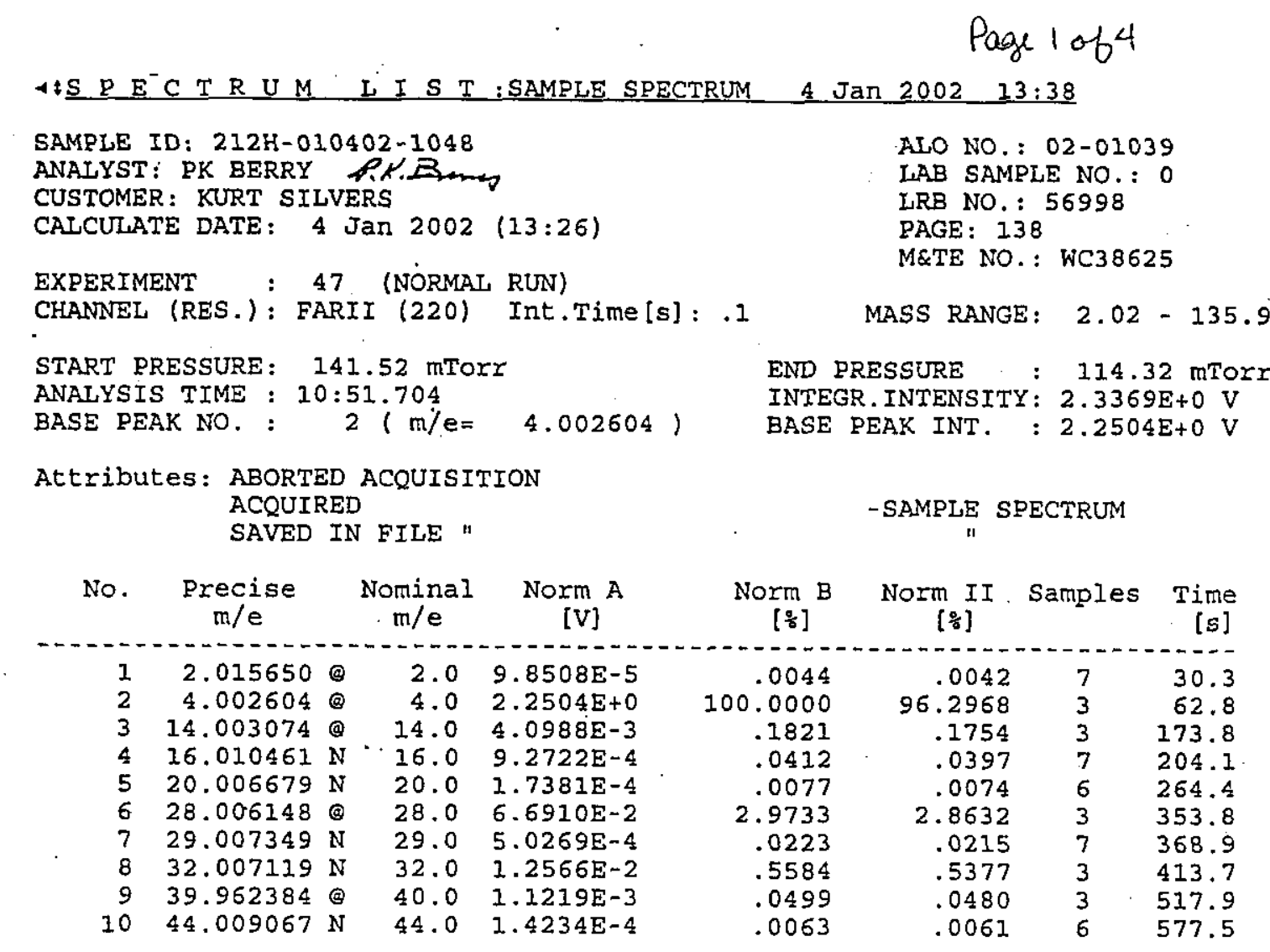

Reviewed By:

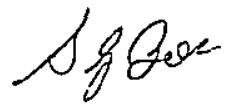

Date: $1 / 4 / 02$ 
Spent Nuclear Fuel Project Canister Storage Building

SNF-10618

Multi-Canister Overpack Sampling System Validation (OCRWM)

Rev. 0

\begin{tabular}{|c|c|c|c|c|}
\hline \multirow{2}{*}{\multicolumn{3}{|c|}{ MATRIX - EVALUATION LIST of 212H-010402-1048 }} & \multicolumn{2}{|r|}{ Page 2} \\
\hline & & & $4 \operatorname{Jan} 2002$ & $13: 39$ \\
\hline $\begin{array}{l}\text { SAMPLE ID: } \\
\text { ANALYST: } \\
\text { CUSTOMER: } \\
\text { CALCULATE DATE: } \\
\text { CALIB. IIBRARY: }\end{array}$ & $\begin{array}{l}212 \mathrm{H}-010402-1048 \\
\text { RK BERRY P.K.B.m } \\
\text { KURT SILVERS } \\
4 \text { Jan } 2002(13: 26) \\
\text { RDCO1. }\end{array}$ & & $\begin{array}{l}\text { ALO NO.: } \\
\text { LAB SAMPLE NO.: } \\
\text { LRB NO.: } \\
\text { PAGE: } \\
\text { M\&TE NO.: }\end{array}$ & $\begin{array}{l}02-01039 \\
0 \\
56998 \\
138 \\
\text { WC38625 }\end{array}$ \\
\hline COMPONENT & MOL $\%$ & WGT: & \multicolumn{2}{|l|}{ PART , PRES [Torf] } \\
\hline $\begin{array}{l}\text { HELIUM } \\
\text { N2 } \\
\text { O2 } \\
\text { ARGON } \\
\text { CO2 }\end{array}$ & $\begin{array}{r}99.27926 \\
.58119 \\
.13150 \\
.00702 \\
.00103\end{array}$ & $\begin{array}{r}95.02128 \\
3.89383 \\
1.00689 \\
.06717 \\
.01083\end{array}$ & $\begin{array}{l}.140473 \\
.000822 \\
.000186 \\
.000010 \\
.000001\end{array}$ & \\
\hline $\begin{array}{ll}\text { TOTAL } \\
\text { TOL }\end{array}$ & 100.00000 & 100.00000 & .141493 & \\
\hline TOTAL CI-C4 & & 0.00000 & & \\
\hline CLOSURE [\%] & MEASURED & PRESSURE: & .1415 & \\
\hline $\mathrm{cy}$ & $\begin{array}{c}\text { nola volve was not } \\
.:\end{array}$ & Tiskt & encisty $h$ & \\
\hline Reviewed By: & g Bear & $1 / 4 / 0$ & 2 & \\
\hline
\end{tabular}




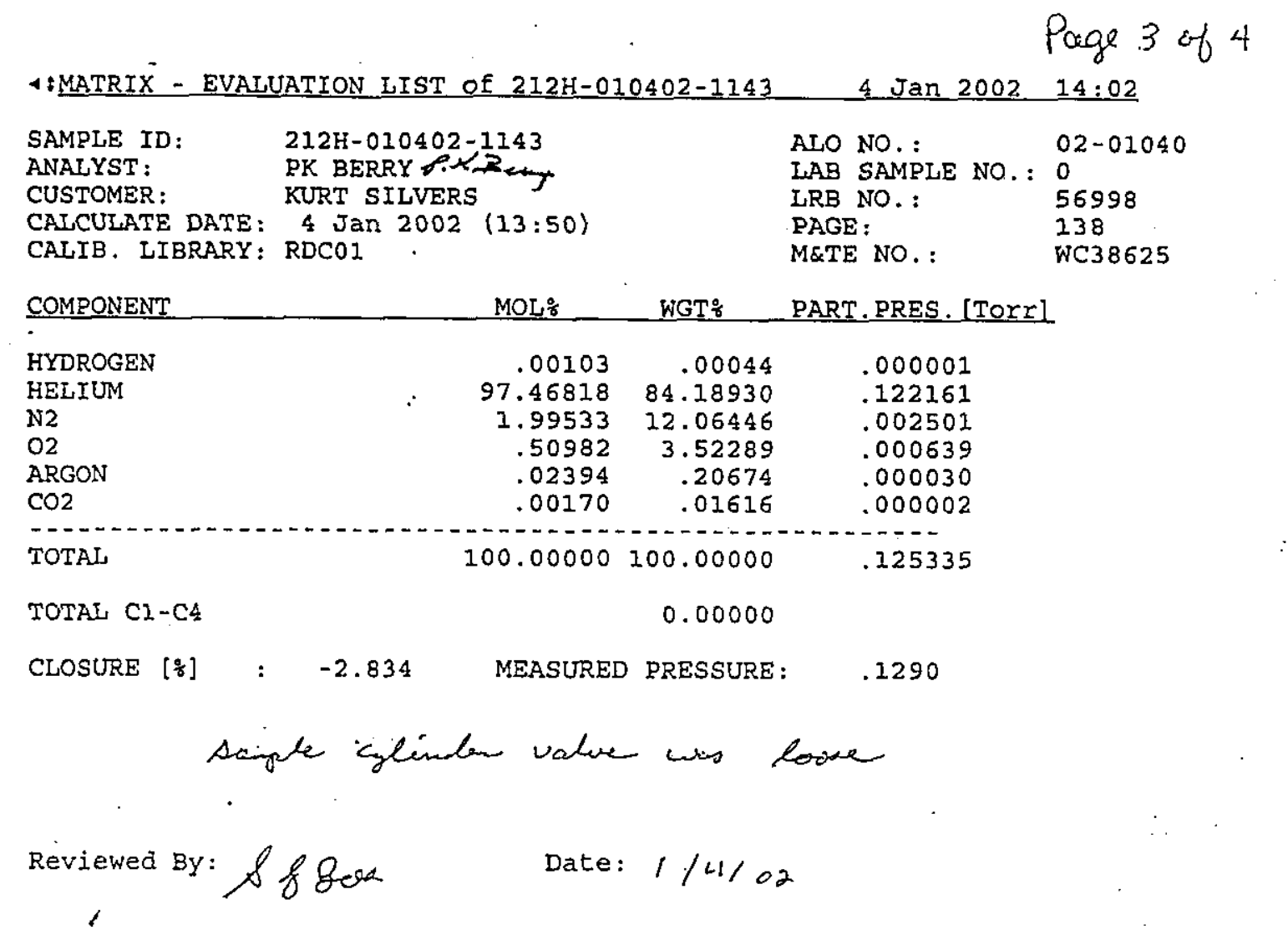




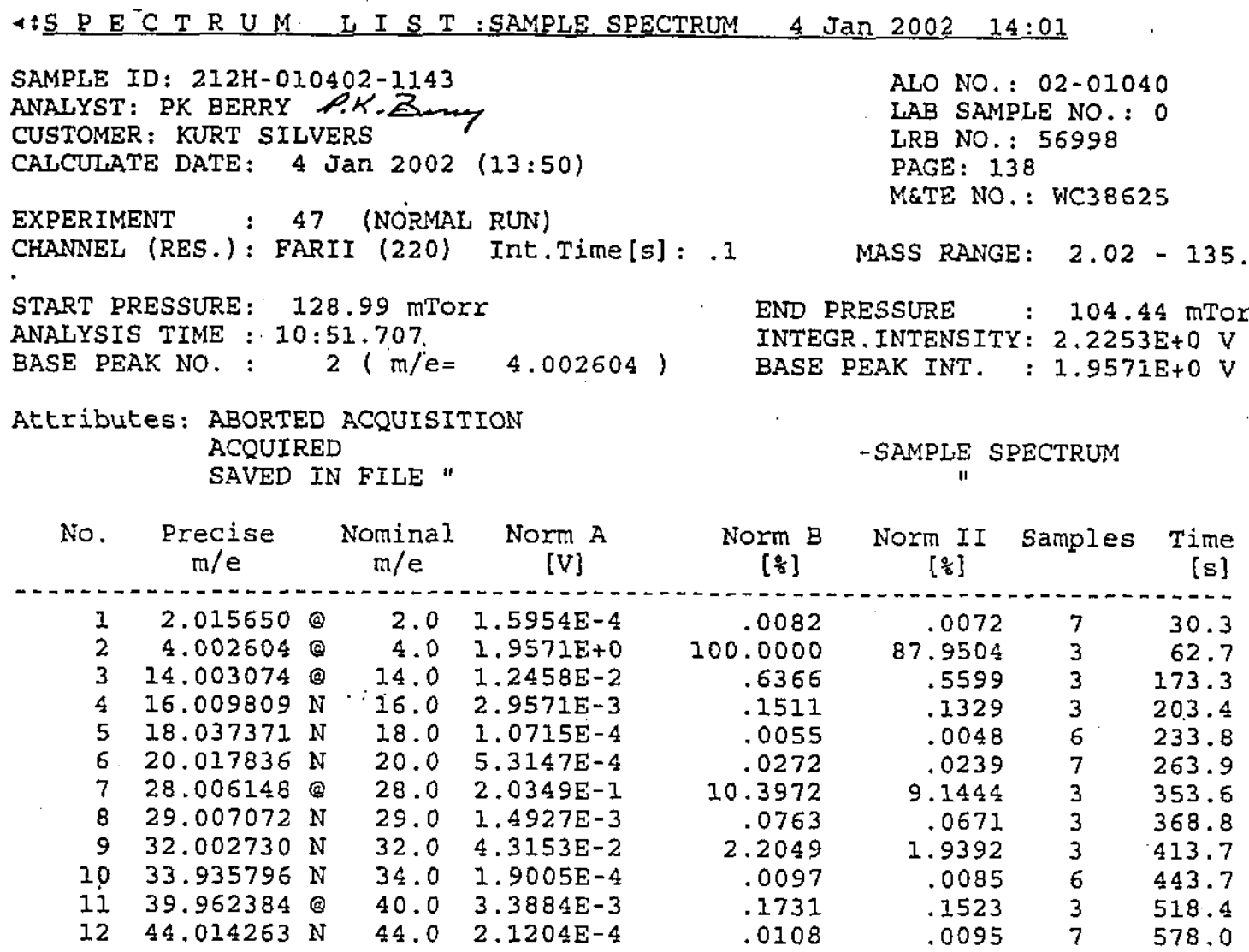

Reviewed By:

Date:

$1 / 4102$ 


\section{Pacific Northwest National Laboratory}

January 11,2002

Frank W. Moore

Fluor Hanford, Inc.

PO Box 1000

Richland, WA 99352

Dear Mr. Moore:

TRANSMITTAL OF REPORT 43469-RPT04, "GAS SPECIES ANALYSIS OF SAMPLES FROM THE CANISTER STORAGE BUILDING RECEIVED BY PNNL ON JANUARY 8, 2002"

Reference: Statement of Work "Analysis of Gas Samples from the Spent Nuclear Fuel (SNF)

Canister Storage (CSB) Facility" transmitted to PNNL on October 26, 2001, accompanying contract 11979-36 (PNNL Project 43469).

Attached please find a copy of report 43469-RPT04, "Gas Species Analysis of Samples from the Canister Storage Building Received by PNNL on January 8, 2002." The samples described in this report were received by PNNL on January 8, 2002. The preliminary results were transmitted on January 8, 2002; however, due to a typographical error related to the precision of the helium measurement, the preliminary results were reissued on January 9,2002. The attached report is the final deliverable associated with these samples.

All analyses performed and results reported in the attached document were conducted in compliance with OCRWM standards. This data has been reviewed and determined to be OCRWM-compliant.

Radiochemical Processing Laboratory (RPL) sample identification numbers used in this report were assigned as follows:

\begin{tabular}{|c|c|c|}
\hline RPL Sample ID & Client Sample ID & Client Sample Description \\
\hline $02-01045$ & $212 \mathrm{H}-010702-2209$ & He Gas Sample \\
\hline $02-01046$ & $212 \mathrm{H}-010702-2235$ & MCO Gas Sample \\
\hline
\end{tabular}

If you have any question, please give me a call on $372-4828$.

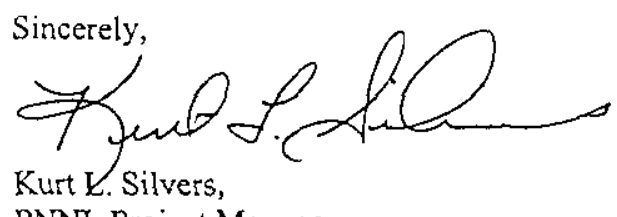

PNNL Project Manager

Attachment 
Frank W. Moore

January 11, 2002

Page 2

CC: E Biebesheimer, FH (summary only) MS Busch, FH (summary only)

DR Duncan, FH (full data package)

DW Smith, FH (full data package)

GD Bazinet, NHC (summary only)

JP Sloughter, NHC (summary only)

SJ Bos, PNNL (full data package)

AM Lewis, PNNL (summary only)

BM Thornton, PNNL. (summary only)

43469 project file 
Gas Species Analysis of Samples from the Canister Storage Building Received by PNNL on January 8, 2002

43469-RPT04, Rev. 0

January 11, 2002

\section{Pacific Northwest National Laboratory}


Gas Species Analysis of Samples from the Canister Storage Building Received by PNNL on January 8, 2002

43469-RPT04, Rev. 0

Sample Analysis Letter

January 11, 2002

Pacific Northwest National Laboratory 


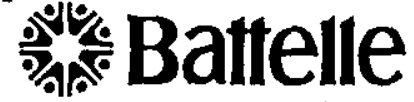

... Putting Technology To Work

Date January 9,2002

To $\quad$ Kurt Silvers

From stan Bos Jtane Boos

Subject Canister Storage Building gas sample analysis
Project No. $\underline{43469}$

Internal Distribution

File/LB

Gas species analyses of samples taken at the Canister Storage Building (CSB) on January 7,2002 have been completed. A report detailing the gas species detected is attached. Analysis was performed using the Finnigan MAT-271 (WC38625) high sensitivity quantitative mass spectrometer. The sensitivity of the instrument is checked daily prior to use with high purity $\mathrm{N} 2$ gas, and two air standards are run weekly to insure the instrument is operating correctly. The samples were assigned RPL sequence numbers 0201046 and $02-01046$. 01045 .

Analysis of the evacuated sampler prior to taking the sample was not performed. CSB evacuates the sample cylinders before inletting the sample gas. Since this is a procedural ; step, a sampler cleaning analysis becomes unnecessary.

This analysis was performed and the report prepared following PNNL quality assurance plan Nuclear Quality Assurance Requirements and Description (NQARD). NQARD has been evaluated and found to be in conformance with the Office of Civilian Radioactive Waste Management (OCRWM) QA Program. The data in this report is OCRWM QARD Qualified Data.

PNNL project 43469 was setup for document and financial control of the sample analyses. Sample reports and data sheets are stored in the project RIDS located in ETB room 2619. Sample analyses are charged to work package F29087.

If you have any questions pleaśe contact Stan Bos at 376-5384.

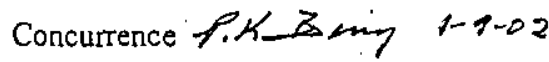




\section{Gas Species Analysis of} Samples from the Canister Storage Building Received by PNNL on January 8, 2002

\section{9-RPT04, Rev. 0}

- Gas Analysis Summary Results

January 11, 2002

Pacific Northwest National Laboratory

4 


\section{Pacific Northwest National Laboratory}

$\begin{array}{ll}\text { From: } & 325 \text { Gas \& Isotopic Ma } \\ \text { Phone: } & \text { (509) } 376-5384 \text { / mail } \\ \text { Date: } & \text { January 08, 2002 } \\ \text { Subject: } & \text { Gas Species Analysis } \\ \text { To: } & \text { Kurt Slvers } \\ & \text { Analytical procedure: } \\ & \text { Laboratory Record Book } \\ & \text { Measurement and test } \\ & \text { Sample ld. } \\ & \text { Analysis Date: } \\ & \text { Log-in No. } \\ & \text { Argon } \\ & \text { Carbon dioxide } \\ & \text { Carbon monoxide } \\ & \text { Helium } \\ & \text { Hydrogen } \\ & \text { Neon } \\ & \text { Nitrogen } \\ & \text { Oxygen } \\ & \text { Nitrous oxide } \\ & \text { Other nitrogen oxides } \\ & \text { Total Hydrocarbon } \\ & \end{array}$

Comments

Sample Id.

Analysis Date:

Log-in No.

Argon

Carbon dioxide

Carbon monoxide

Helium

Hydrogen

Neon

Nitrogen

Oxygen

Nitrous oxide

Other nitrogen oxides

Total Hydrocarbon

Comments
$212 \mathrm{H}-010702-2209$

January 08, 2002

02-01045

Water was not delected

212H-010702-2235

January 08, 2002

02-01046

$\begin{array}{rlc}\begin{array}{r}\text { Mole } \\ \text { Percent }\end{array} & \text { Estimate of } & \text { Precision } \\ & \\ 0.024 \pm 0.001 & 240 \\ 0.003 \pm 0.001 & 30 \\ <0.01 \pm 0 & <100 \\ 97.5 \pm 0.1 & \\ <0.001 \pm 0 & <10 \\ <0.001 \pm 0 & <10 \\ 1.99 \pm 0.04 & 19900 \\ 0.49 \pm 0.01 & 4900 \\ <0.005 \pm 0 & <50 \\ <0.005 \pm 0 & <50 \\ <0.001 \pm 0 & <10\end{array}$

Water was not detected

$\begin{array}{cc}\begin{array}{r}\text { Mole } \\ \text { Percent }\end{array} \text { Prtimate of } & \text { PPM } \\ & \\ <0.001 \pm 0 & <10 \\ 0.002 \pm 0.001 & 20 \\ <0.01 \pm 0 & <100 \\ 99.98 \pm 0.01 & \\ <0.001 \pm 0 & <10 \\ <0.001 \pm 0 & <10 \\ 0.018 \pm 0.001 & 180 \\ 0.002 \pm 0.001 & 20 \\ <0.005 \pm 0 & <50 \\ <0.005 \pm 0 & <50 \\ <0.001 \pm 0 & <10\end{array}$

138

$<10$

$<10$
180

20

$<50$

$<10$ 


\section{Gas Species Analysis of Samples from the Canister Storage Building Received by PNNL on January 8, 2002}

43469-RPT04, Rev. 0

\section{Chain-of-Custody Form}

January 11, 2002

Pacific Northwest National Laboratory 


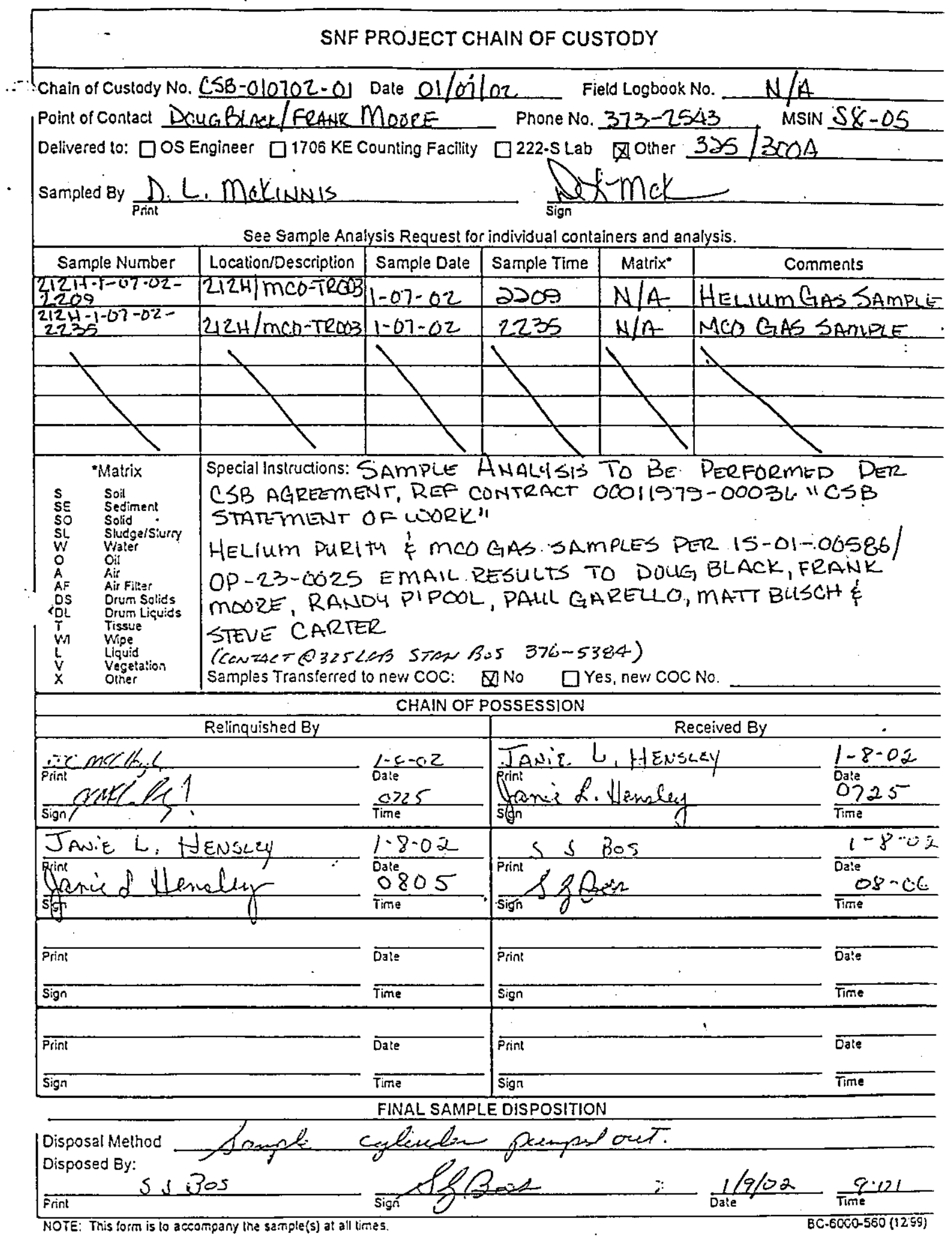




\title{
Gas Species Analysis of
} Samples from the Canister Storage Building Received by PNNL on January 8, 2002

\author{
43469-RPT04, Rev. 0
}

\section{Analytical Services Request}

January 11, 2002

Pacific Northwest National Laboratory 
(Information on this COVER PAGE is applicable to all samples subritted under this ASR)

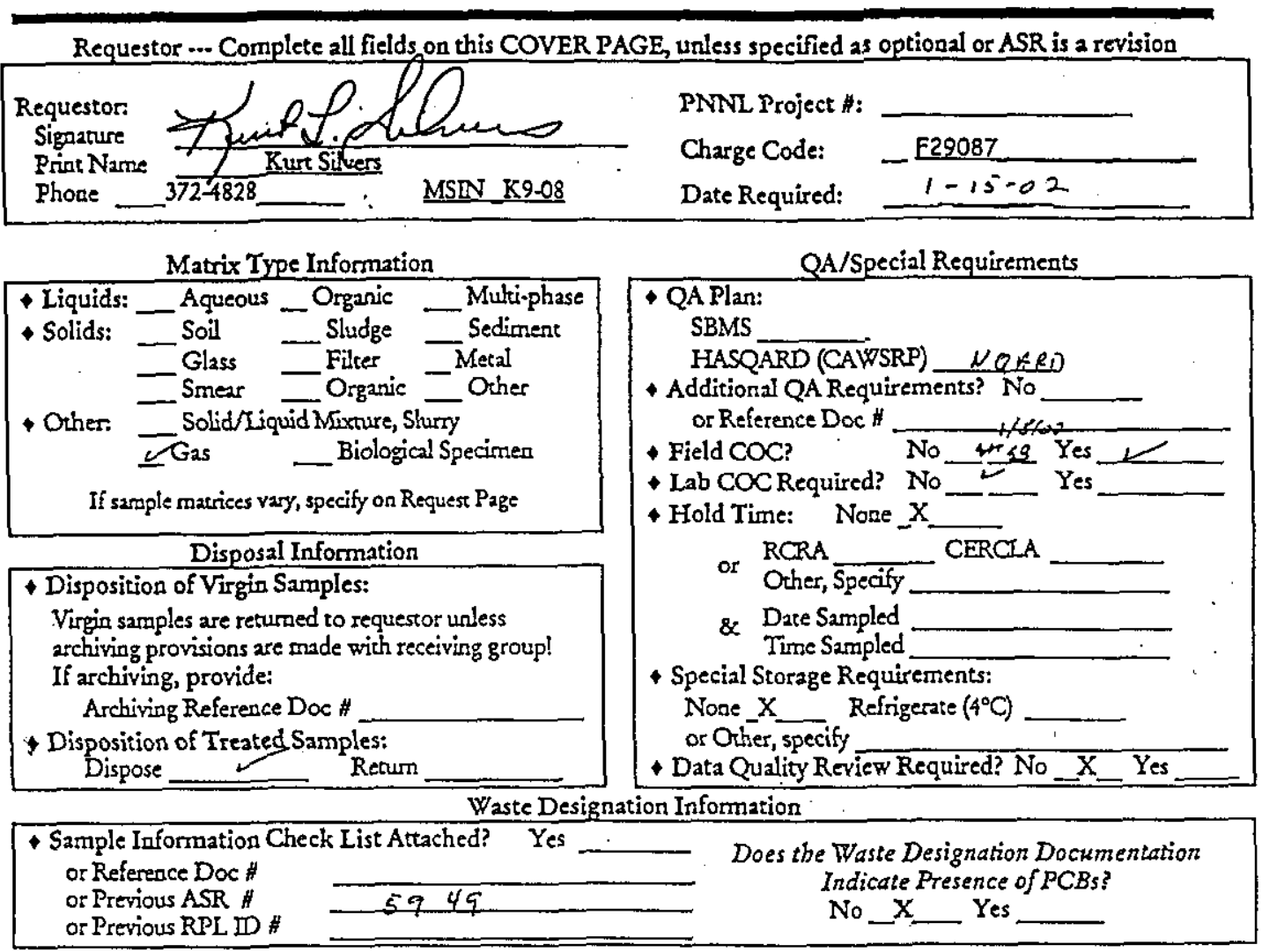

Additional or Special Kenstructions

Send Report To

\section{Receiving and Login Information (to be completed by laboratory staff)}

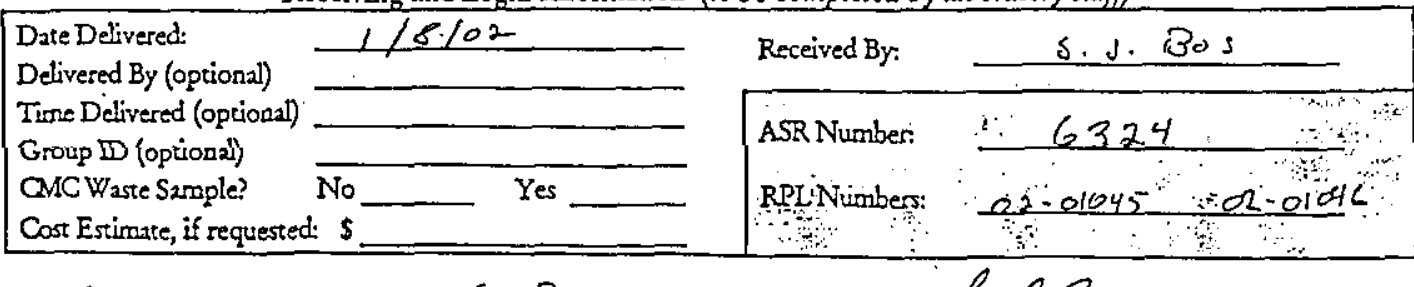

RPG/CMC WorkAccepted By: SSBOS Signature/Date: NSR FY2000 - RPG doc 
Spent Nuclear Fuel Project Canister Storage Building

SNF-10618

Multi-Canister Overpack Sampling System Validation (OCRWM)

Rev. 0

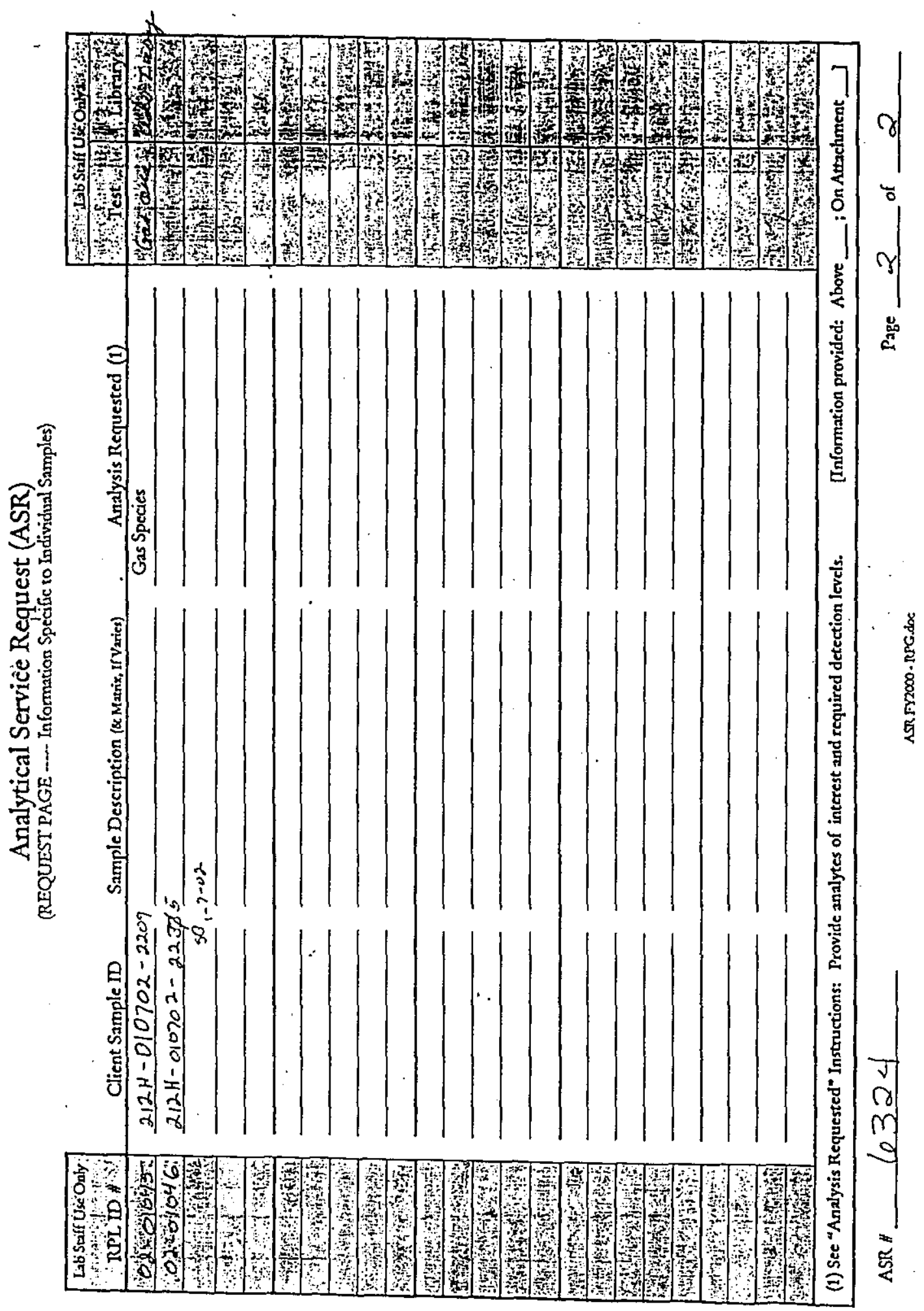




\section{Gas Species Analysis of Samples from the Canister Storage Building Received by PNNL on January 8, 2002}

43469-RPT04, Rev. 0

Quality Control Check

January 11, 2002

Pacific Northwest National Laboratory 
Spent Nuclear Fuel Project Canister Storage Building Multi-Canister Overpack Sampling System Validation (OCRWM)

SNF-10618

Rev. 0

\section{Pacific Northwest National Laboratory}

From: 325 Gas \& Isotopic Mass Spectrometry

Phone: (509) 376-3358 / mail slot P7-22

Date: January 07, 2002

Subject: Air standards from Finnigan MAT - 271 Mass Spectrometer

Analytical procedure: PNNL - 98523 - 284 Rev. 0

Laboratory Record Book 56998: Page 138

Measurement and test equipment WC38625

Accepted values for the composition of air :

$\begin{array}{lc} & \text { Mole percent } \\ \text { Argon } & 0.934 \\ \text { Nitrogen } & 78.08 \\ \text { Oxygen } & 20.95\end{array}$

Analyzed Values:

Analysis Date: January 07,2002

i

$\begin{array}{lc} & \text { Mole percent } \\ \text { Argon } & 0.938 \\ \text { Nitrogen } & 78.05 \\ \text { Oxygen } & 20.97\end{array}$

Analyzed Values:

Analysis Date: January 07,2002

$\begin{array}{lc} & \text { Mole percent } \\ \text { Argon } & 0.937 \\ \text { Nitrogen } & 77.92 \\ \text { Oxygen } & 21.11\end{array}$

Instrument Background:

Background analyses are run daily prior to sample analyses. Trace amounts of hydrogen and/or water in the 0.1 to 0.2 millivolt range were the only species detected. The background spectra is subtracted from each sample spectra. 


\section{Gas Species Analysis of Samples from the Canister Storage Building Received by PNNL on January 8, 2002 43469-RPT04, Rev. 0 \\ Raw Instrument Data from Gas Analysis}

January 11, 2002

Pacific Northwest National Laboratory 
Spent Nuclear Fuel Project Canister Storage Building Multi-Canister Overpack Sampling System Validation (OCRWM)

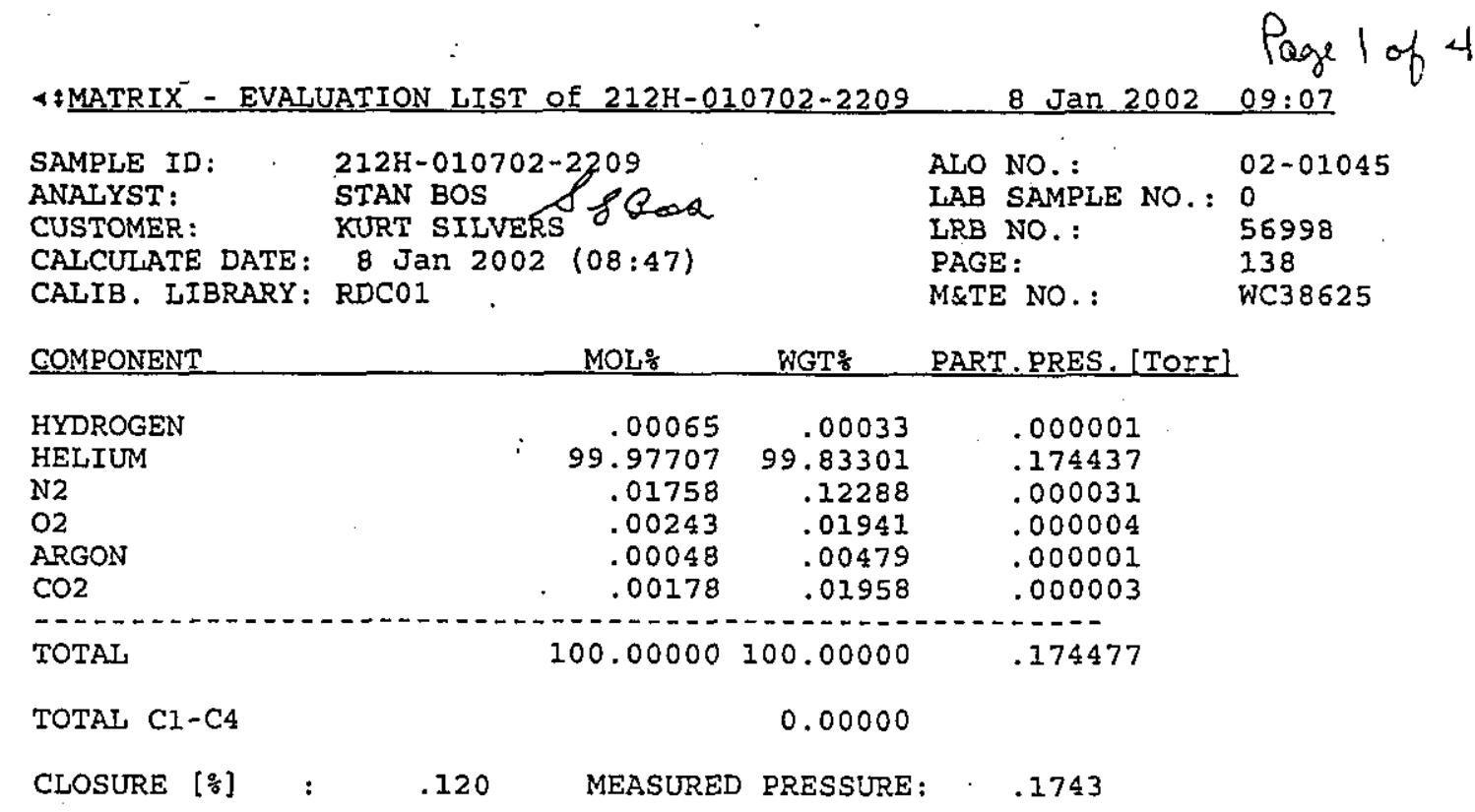

Réviewed By: थ C

Date: 1- $\&-02$ 


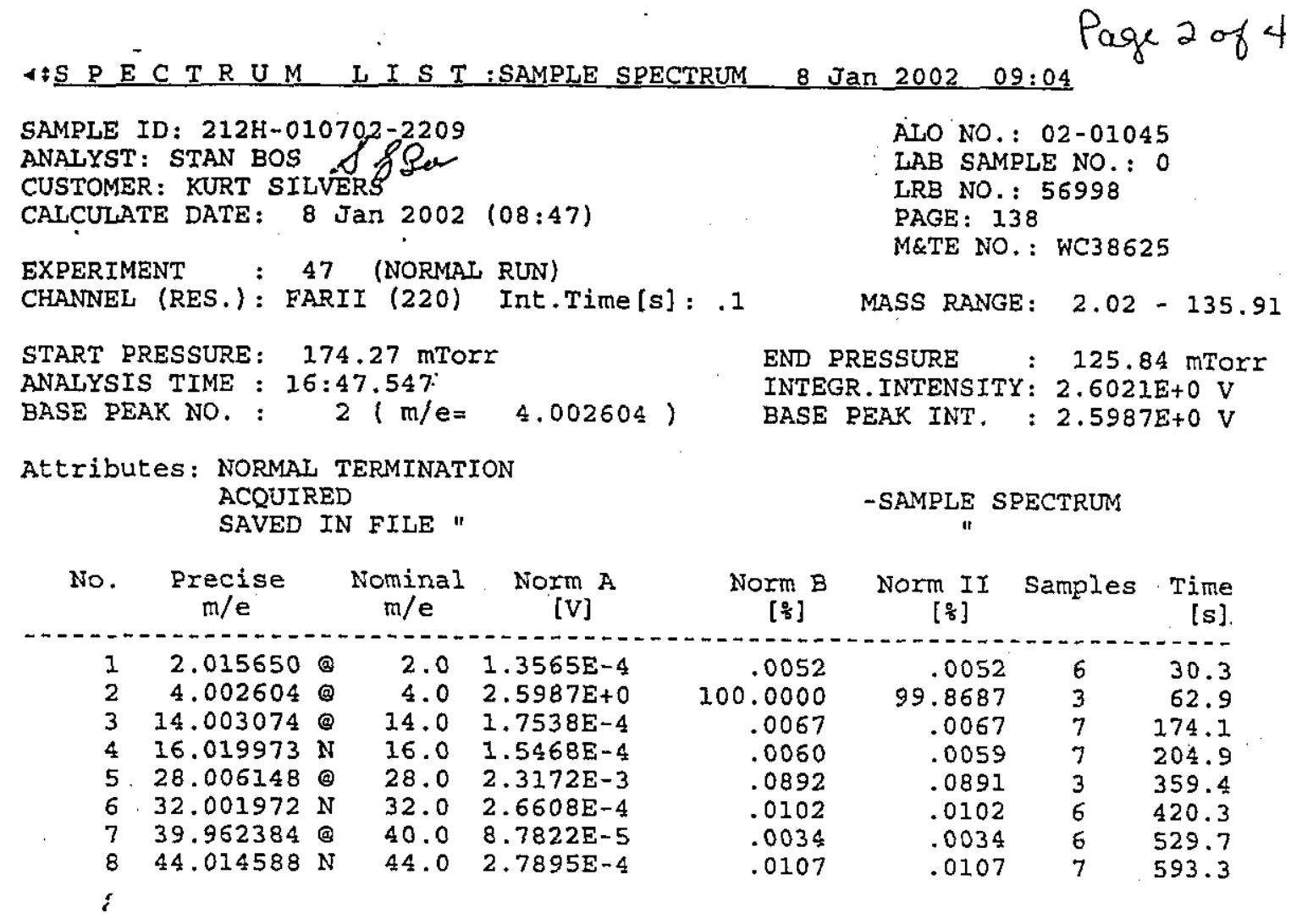

Reviewed BY: P./. B.m. Date: $1-9.02$ 
Spent Nuclear Fuel Project Canister Storage Building Multi-Canister Overpack Sampling System Validation (OCRWM)

SNF-10618

Rev. 0

Page 3 of 4

4 MATRI $\bar{X}$ - EVALUATION LIST of 212H-010702-2235_ـ 8 Jan 2002 10:30

$\begin{array}{llll}\text { SAMPLE ID: } & 212 \mathrm{H}-010702-2235 & \text { ALO NO.: } & 02-01046 \\ \text { ANALYST: } & \text { STAN BOS } & \text { LAB SAMPLE NO.: } & 0 \\ \text { CUSTOMER: } & \text { KURT SILVERS } & \text { LRB NO.: } & 56998 \\ \text { CALCULATE DATE: } & 8 \text { JaI 2002 }(09: 22) & \text { PAGE: } & 138 \\ \text { CALIB. LIBRARY: } & \text { RDCO1 . } & \text { METE NO.: } & \text { WC38625 }\end{array}$

COMPONENT MOL\% WGT _ W PART.PRES. [TOIT]

\begin{tabular}{lrrr} 
HYDROGEN & .00082 & .00035 & .000001 \\
HELIUM & 97.49274 & 84.32744 & .157773 \\
N2 & 1.99010 & 12.04951 & .003221 \\
O2 & .48926 & 3.38550 & .000792 \\
ARGON & .02367 & .20473 & .000038 \\
CO2 & .00341 & .03245 & .000006 \\
\hdashline TOTAL & 100.00000 & 100.00000 & .161831
\end{tabular}

$\begin{array}{ll}\text { TOTAL } \mathrm{Cl}-\mathrm{C4} & 0.00000\end{array}$

CLOSURE [\%] : .786 MEASURED PRESSURE: .1606

Reviewed By: $2 \mu \quad$ Date: $1-\infty-<_{2}$ 


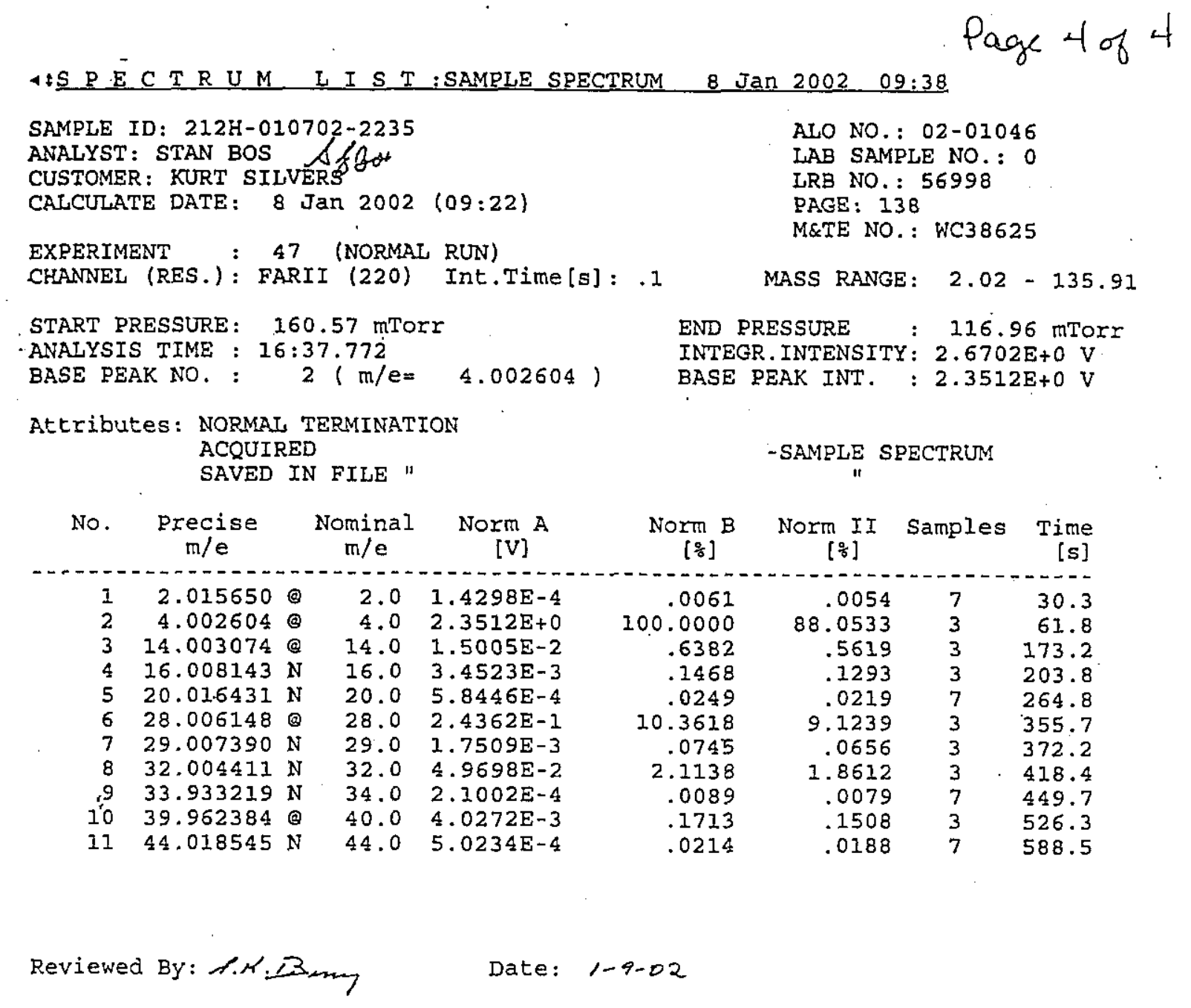




\section{Pacific Northwest National Laboratory

January 17,2002

Frank W. Moore

Fluor Hanford, Inc.

PO Box 1000

Richland, WA 99352

Dear Mr. Moore:

TRANSMITTAL OF REPORT 43469-RPT05, "GAS SPECIES ANALYSIS OF SAMPLES FROM THE CANISTER STORAGE BUILDING RECEIVED BY PNNL ON JANUARY 10, 2002"

Reference: $\quad$ Statement of Work "Analysis of Gas Samples from the Spent Nuclear Fuel (SNF) Canister Storage (CSB) Facility" transmitted to PNNL on October 26, 2001, accompanying contract 11979-36 (PNNL Project 43469).

Attached please find a copy of report 43469-RPT05, "Gas Species Analysis of Samples from the Canister Storage Building Received by PNNL on January 10, 2002." The samples described in this report were received by PNNL on January 10, 2002 in two batches; the preliminary results for samples 02-01249 and 02-01250 were transmitted on January 10,2002 and the preliminary results for sample 02-01253 were transmitted on January 11,2002 . The attached report is the final deliverable associated with these samples.

All analyses performed and results reported in the attached document were conducted in compliance with OCRWM standards. This data has been reviewed and determined to be OCRWM-compliant.

Radiochemical Processing Laboratory (RPL) sample identification numbers used in this report were assigned as follows:

\begin{tabular}{|c|c|c|}
\hline RPL Sample ID & Client Sample ID & Client Sample Description \\
\hline $02-01249$ & $212 \mathrm{H}-010902-2144$ & He Gas Sample \\
\hline $02-01250$ & $212 \mathrm{H}-010902-2232$ & MCO Gas Sample \\
\hline $02-01253$ & $212 \mathrm{H}-011002-1517$ & MCO Gas Sample \\
\hline
\end{tabular}

If you have any question, please give me a call on $372-4828$.

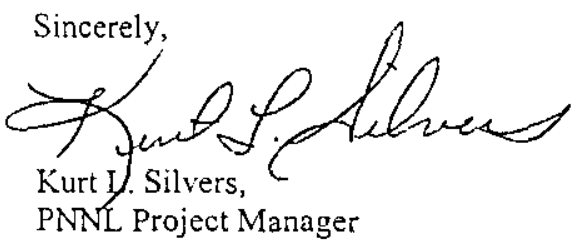

Attachment

902 Battelle Boulevard • P.O. Box $999 \cdot$ Riclıland, NA 99352 
Spent Nuclear Fuel Project Canister Storage Building

SNF-10618

Multi-Canister Overpack Sampling System Validation (OCRWM)

Rev. 0

Frank W. Moore

January 17, 2002

Page 2

CC: E Biebesheimer, FH (summary only) MS Busch, FH (summary only)

DR Duncan, FH (full data package)

DW Smith, FH (full data package)

GD Bazinet, NHC (summary only)

JP Sloughter, NHC (summary only)

SI Bos, PNNL (full data package)

AM Lewis, PNNL (summary only)

BM Thornton, PNNL (summary only)

43469 project file 
Gas Species Analysis of Samples from the Canister Storage Building Received by PNNL on January 10, 2002

43469-RPT05, Rev. 0

January 17, 2002

Pacific Northwest National Laboratory 
Gas Species Analysis of Samples from the Canister Storage Building Received by PNNL on January 10, 2002

43469-RPT05, Rev. 0

Sample Analysis Letter

January 17, 2002

Pacific Northwest National Laboratory 


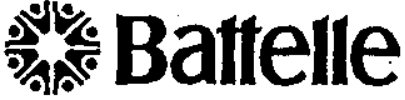

... Putting Technology To Work

Date January 14,2002

To Kurt Silvers

From stan Bos Jtan 200

subject Canister Storage Building gas sample analysis
Projoct Na. $\underline{43469}$

Inlemal Distribution

File/LB

Gas species analyses of samples taken at the Canister Storage Building (CSB) on January 10 and 11, 2002 have been completed. A report detailing the gas species detected is attached. Analysis was performed using the Finnigan MAT-271 (WC38625) high sensitivity quantitative mass spectrometer. The sensitivity of the instrument is checked daily prior to use with high purity N2 gas, and two air standards are run weekly to insure the instrument is operating correctly. The samples were assigned RPL sequence numbers 02-01249, 02-01250 and 02-01253.

Analysis of the evacuated sampler prior to taking the sample was not performed. CSB evacuates the sample cylinders before inletting the sample gas. Since this is a procedural step, a sampler cleaning analysis becomes unnecessary.

This analysis was performed and the report prepared following PNNL quality assurance plan Nuclear Quality Assurance Requirements and Description (NQARD). NQARD has been evaluated and found to be in conformance with the Office of Civilian Radioactive Waste Management (OCRWM) QA. Program. The data in this report is OCRWM QARD Qualified Data.

PNNL project 43469 was setup for document and financial control of the sample analyses. Sample reports and data sheets are stored in the project RDS located in ETB room 2619. Sample analyses are charged to work package F29087.

If you have any questions please contact Stan Bos at 376-5384.

Concurrence P.M.B. 


\title{
Gas Species Analysis of
} Samples from the Canister Storage Building Received by PNNL on January 10, 2002

$$
\text { 43469-RPT05, Rev. } 0
$$

Gas Analysis Summary Results

\author{
January 17, 2002
}

\section{Pacific Northwest National Laboratory}




\section{Pacific Northwest National Laboratory}

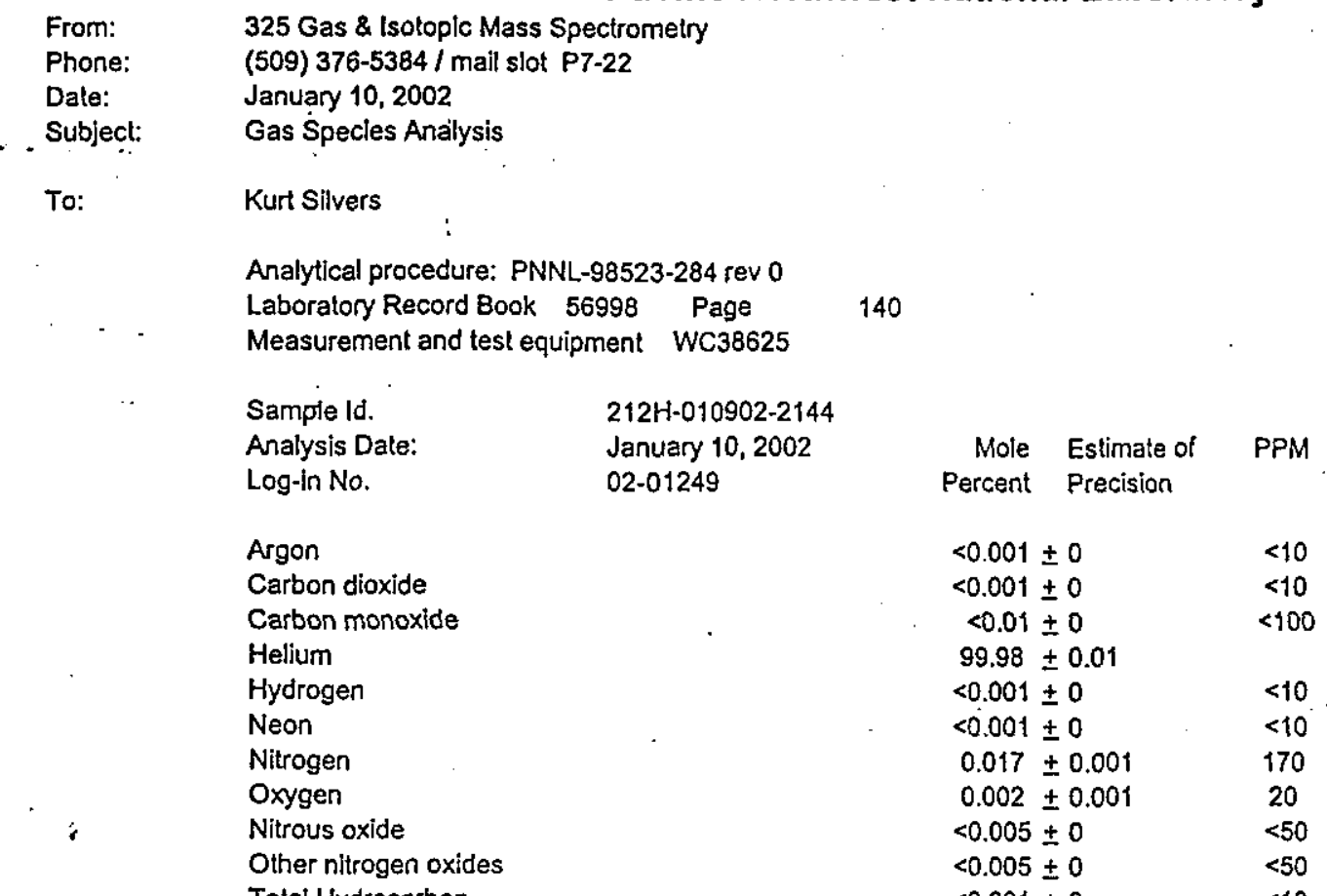

Total Hydrocarbon

Water was not detecled

Sample Id.

Analysis Date:

Log-in No.

Argon

Carbon dioxide

Carbon monoxide

Helium

Hydrogen

Neon

Nitrogen

Oxygen

Nitrous oxide

Other nitrogen oxides

Total Hydrocarbon

Comments
$212 \mathrm{H}-010902-2232$

January 10,2002

02-01250

$\begin{array}{rc}\begin{array}{r}\text { Mole } \\ \text { Percent }\end{array} \text { Prtimate of } & \text { PPM } \\ & \\ 0.023 \pm 0.001 & \\ 0.002 \pm 0.001 & 230 \\ <0.01 \pm 0 & 20 \\ 97.5 \pm 0.1 & <100 \\ <0.001 \pm 0 & \\ <0.001 \pm 0 & <10 \\ 1.95 \pm 0.04 & <10 \\ 0.48 \pm 0.01 & 19500 \\ <0.005 \pm 0 & 4800 \\ <0.005 \pm 0 & <50 \\ <0.001 \pm 0 & <50 \\ <0 & <10\end{array}$


Spent Nuclear Fuel Project Canister Storage Building

SNF-10618

Multi-Canister Overpack Sampling System Validation (OCRWM)

Rev. 0

Pacific Northwest National Laboratory

From: $\quad 325$ Gas \& 1solopic Mass Spectrometry

Phone: $\quad$ (509) $376.5384 /$ mail slot P7.22

Date: January 11, 2002

- Subject: Gas Species Aralysis

To: $\quad$ Kurt Silvers

Analytical procedure: PNNL-98523-284 rev 0

Laboratory Record Book $56998 \quad$ Page

140

Measurement and test equipment WC38625

Sample id.

212H-011002-1517

Analysis Date:

January 11,2002

Log-in No.

02-01253

$\begin{aligned} \text { Mole Estimate of PPM } & \\ \text { Percent Precision } & \end{aligned}$

Argon

Carbon dioxide

Carbon monoxide

Helium

Hydrogen

Neon

Nitrogen

Oxygen

Nitrous oxide

Other nitrogen oxides

Total Hydrocarbon

$0.027 \pm 0.001$

270

$0.002 \pm 0.001$

$<0.01 \pm 0$

$97.1 \pm 0.1$

$<0.001 \pm 0$

$<0.001 \pm 0$

$2.28 \pm 0.05$

$0.57 \pm 0.01$

$<0.005 \pm 0$

$<0.005 \pm 0$

$<0.001 \pm 0$

Water was not delected 
Gas Species Analysis of Samples from the Canister Storage Building Received by PNNL on January 10, 2002

43469-RPT05, Rev. 0

Chain-of-Custody Forms

January 17, 2002

Pacific Northwest National Laboratory 


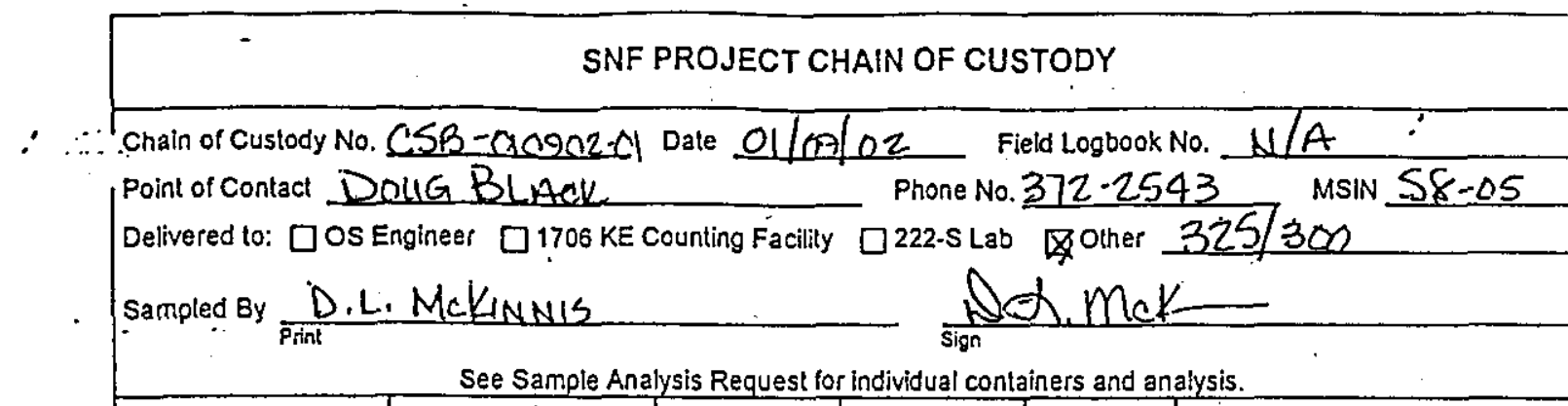

\begin{tabular}{|c|c|c|c|c|c|}
\hline Sample Number & Localion/Description & Sample Date & Sample Time & Matrix* & Commenis \\
\hline 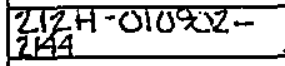 & 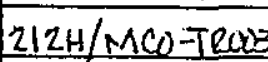 & $01 / 09 / 0 z$ & 2144 & $N / A$ & HELIUM GAS SAMPIC \\
\hline $212+1-201002-2232$ & ZIZH/MCO-TROOB & $109 / 02$ & 2232 & $N / A$ & mencescsima. \\
\hline & & & & & \\
\hline & & & & & \\
\hline & \multirow{2}{*}{\multicolumn{5}{|c|}{ 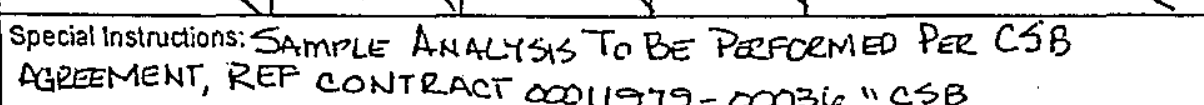 }} \\
\hline 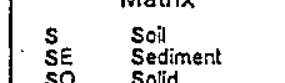 & & & & & \\
\hline 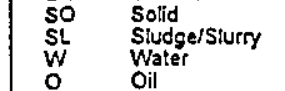 & \multicolumn{5}{|c|}{ STATEMENT OF WORK" } \\
\hline 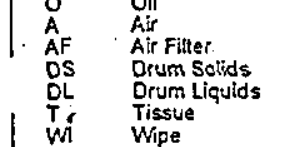 & \multicolumn{5}{|c|}{ EMALL RESULTS To } \\
\hline 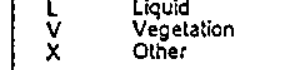 & & & & & \\
\hline
\end{tabular}

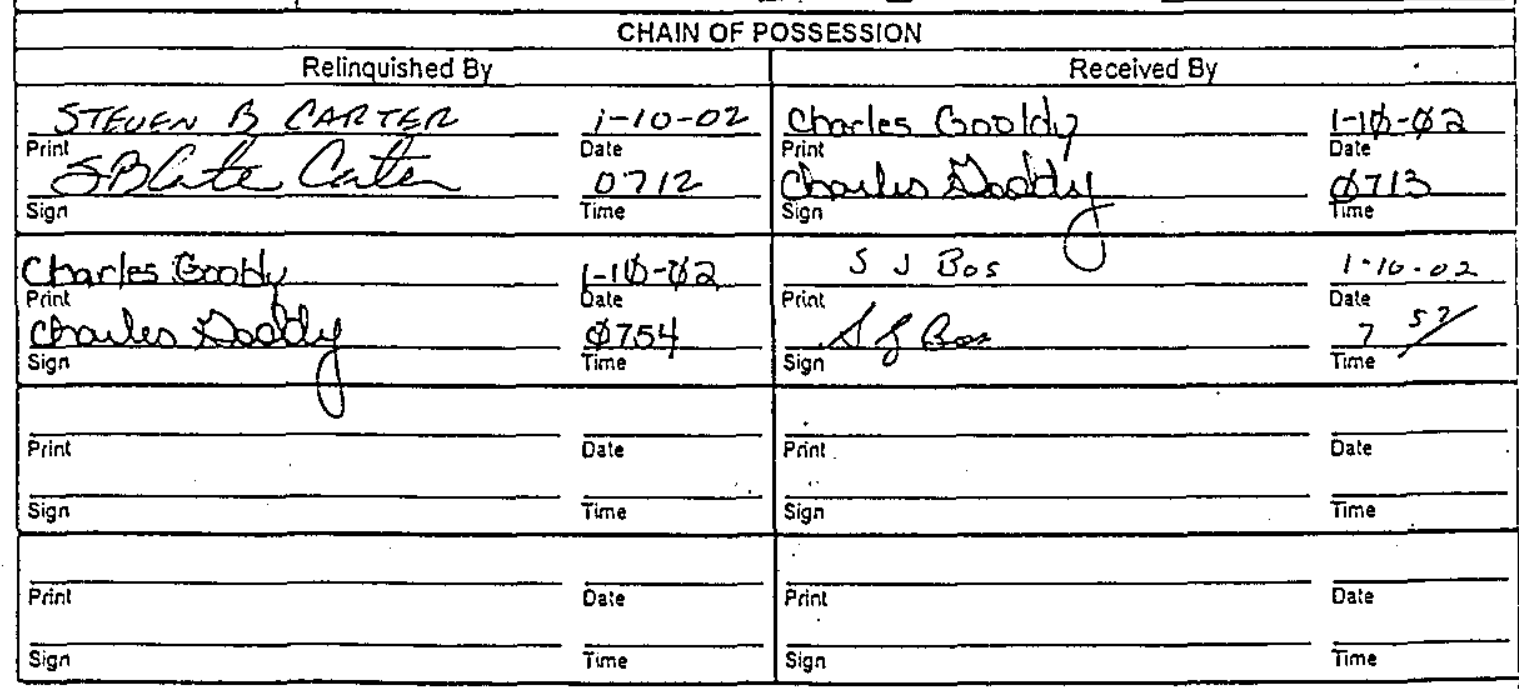

FINAL SAMPLE DISPOSITION

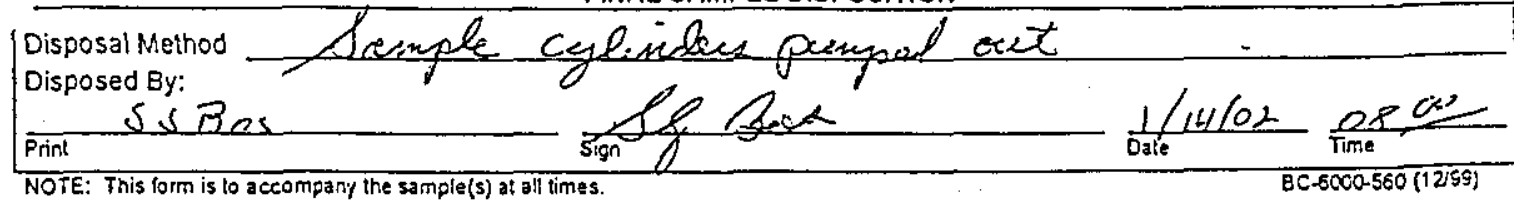


Spent Nuclear Fuel Project Canister Storage Building

SNF-10618

Multi-Canister Overpack Sampling System Validation (OCRWM)

Rev. 0

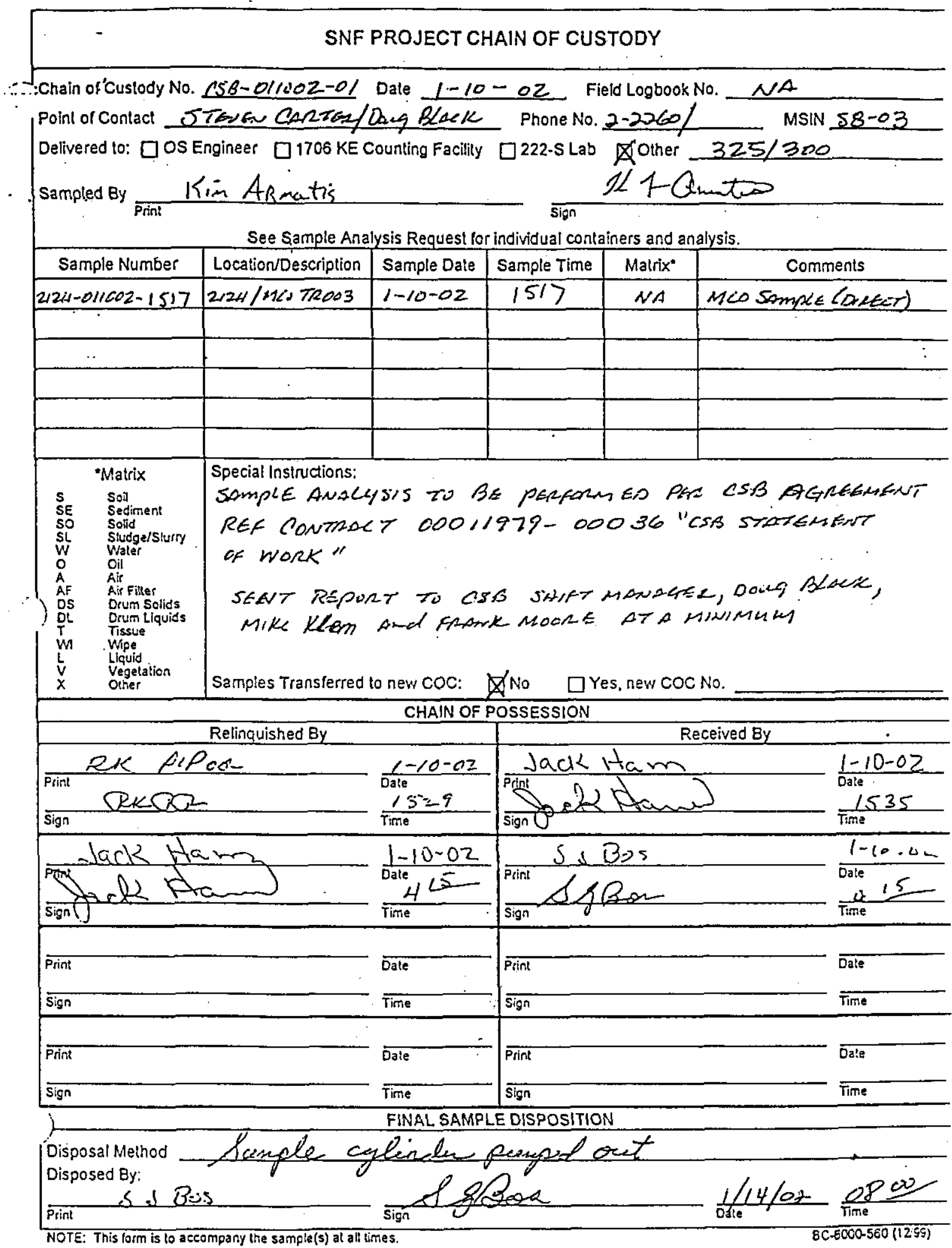


Gas Species Analysis of Samples from the Canister Storage Building Received by PNNL on January 10, 2002

43469-RPT05, Rev. 0

\section{Analytical Services Request}

January 17, 2002

Pacific Northwest National Laboratory 
Analytical Service Request (ASR)

(Information on this COVER PAGE is applicable to all samples submitted under this ASR)

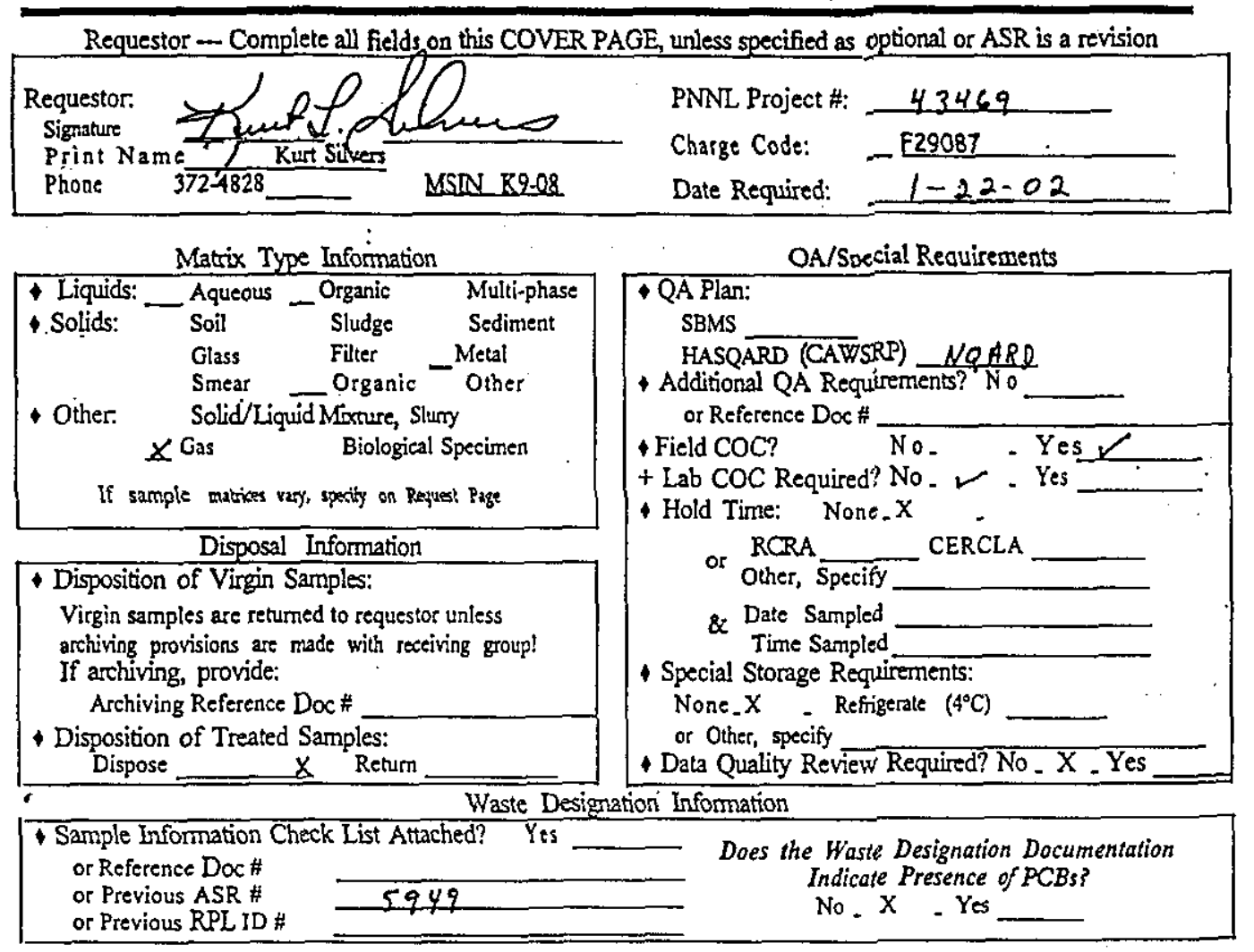

Additional or Special Instructions

Send Report To

Receiving and Login Information (to be completed by laboratory stafi)

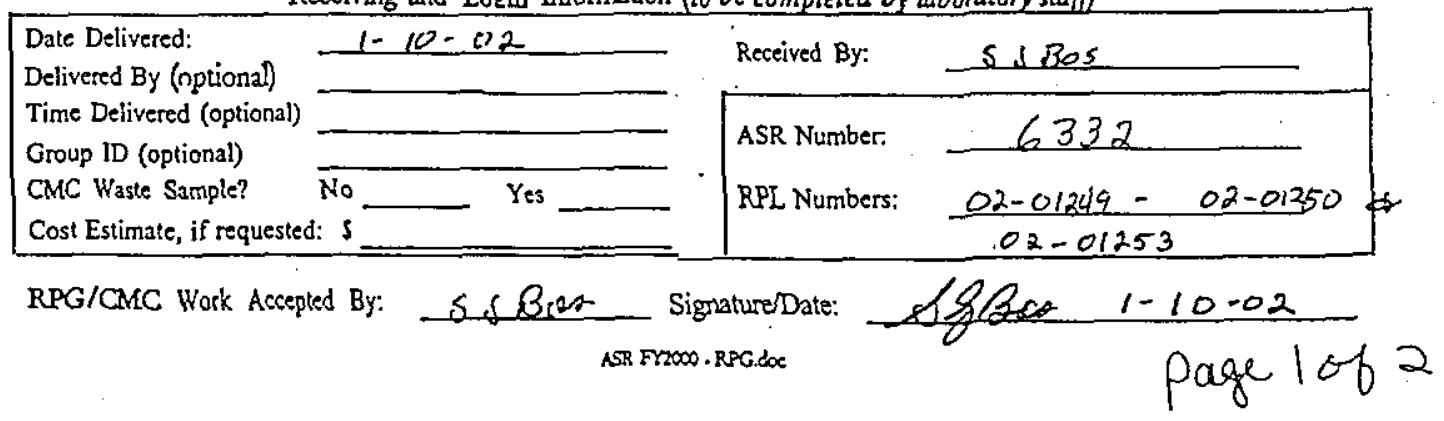




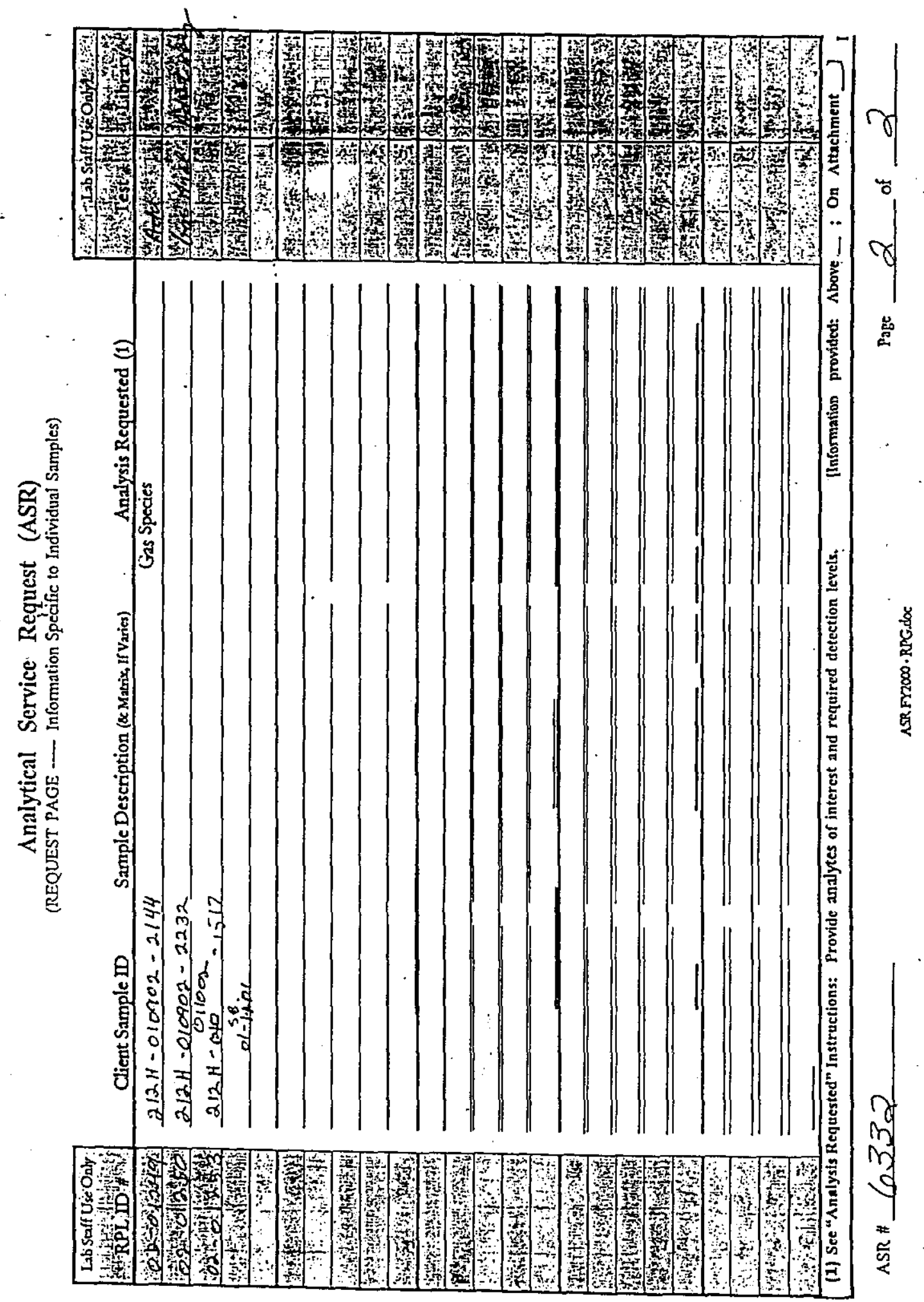




\section{Gas Species Analysis of}

Samples from the Canister Storage Building . Received by PNNL on January 10, 2002

43469-RPT05, Rev. 0

Quality Control Check

January 17, 2002

\section{Pacific Northwest National Laboratory}




\section{Pacific Northwest National Laboratory}

From: 325 Gas \& Isotopic Mass Spectrometry

Phone: (509) 376-3358 / mail slot P7-22

Date: January 07, 2002

- Subject: Air standards from Finnigan MAT - 271 Mass Spectrometer

Analytical procedure: PNNL - 98523 - 284 Rev. 0

Laboratory Record Book 56998: Page 138

Measurement and test equipment WC38625

Accepted values for the composition of air :

$\begin{array}{lc} & \text { Mole percent } \\ \text { Argon } & 0.934 \\ \text { Nitrogen } & 78.08 \\ \text { Oxygen } & 20.95\end{array}$

Analyzed Values:

Analysis Date: January 07,2002

$\begin{array}{ll}\text { Argon } & 0.938 \\ \text { Nitrogen } & 78.05 \\ \text { Oxygen } & 20.97\end{array}$

Oxygen $\quad 20.97$

Analyzed Values:

$\begin{array}{lc}\text { Aralysis Date: } & \text { January } 07,2002 \\ & \text { Mole percent } \\ \text { Argon } & 0.937 \\ \text { Nitrogen } & 77.92 \\ \text { Oxygen } & 21.11\end{array}$

Instrument Background:

Background analyses are run daily prior to sample analyses. Trace amounts of hydrogen and/or water in the 0.1 to 0.2 millivolt range were the only species detected. The background spectra is subtracted from each sample spectra. 


\section{Gas Species Analysis of \\ Samples from the Canister Storage Building . Received by PNNL on January 10, 2002 \\ 43469-RPT05, Rev. 0 \\ Raw Instrument Data from Gas Analysis}

January 17, 2002

Pacific Northwest National Laboratory 


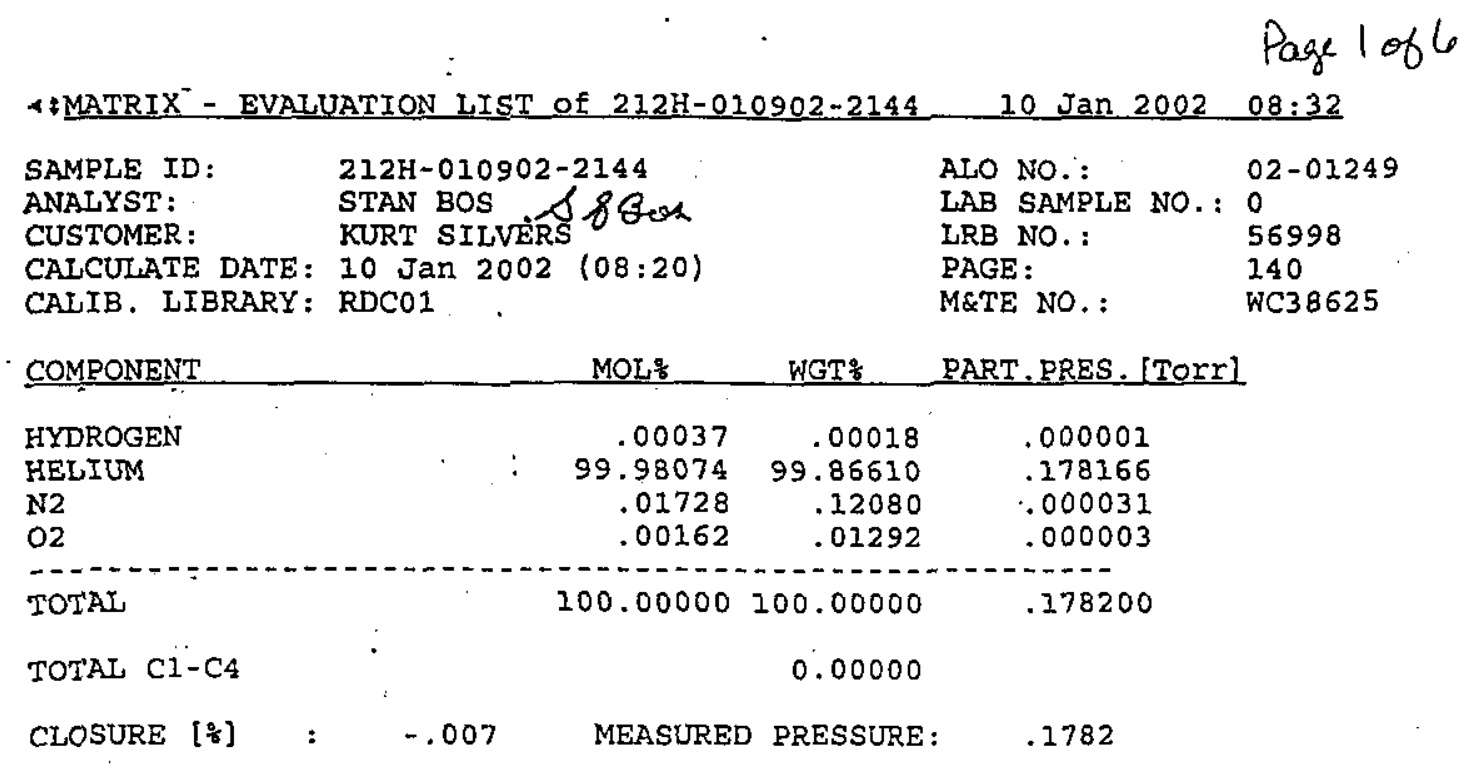

Reviewed By: P.R. Date: 1-10.02 
Spent Nuclear Fuel Project Canister Storage Building

Multi-Canister Overpack Sampling System Validation (OCRWM)

4 4PECTR UM LIS T :SAMPLE SPECTRUM 10 Jan 2002 08:31

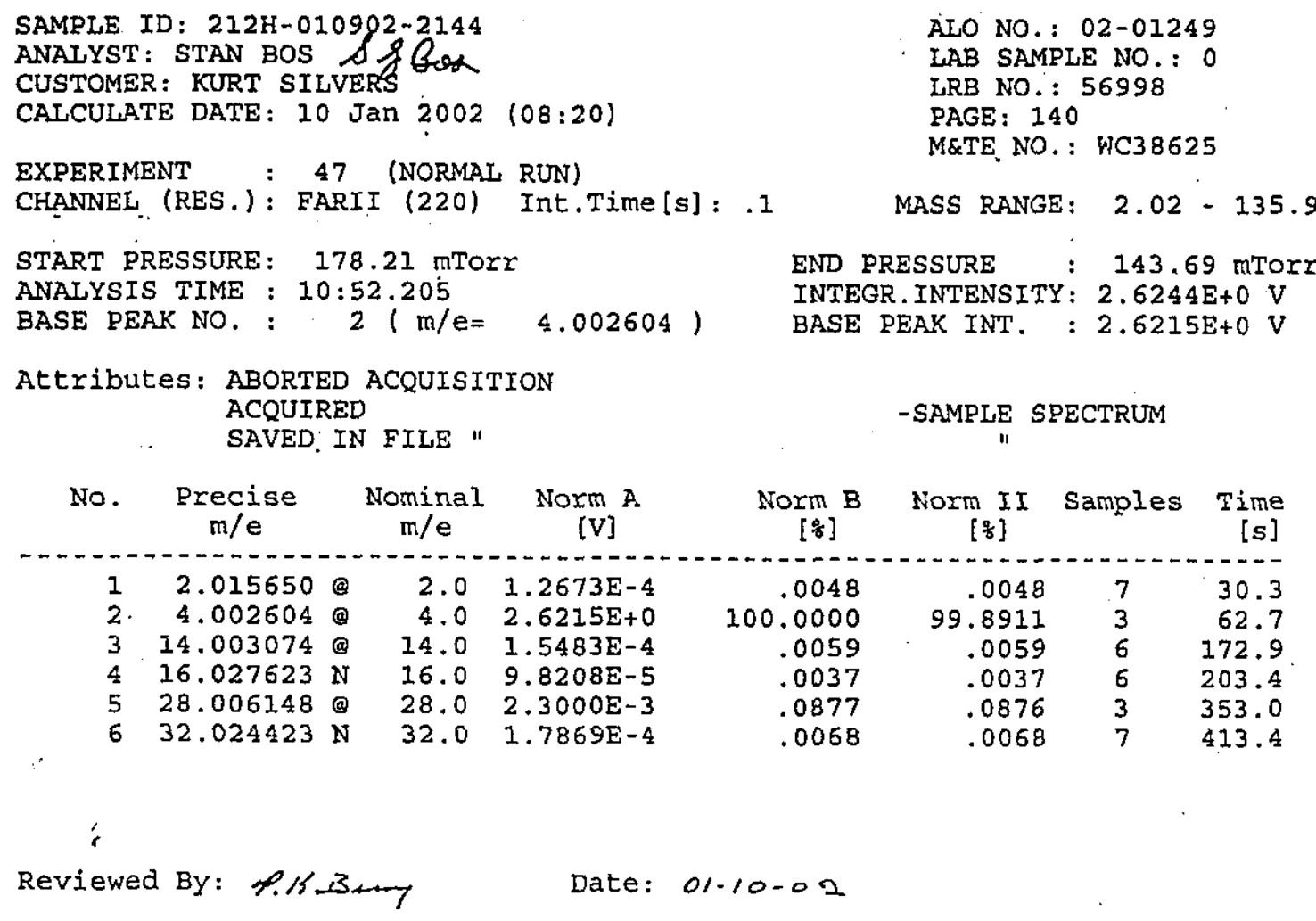




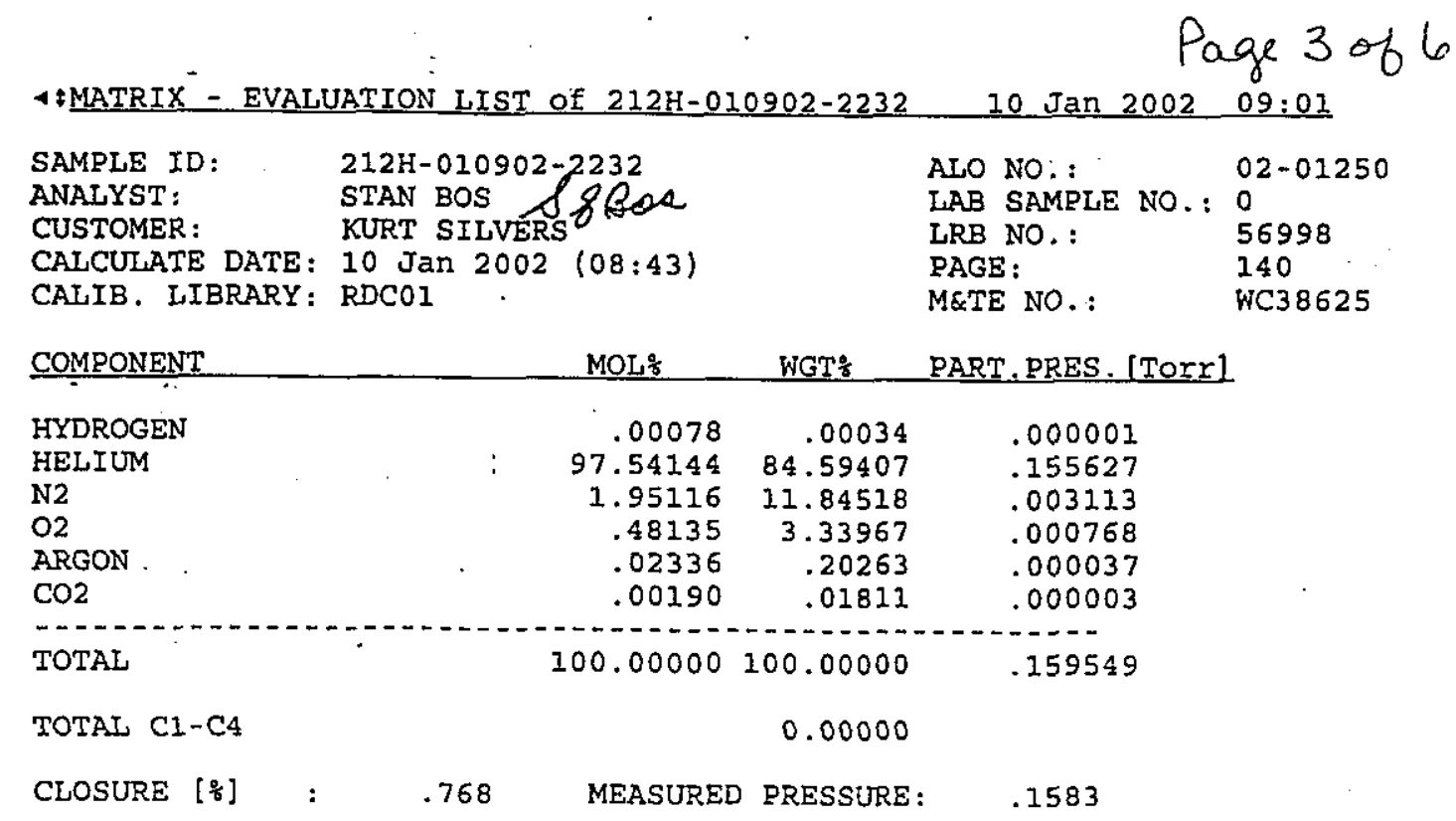

Reviewed By: P.K.Rmy

Date: $1-10 \cdot 02$ 


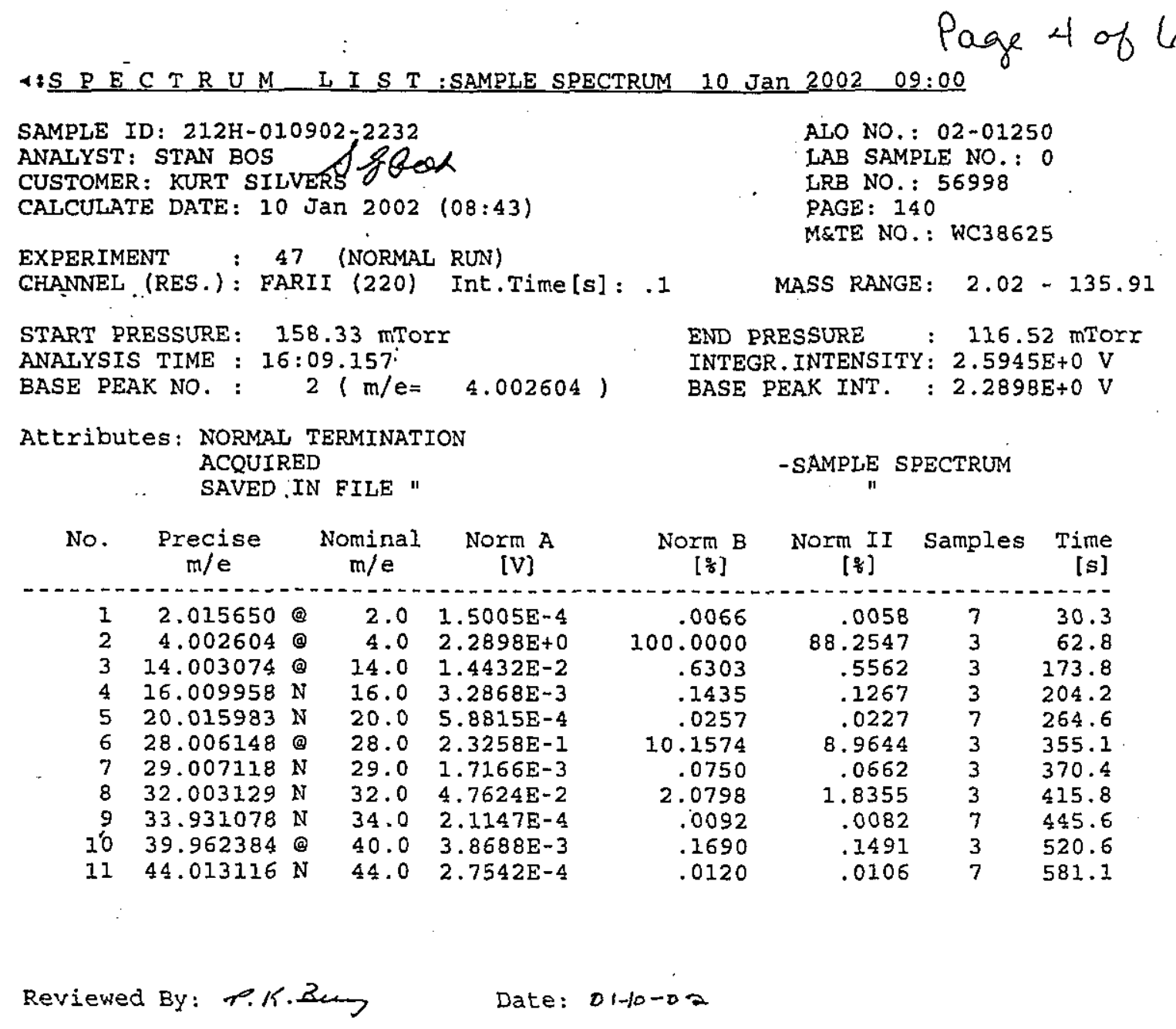




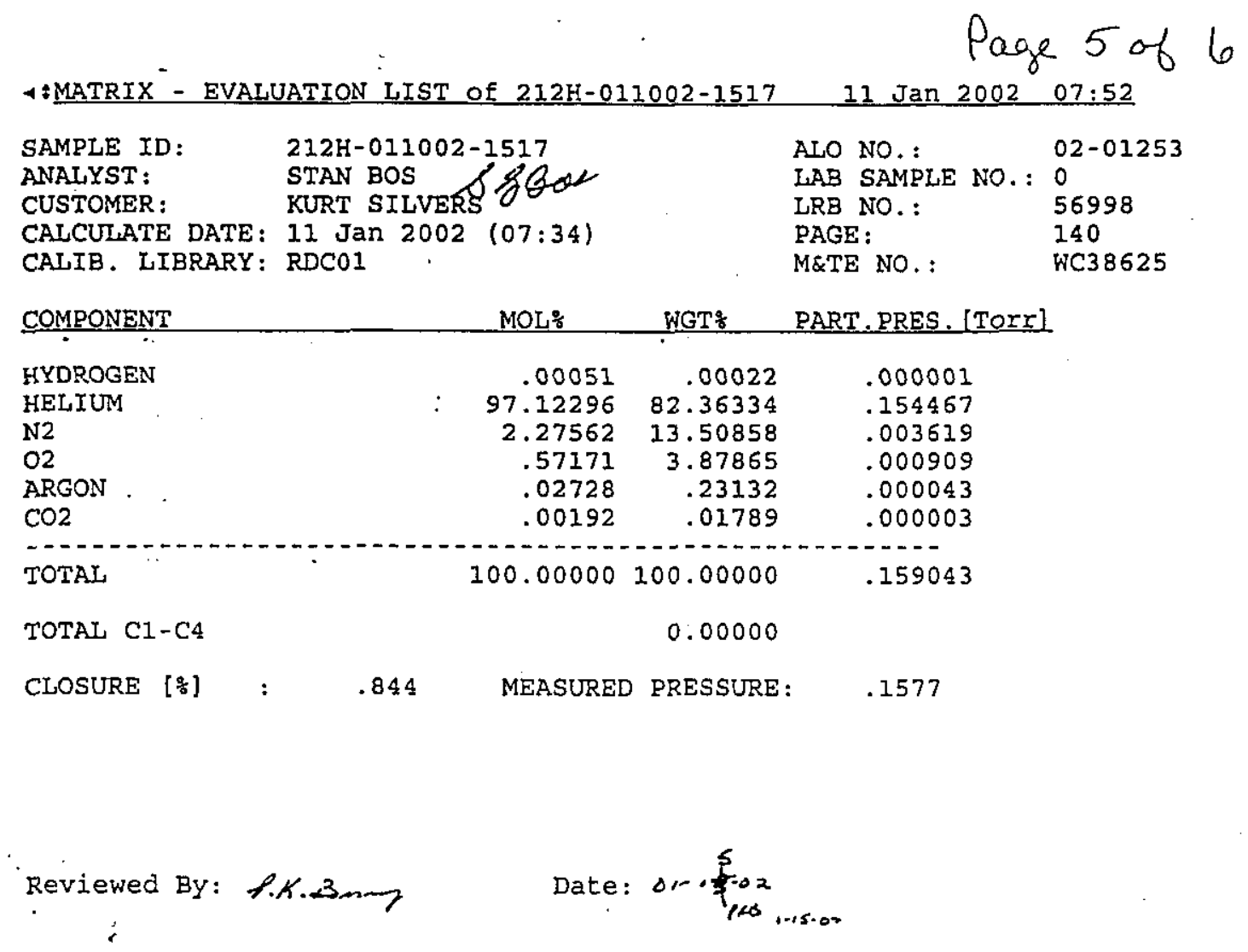


Spent Nuclear Fuel Project Canister Storage Building

Multi-Canister Overpack Sampling System Validation (OCRWM)

SNF-10618

Rev. 0

Page 6 of 6

4IS PECTTRUM LIS T :SAMPLE SPECTRUM 11 Jan 2002 07:51

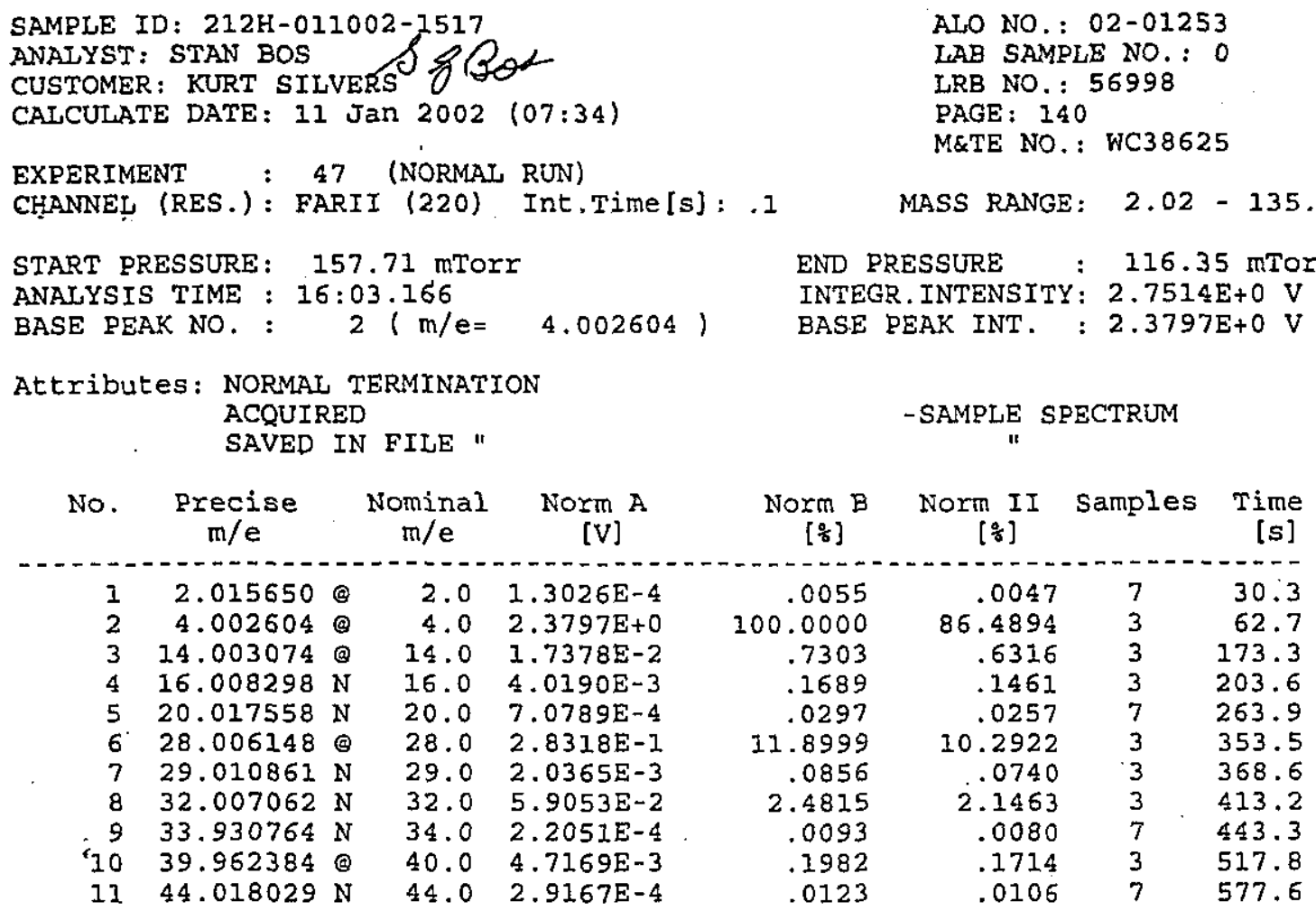

Reviewed By:P.K.B.S Date: 61-15-0n 